\title{
As espécies de Pera (Euphorbiaceae s.s) na Amazônia brasileira
}

\author{
Species of Pera (Euphorbiaceae s.s.) in Brazilian Amazon
}

\author{
Narcisio Costa Bigio $^{1,3}$ \& Ricardo S. Secco ${ }^{2}$
}

\begin{abstract}
Resumo
Pera Mutis é um gênero neotropical, com aproximadamente 30 espécies e centro de diversidade localizado na Bacia Amazônica. São árvores ou arbustos, dióicos ou raramente monóicos, que apresentam uma bráctea globosa que às vezes é confundida com botões florais. A última revisão do gênero foi realizada em 1919, sendo que muitas espécies foram descritas desde então. Este trabalho objetiva realizar um estudo taxonômico das espécies de Pera que ocorrem na Amazônia brasileira, discutindo a posição do gênero como parte de um táxon autônomo (Peraceae) ou como membro das Euphorbiaceae s.s. Foram encontradas 13 espécies na Amazônia brasileira: P. anisotricha Müll. Arg., P. bicolor (Klotzsch) Müll. Arg., P. benensis Ruby, P. coccinea (Benth.) Müll. Arg., P. decipiens Müll. Arg., P. distichophylla (Mart.) Baill., P. eiteniorum Bigio \& Secco, P. glabrata (Schott) Baill., P. heteranthera (Schranck) I.M. Johnst, P. manausensis Bigio \& Secco, P. membranacea Leal, P. tomentosa (Benth.) Müll. Arg. e P. pulchrifolia Ducke. Destas, três são novas ocorrências para a Amazônia brasileira, oito táxons foram considerados como novos sinônimos e novos lectótipos foram designados. Um histórico taxônomico do gênero, informações sobre sua morfologia, bem como descrições, chave de identificação, ilustrações e informações sobre a biologia de cada espécie são fornecidos.
\end{abstract}

Palavras-chave: Peraceae, Acalyphoideae, flora amazônica.

\begin{abstract}
Pera Mutis is an endemic genus from the Neotropics, with about 30 species and diversity center located in the Amazon. These species are trees or shrubs, dioecious or rarely monoicous, having globose bracts that are sometimes confused with floral buds. The last revision of this genus was in 1919, and many species have been described since then. This work aims to carry out a taxonomic study of Pera species that occur in the Brazilian Amazon and discussing the position of genera as part of an autonomous taxon (Peraceae) or if a member of the Euphorbiaceae s.s. Thirteen species in the Brazilian Amazon were found: Pera anisotricha Müll. Arg., P. bicolor (Klotzsch) Müll. Arg., P. benensis Ruby, P. coccinea (Benth.) Müll. Arg., P. decipiens Müll. Arg., P. distichophylla (Mart.) Baill., P. eiteniorum Bigio \& Secco, P. glabrata (Schott) Baill., P. heteranthera (Schranck) I. M. Johnst, Pera manausensis Bigio \& Secco P. membranacea Leal, P. tomentosa (Benth.) Müll. Arg., P. pulchrifolia Ducke. From these species, three are new records for the Brazilian Amazon. Eight taxa were considered to be new synonyms and new lectotypes were designated. Data on the history of the genus, and on morphology and biology, as well as descriptions, identification keys, and illustrations of the species are presented.
\end{abstract} Key words: Peraceae, Acalyphoideae, Amazonian flora.

\section{Introdução}

Pera Mutis é um gênero endêmico do neotrópico (Gordillo \& Morrone 2005), pertencente às Euphorbiaceae s.s. ou provavelmente a Peraceae, com cerca de 30 espécies (Webster 1994; Gillespie \& Armbruster 1997). Ocorre desde Cuba e América Central até o Sul do Brasil (Rio Grande do Sul).
A maior concentração das espécies de Pera está na bacia amazônica (Webster 1994). Este gênero apresenta um caráter morfológico único entre as Euphorbiaceae, que é o pseudanto unissexuado (inflorescência cimosa) com flores reduzidas, envolvidas por uma bráctea involucral vistosa (verde, amarela, creme, branca ou, às vezes, vermelha), perfumada e mais ou menos globosa.

\footnotetext{
${ }^{1}$ Universidade Federal de Rondônia, Depto Biologia, Campus BR 364, km 9,5, Sentido Acre, CEP 78900-000, Porto Velho, RO, Brasil.

${ }^{2}$ Museu Paraense Emilio Goeldi, Herbário, Av. Magalhães Barata 376, CEP 66040-170, Belém, PA, Brasil.

${ }^{3}$ Autor para correspondência: narcisio@gmail.com
} 
De acordo com Webster (1994), Pera está posicionado na subfamília Acalyphoideae Ascherson e incluído isoladamente na tribo Pereae Müll. Arg., posição aceita por alguns autores que trabalharam com o gênero, tais como Baillon (1858), Pax \& Hoffmann (1919), Jablonski (1967) e Webster (1994). Entretanto estudos filogenéticos utilizando sequências de DNA demonstraram que Pera e os demais gêneros próximos (Chaetocarpus Thwaites, Clutia L., Pogonophora Miers ex Benth. e Trigonopleura Hook. f.) são basais a Rafflesiaceae, mantendo Euphorbiaceae s.s. (Wurdack et al. 2005; Wurdack \& Davis 2009). De maneira a preservar as características morfológicas peculiares utilizadas na circunscrição de Rafflesiaceae, bem como o seu monofiletismo, alguns autores propuseram que Pera e gêneros próximos fossem agrupados em Peraceae (Stevens 2001; Souza \& Lorenzi 2008; Wurdack \& Davis 2009). Porém, o sistema do APG III (2009) ainda não reconhece Peraceae com uma família distinta de Euphorbiaceae.

Os principais trabalhos de caráter revisional tratando Pera são os de Müller (1866) e Pax \& Hoffmann (1919), que estudaram as espécies ocorrentes no neotrópico, enquanto Müller (1874) tratou as espécies de Pera ocorrentes no Brasil. Entretanto, todos esses três estudos necessitam de atualização, pois apresentam chaves difíceis de serem utilizadas para as seções e espécies, além do que outras espécies foram descritas após a publicação dessas obras. Müller (1874) citou 14 espécies de Pera para o Brasil, sendo quatro para a Amazônia. Outros autores, como Leal (1951) e Jablonski (1967), forneceram contribuições ao conhecimento de Pera, o primeiro propondo espécies novas e o segundo informando sobre as espécies da Guiana. Silva Alves (1993) propôs alguns sinônimos e lectótipos, informando a distribuição geográfica de algumas espécies antilhanas e sul-americanas.

Os trabalhos mais recentes sobre Pera continuam sendo os de Gillespie \& Ambruster (1997), tratando cinco espécies das Guianas e de Gillespie (1999), abordando sucintamente seis espécies da Flora da Guiana Venezuelana.

Constata-se que Pera não foi objeto de nenhuma revisão atualizada, o que justifica o presente estudo. Além disso, trata-se de um gênero estritamente neotropical, cujo centro de divesidade está na bacia amazônica (Webster 1994).

Desta forma, tem-se por objetivo realizar um estudo taxonômico sobre as espécies de Pera que ocorrem na Amazônia brasileira, atualizando as identificações, descrições e distribuição geográfica, bem como discutindo a posição do gênero como parte de um táxon autônomo (Peraceae) ou se um membro das Euphorbiaceae s.s.

\section{Material e Métodos}

Foram estudadas as exsicatas depositadas nos herbários CEN, IAN, INPA, UB, UFMT, MG, RB, SP e R, bem como amostras de plantas coletadas pelo autor na Ilha de Maiandeua, Pará e Reserva Ducke, Amazonas. Para auxiliar nas identificações, foram consultados tipos e fotos de tipos, procedentes dos seguintes acervos: BR, F, IAN, G, G-DC, K, M, MG, NY, RB, bem como diagnoses e descrições existentes na literatura.

Os espécimes foram dissecados, mensurados e ilustrados. Para a padronização da nomenclatura das formas e dos tipos de indumento, tricomas, folhas, inflorescências, flores, frutos e sementes, tomou-se como base os trabalhos de Radford et al. (1974), Rizzini (1977), Inamdar \& Gangadhara (1977), Webster et al. (1996) e Barroso et al. (1999).

Devido a limitação de espaço a lista de material examinado foi reduzida a pelo menos a uma localidade em que a espécie ocorra, priorizando-se os espécimes que tivessem maior quantidade de duplicatas analisados.

As espécies estão apresentadas em ordem alfabética de acordo com a seção e dentro de cada uma destas, novamente em ordem alfabética.

\section{Resultados e Discussão}

Histórico de Pera, com ênfase

nas espécies ocorrentes

na Amazônia brasileira

Pera foi estabelecido por Mutis (1784), ao descrever Pera arborea Mutis, baseado na coleção Mutis s $/$, coletada em Mariquita (Colômbia), na expedição intitulada "Real Expedición Botánica del Nuevo Reino de Granada". Primeiramente, o nome do gênero seria Sparmannia, em homenagem ao botânico Anders Sparmann (Hernandez Alba 1957-58), porém esta denominação não pode ser utilizada, uma vez que Linnaeus f. já havia designado um gênero de Tiliaceae com o nome daquele mesmo botânico. Por isso, o botânico Peter Jonas Bergius, responsável por fazer a publicação da espécie de Mutis, substituiu o nome Sparmannia por Pera, devido ao aspecto saciforme dos invólucros das inflorescências (Hernandez Alba 1983; Cardiel 1991). 
Schreber (1791) sinonimizou Pera como Perula, o que não foi aceito por nenhum dos taxonomistas que o sucederam, sendo aceito o basiônimo Pera arborea Mutis.

Frei Leandro do Sacramento (1821) descreveu o gênero Spixia, baseado na coleção Leandro 2, mas Schranck (1821) no mesmo volume da revista "Denkschriften der Königlichen Academie der Wissenschaften zu München", descreveu Spixia heteranthera Schranck baseando-se na mesma coleção. Martius (1841) propôs um novo epíteto para $S$. heteranthera, passando a denominá-la $S$. leandri, afirmando que Schrank havia denominado erroneamente a espécie. Baillon (1858) considerou Spixia como sinônimo de Pera, passando S. leandri para Pera leandri. Johnston (1923) fez uma nova combinação a partir do basiônimo $S$. heteranthera, estabelecendo $P$. heteranthera.

Martius (1841) descreveu Spixia distichophylla, com base na coleção Martius 2786, coletada em Manaus. Klotzsch (1841) descreveu Schismatopera, caracterizado por um invólucro unibracteolado, citando duas espécies para tal gênero: $S$. martiana, baseada na coleção Poeppig 2497, coletada no Amazonas, e $S$. distichophylla, proposta como nova combinação de Spixia distichophylla. Klotzsch (1843) sinonimizou Schimatopera martiniana a Schimatopera distichophylla. Baillon (1858) propôs Schismatopera como sinônimo de Pera.

Klotzsch (1841) apenas citou, sem descrever, três espécies brasileiras de Spixia: $S$. barbinervis Klotzch, S. leandri Mart. e S. grandiflora Mart., portanto todas nomina nudum. Müller (1874) utilizou a coleção Martius $s / n$ e descreveu Pera anisotricha, propondo S. barbinervis como sinônimo de $P$. anisotricha. Ule (1908) descreveu P. bahiana, a partir da coleção Ule 6964, coletada em Maracás. Pax \& Hoffmann (1919) fizeram uma nova combinação, a partir de $S$. barbinervis, estabelecendo $P$. barbinervis, e considerando $P$. bahiana como sinônimo desta, porém o nome correto que deve ser usado é $P$. anisotricha.

Klotzsch (1843) descreveu Peridium bicolor, coletada na Guiana. Müller (1866) a transferiu para Pera, estabelecendo a combinação Pera bicolor (Klotzch) Müll. Arg.

Bentham (1854) fez um breve comentário sobre Peridium schomburgkiana, que foi identificada em material depositado em herbário por Klotzsch, a partir das coleções Rich Schomburgk 901, 905 e Rob Schomburgk II 580, coletadas na Guiana Venezuelana e Monte Roraima. Entretanto,
Müller (1866) foi quem descreveu, já fazendo uma nova combinação, estabelecendo Pera schomburgkiana. Lanjouw (1931) considerou Pera schomburgkiana como sinônimo de Pera bicolor.

Bentham (1854) descreveu Peridium coccineum, baseado na coleção de Spruce 488, que Müller (1866) considerou como Pera coccinea (Benth.) Müll. Arg. Bentham (1854) descreveu também Peridium bicolor var. nitidum, a partir das coleções Rob. Schomburgk 685 e 686, Rich Schomburgk 1070 e 1071 e Spruce $s / n$. Müller (1865) utilizando as coleções de Rich Schomburgk 1070 e 1071, propôs Peridium decipiens. Müller (1866) fez uma nova combinação com Peridium decipiens, estabelecendo Pera decipiens. Além disso, Bentham (1854) descreveu Peridium bicolor var. tomentosum, baseado nas coleções Schomburgki 114 e Spruce 1820. Baillon (1865) citou Pera cinerea, baseado nas coleções Spruce 1820, 3219, Poeppig 2640, mas não a descreveu, sendo portanto um nome invalidamente publicado. Müller (1866) fez uma nova combinação, a partir de Peridium bicolor var. tomentosum, estabelecendo Pera tomentosa, também colocando Pera cinerea como um sinônimo de $P$. tomentosa. Jablonski (1967) propôs uma nova combinação, com base em Peridium bicolor var. nitidum, estabelecendo Pera nitida, também propondo Pera decipiens como sinônimo de Pera nitida, citando todas as coleções utilizadas por Bentham (1854) para descrever $P$. nitida. Gillespie (1993) sugeriu que $P$. nitida fosse rejeitada em favor de $P$. decipiens, pois esta fora descrita primeiro, com base no mesmo tipo.

Baillon (1858) considerou Peridium como sinônimo de Pera. Baillon (1865) descreveu Pera klotzschiana, com base na coleção Selow $s / n$, e colocou Peridium glabratum Schott como sinônimo desta espécie. Glaziou (1912) descreveu duas variedades para o Rio de Janeiro, Pera glabrata var. parvifolia, com base na coleção Glaziou 8327, e P. glabrata var. petroliana, através da coleção Glaziou 11 16. Pax \& Hoffmann (1919) consideraram Peridium obtusifolium, P. ovale, Pera glabrata var. parvifolia e P. glabrata var. petroliana como sinônimos de Pera glabrata, bem como Peridium oblongifolium como sinônimo de Pera ferruginea. Jablonski (1967) considerou Pera ferruginea como sinônimo de $P$. glabrata.

Baillon (1865) descreveu Pera citriodora, baseado na coleção Spruce 3686, coletada em São Carlos, Alto rio Negro, e neste trabalho foi considerado como sinônimo de Pera bicolor. 
Rusby (1920) descreveu Pera benensis, a partir da coleção Rusby 2646, procedente da Bolívia, sendo esta a segunda espécie com folhas opostas descritas para o gênero.

Ducke (1937) descreveu Pera pulchrifolia, baseado na coleção de Ducke s/ $n$ e 241, procedentes de Manaus.

Leal (1951) descreveu Pera membranacea, baseando-se na coleção Ducke $s / n$, procedente do rio Tapajós, e Pera frutescences, com base na coleção Ducke s/n, coletada em Mojú, no Pará., Neste trabalho, Pera frutescences foi sinonimizada em Pera heteranthera. Leal (1951) descreveu também Pera incisa, tomando por base a coleção Kuhlmann 1890, procedente do rio Tapajós, e que nestre trabalho foi considerada como sinônimo de Pera coccinea.

Bigio \& Secco (2010) propuseram Pera manausensis, uma espécie endêmica de Manaus, conhecida somente por 2 espécimes.

Bigio \& Secco (2011) publicaram outra espécie, Pera eiteniorum, que ocorre na fitoregião do sudoeste da Amazônia (Prance 1994).

\section{A posição taxonômica de Pera}

Pera sempre foi tratado isoladamente em Euphorbiaceae, ora como gênero, ora como uma subtribo, tribo, subfamília ou família. A presença do invólucro na inflorescência é um caráter diferencial, que destaca Pera dos demais gêneros em Euphorbiaceae.

Klotzsch (1843) estabeleceu a tribo Prosopidoclineae, agrupando os gêneros Spixia, Schismatopera, Peridium e Pera. Mais tarde, Baillon (1858) mudou o nome de tal tribo para Perideae, por achá-lo inconveniente, tratando a tribo como monogenérica, sinonimizando todos os gêneros agrupados por Klotzsch em Perideae.

Klotzsch (1859) sugeriu a Ordem Peraceae, para agrupar todas as espécies da tribo Prosopidoclineae, dentro da classe Tricoccae. Müller $(1866,1874)$ considerou a classe Tricoccae como (família) Euphorbiaceae e a ordem Peraceae como subtribo Pereae. Pax \& Hoffmann (1919) posicionaram Pera isoladamente na tribo Pereae, próxima das tribos Dalechampieae e Acalypheae, como parte da subfamília Crotonoideae. Pax \& Hoffmann (1919), Hutchinson (1969) e Webster $(1975,1987,1994)$ mantiveram Pera como gênero único na tribo Pereae. Airy Shaw (1973) recolocou Pera em nível de família (Peraceae), concordando com o conceito de Klotzsch (1859). Radcliffe-
Smith (1987) manteve Peraceae, apresentando pela primeira vez uma justificativa para tal classificação, ou seja, as inflorescências reduzidas, ausência de disco floral e fruto esquizocárpico. Webster (1994) considerou Pera como um dos grupos basais da subfamília Acalyphoideae, posicionando-o entre as tribos Chaetocarpeae e Cheiloseae.

No trabalho de Wurdack et al. (2005), que é o mais recente sobre a classificação das Euphorbiaceae, utilizando métodos moleculares, verifica-se que os autores não concordam com a separação de Pera em uma família isolada, propondo Pera como membro da subfamília Peroideae, das Euphorbiaceae, ao lado de mais 4 gêneros: Clutia, Chaetocharpus, Trigonopleura e Pogonophora. Stevens (2001) e Souza \& Lorenzi (2008), baseados no sistema APG II (2003), concordaram que Pera pertença às Peraceae, mas não isoladamente, e sim com os demais quatro gêneros considerados por Wurdack et al. (2005). Isto seria justificado pelo fato de características moleculares indicarem que Rafflesiaceae estaria incluída entre as Peroideae e as demais Euphorbiaceae (sensu Wurdack 2005), que formariam um grupo polifilético. Porém, o sistema do APG III (2009) afirma que ainda são necessários mais estudos para comprovar o posicionamento de Rafflesiaceae em relação à Euphorbiaceae.

A presença de um óvulo por lóculo no ovário, estaminódio e pistilódio, bem como flores díclinas e redução da inflorescência, assemelhando-se a uma flor isolada, são algumas das características que agrupam Pera às Euphorbiaceae, subfamília Acalyphoideae. Os estudos de anatomia da madeira de Pera, segundo Hayden \& Hayden (2000), não mostraram diferenças significativas que justificassem a segregação do gênero em família independente ou subfamília.

Outros aspectos importantes em Pera e que o destacam entre as demais Euphorbiaceae são os seguintes: o invólucro da inflorescência, que protege as flores, e a deiscência dos frutos, através da qual as valvas permanecem presas ao pedicelo, sendo que a columela se divide em três partes. Nas demais Euphorbiaceae, durante a deiscência dos frutos as valvas permanecem presas à columela, que se mantém como uma unidade sólida, não sofrendo divisão (Radcliffe-Smith 1987). Além disso, Punt (1962) aponta um único tipo de pólen para o gênero (tipo Pera), enquanto Nowicke et al. $(1998,2002)$ reconhecem três tipos (tipos Pera distichophylla, P. arborea e P. parvifolia) para a tribo Pereae. Todas essas características são utilizadas como 
justificativas para a separação de Pera em uma família independente ou em uma subfamília das Euphorbiaceae.

Apesar de posicionar Pera dentro da subfamília Acalyphoideae, Webster (1994) aponta Clutia, Pogonophora, Chaetocharpus e Trigonopleura como ancestrais daquele gênero, da mesma forma que Wurdack et al. (2005). Tokuoka \& Tobe (2003) demonstraram que Clutia, Chaetocharpus, Trigonopleura e Pera deveriam ser tratados separadamente de Acalyphoideade, por apresentarem sementes testais, concordando com os dados de Wurdack et al. (2005).

Wurdack \& Davis (2009) propuseram a elevação de Peroideae ao status de família (Peraceae), conceito este ainda em discussão.

Nesse trabalho, aceita-se a proposta de Wurdack et al. (2005), que consideram Pera como uma subfamília (Peroideae) das Euphorbiaceae. Os dados moleculares e a árvore filogenética apresentada pelos referidos autores demonstram que Pera e Peroideae formam um grupo basal monofilético das Euphorbiaceae. Destaca-se que o no Projeto Lista da Flora do Brasil (2010) o gênero Pera foi incluído em Peraceae, seguindo APG II (2003), Stevens (2001) e Souza \& Lorenzi (2008).

\section{Classificação infragenérica}

Pera apresenta-se dividido em seis seções, segundo a classificação de Pax \& Hoffmann (1919), a saber: Pera sect. Diplopera, Pera sect. Perula, Pera sect. Spixia, Pera sect. Schismatopera, Pera sect. Neopera e Pera sect. Peridium. Dessas seis seções, somente quatro ocorrem na Amazônia, e, provavelmente, sejam as únicas do gênero, e aceitas no presente trabalho, já que Pera heterodoxa Müll. Arg. (Pera sect. Diplopera) é um sinônimo de Pera distichophylla (Pera sect. Schismatopera) e Pera arborea (Pera sect. Perula) deve pertencer à Pera sect. Spixia.

Distribuição geográfica de Pera, com ênfase na Amazônia brasileira

Pera tem ocorrência restrita ao Novo Mundo, ao contrário dos gêneros que lhe são próximos filogeneticamente, tais como Clutia (da África e Ásia), Pogonophora (da África e América), Chaetocharpus (da Ásia, África e América) e Trigonopleura (da Ásia) (Webster 1994; Wurdack et al. 2005). Isso talvez demonstre que Pera deva ser o mais derivado entre esses cinco gêneros (Wurdack et al. 2005).
Na região amazônica ocorrem 13, das 30 espécies existentes no neotrópico, o que demonstra ser uma região com ampla distribuição do gênero, já que as demais espécies ausentes na Amazônia parecem ter uma distribuição bem restrita. $\mathrm{O}$ estado do Amazonas é o que tem maior número de representantes, com sete espécies, sendo que cinco ocorrem na cidade de Manaus, provavelmente por esse estado e a cidade serem os que mais apresentam coletas na região amazônica (Nelson et al. 1990).

Analisando-se as espécies de acordo com as seções nas quais estão posicionadas, verificou-se a seguinte distribuição:

I. Pera sect. Neopera: apresenta cinco espécies: Pera bicolor, $P$. coccinea, $P$. decipiens, $P$. manausensis, $P$. tomentosa e $P$. pulchrifolia. Todas restritas à Amazônia.

II. Pera sect. Pera: apresenta duas espécies com distribuição ampla no Brasil: Pera anisotricha e $P$. heteranthera, e duas restritas à Amazônia brasileira: $P$. membranacea e $P$. eiteniorum.

III. Pera sect. Peridium, com duas espécies: P. glabrata, que se distribui em quase toda a América do Sul, e P. benensis, que ocorre no sudoeste da Amazônia.

IV. Pera sect. Schismatopera: apresenta uma espécie restrita à Amazônia: $P$. distichophylla.

Com base no trabalho de Prance (1994), as espécies podem ser agrupadas de acordo com sua distribuição geográfica:

1. Espécies amplamente distribuídas: são aqui consideradas as espécies que ocorrem em mais de um bioma.

Pera glabrata é a espécie mais amplamente distribuída do gênero, com ocorrência desde o sul do Brasil até o norte da Venezuela, sendo que na Amazônia apresenta uma distribuição disjunta nas áreas da costa atlântica, Roraima-Manaus, noroeste do Alto rio Negro e sudoeste da Amazônia. Pera heteranthera concentra-se no Sudeste do Brasil, sendo que da Amazônia só se conhecem duas coleções procedentes da costa atlântica do Estado do Pará. Pera anisotricha apresenta distribuição disjunta na Amazônia, sendo encontrada nas regiões da costa atlântica (Jari-Trombetas e XinguMadeira). Pera distichophylla é aqui incluída por ter uma ocorrência no estado do Ceará, e por distribuir-se em praticamente toda a Amazônia.

2. Espécies ocorrentes exclusivamente na Amazônia: aqui são consideradas as espécies que ocorrem na Amazônia brasileira e extra-brasileira. 
Pera benensis, com populações no sudoeste da Amazônia. Pera tomentosa, com registro no sudoeste da Amazônia, noroeste do Alto rio Negro, SolimõesAmazonas e Manaus. Pera decipiens, ocorrendo praticamente em toda a Amazônia, e Pera bicolor, distribuída na costa atlântica, Roraima, Manaus, noroeste do Alto rio Negro e sudoeste da Amazônia.

\section{Espécies com distribuição restrita à Amazônia} brasileira: diferente das anteriores, as espécies aqui apresentadas ocorrem somente na Amazônia brasileira Pera coccinea é uma espécie que ocorre em maior número de regiões, entre elas, Jari-Trombetas, Xingu-Madeira e sudoeste. Pera eiteniorum ocorre apenas no sudoeste da Amazônia, e P. membranacea no Xingu-Madeira.

4. Espécies endêmicas: inclui apenas duas espécies que ocorrem em uma localidade.

Aqui podem ser citadas apenas duas espécies: P. pulchrifolia e P. mamausensis, ambas encontradas em Manaus.

\section{Aspectos morfológicos}

\section{Hábito}

A maioria das espécies de Pera apresenta o hábito arbustivo, sendo que aquelas encontradas na Amazônia brasileira podem ser árvores, arvoretas ou arbustos, em geral com até $15 \mathrm{~m}$ de altura e 30 $\mathrm{cm}$ de diâmetro (DAP). O estudo de Hayden \& Hayden (2000), tratando da anatomia da madeira de Pera, demonstrou que os vasos apresentam parede grossa com tilose esclerificada; fibras libriformes; $\mathrm{o}$ parênquima axial organizado em bandas tangencias, a maioria com 1-3 células; cristais romboidais/ prismáticos no parênquima axial e raios unisseriados.

\section{Indumento}

Todas as espécies de Pera estudadas apresentam algum tipo de indumento, e este é um caráter forte para identificá-las. Na Amazônia ocorrem espécies com os seguintes tipos de indumento: esparso, denso, tomentoso, seríceo e barbado (Inamdar \& Gangadhara 1977; Radford et al. 1974). Os tricomas que formam o indumento são de 3 tipos principais: simples, estrelados e lepidotos. Os dois últimos podem apresentar variações, tais como: estipitadoestrelados, estrelado-lepidotos, lepidoto-estrelados e lepidoto-radiados (Inamdar \& Gangadhara 1977; Radford et al. 1974). Na maioria das vezes, o tipo de indumento encontrado na folha é o mesmo para o restante da planta, somente Pera manausensis não segue este padrão, já que apresenta tricomas lepidoto-radiados nas folhas e tricomas estrelados no ovário. Pelo tipo de tricoma encontrado nas folhas pode-se separar as espécies em três grupos: I. Espécie com tricomas simples (P. distichophylla); II. Espécies com tricomas lepidotos e suas variações $(P$. glabrata, P. decipiens, P. benensis, Pera manausensis e $P$. coccinea); III. Espécies com tricomas estrelados e suas variações ( $P$. anisotricha, $P$. eiteniorum, $P$. heteranthera, P. membranacea, P. pulchrifolia, $P$. bicolor e P. tomentosa).

\section{Filotaxia e folhas}

É possível encontrar dois padrões de filotaxia em Pera: folhas alternas e folhas opostas. O mais comum é encontrar espécies com folhas alternas, mas há três espécies com folhas opostas: Pera oppositifolia Griseb., endêmica de Cuba, $P$. benensis e Pera pulchrifolia, que são encontradas na Amazônia brasileira. As folhas opostas parecem ter surgido em dois momentos distintos durante a evolução do grupo, considerando-se que essas três espécies pertencem à duas seções diferentes. As folhas não apresentam variações morfológicas significativas. Podem ser elípticas a oblongas, simples, com a margem inteira, base cuneada a obtusa, o ápice arredondado a acuminado e pecíolo canaliculado. Coletas de Pera glabrata apresentam as folhas com uma coloração verde brilhante na face adaxial e verde oliváceo na abaxial, o que parece ser um padrão no gênero, pois a maioria das etiquetas de herbário também contém esta informação.

\section{Inflorescência}

Pera apresenta um tipo particular de inflorescência (Fig. 1), definido como pseudanto (pseudo $=$ falsa; anthos $=$ flor) ou pseudantial (Gillespie \& Armbruster 1997), que é uma estrutura que lembra uma flor isolada (Font Quer 1953), apresentando de 3 a 4 flores dispostas em glomérulo. Nas Euphorbiaceae encontram-se outros tipos de pseudantos, conhecidos como ciátios, como por exemplo em Euphorbia L. (Weberling 1992). Em Pera e Dalechampia L. os pseudantos são caracterizados pela presença da bráctea involucral que protege as flores. Pera subg. Eupera (Croizat 1942) apresenta uma única bráctea involucral em forma de saco ou capuz, que se abre longitudinalmente na antese, podendo ficar com uma fenda frontal (em Pera sect. Peridium e Pera sect. Neopera) (Fig. 1a) ou abrir-se totalmente ao meio, deixando as flores expostas (Pera sect. Schismatopera e Pera sect. Pera) (Fig. 1b). Em Pera 

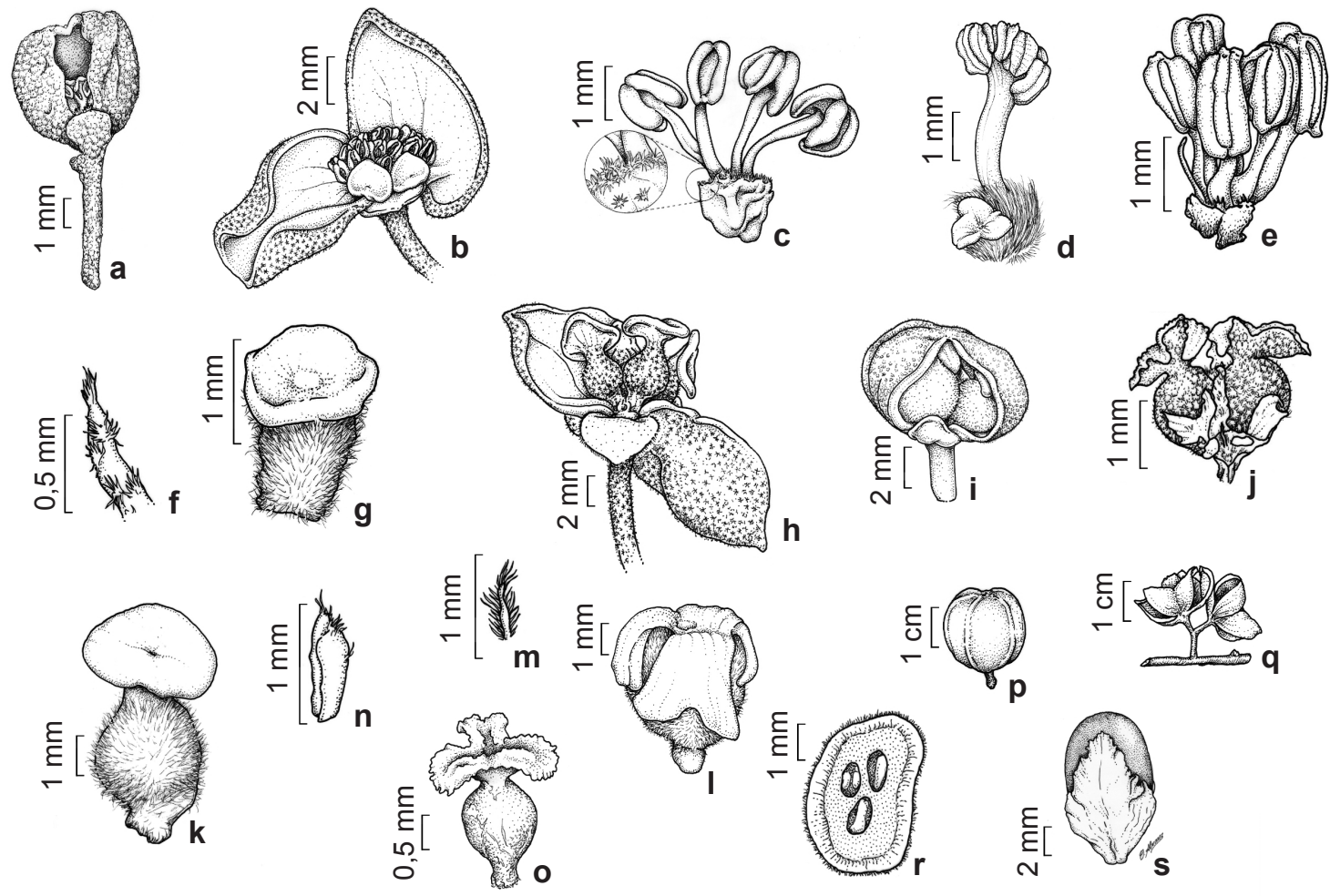

Figura 1 - Diversidade morfológica das estruturas reprodutivas em Pera - a. inflorescência estaminada na antese ( $P$. decipiens, J.M. Pires et al. 1983); b. inflorescência estaminada na antese (P. anisotricha, M. Silva et al. 2509); c. flor estaminada, cálice campanulado ( $P$. decipiens, C.A. Cid Ferreira 9587); d. flor estaminada, cálice turbinado, filetes conados formando coluna estaminal, flor pistilada imatura na base. (P. distichophylla, L. Sonkin 220); e. flor estaminada, cálice rudimentar disforme (P. benensis, G.A. Black et al. 52-15216); f. pistilódio filiforme (P. coccinea, R.M. Harley et al. 11180); g. pistilódio desenvolvido ( $P$. heteranthera, M. Clara et al. 795); h. inflorescência pistilada, invólucro aberto (P. anisotricha, M. Silva et al. 2543); i. inflorescência pistilada, abertura longitudinal na antese (P. bicolor, Dionísio $s / n-$ MG 21518); j. flores pistiladas (2) com 3 estaminódios sepalóides e 1 estaminódio filiforme (Pera coccinea, M.G. Silva et al. 4034); k. flor pistilada com estigma umbraculiforme (P. heteranthera, J.M. Pires 12555); 1. flor pistilada com estigma 3-lobado, bipartido (P. manausensis, A. Vicentini et al. 1058); m. detalhe do estaminódio filiforme (Pera coccinea, M.G. Silva et al. 4034); n. detalhe do estaminódio sepalóide (Pera cocinea, M.G. Silva et al. 4034); o. flor pistilada com estigma 3-lobado (P. glabrata, N.A. Rosa et al. 1002); p. fruto imaturo, septos marcados (P. bicolor, J.A. Silva 269); q. fruto, deiscência septífraga (P. glabrata, M.G. Silva et al. 5358); r. seção longitudinal do ovário, 3-locular (P. bicolor, Dionísio s/n-MG 21518); s. semente com carúncula (P. anisotricha, U.N. Maciel et al. 224).

Figure 1 - Morphological diversity of reproductive structures in Pera - a. staminate inflorescence with a longitudinal opening $(P$. decipiens, J.M. Pires et al. 1983); b. staminate inflorescence (P. barbinervis, M. Silva et al. 2509); c. staminate flowers, campanulate calyx. (P. decipiens, C.A. Cid Ferreira 9587); d. staminate flower, turbinate calyx, conate stamens forming a staminal column, imature pistillate flower at the base. ( $P$. distichophylla, L. Sonkin 220); e. staminate flowers, rudimentary deformed calyx (P. benensis, G.A. Black et al. 52-15216); f. filiform pistilodium (P. coccinea, R.M. Harley et al. 11180); g. mature pistilodium (P. heteranthera, M. Clara et al. 795); h. pistillate inflorescence, involucre opened at the anthesis (P. anisotricha, M. Silva et al. 2543); i. pistillate inflorescence, a longitudinal opening at anthesis ( $P$. bicolor, Dionísio $s / n-$ MG 21518); j. pistillate flowers (2) with 3 sepaloid staminodes and 1 filiform staminode (Pera coccinea, G.M. Silva et al. 4034); k. pistillate flower with an umbraculate stigma (P. heteranthera, J.M. Pires s/n 12555); 1. pistillate flower with stigma 3-lobed, twice divided (P. manausensis, A. Vicentini et al. 1058); m. detail of filiform staminodes (Pera coccinea, G.M. Silva et al. 4034); n. detail of the sepaloid staminodium (Pera coccinea, G.M. Silva et al. 4034); o. pistillate flower with stigma 3-lobed (P. glabrata, N.A. Rosa et al. 1002); p. immature fruit, marked septa (P. bicolor, A.J. Silva 269); q. fruit, dehiscence septifrage (P. glabrata, M.G. Silva et al. 5358); r. longitudinal section 3-locular ovary (P. bicolor, Dionísio $s / n-$ MG 21518); s. seed with caruncle (P. barbinervis, U.N. Maciel et al. 224). 
subg. Gymnopera, a bráctea involucral é ausente ou extremamente reduzida e este provavelmente seja um caráter derivado (Croizat 1942). Segundo Weberling (1992), esse tipo de inflorescência (pseudanto) deu origem às demais inflorescências do tipo ciático nas Euphorbiaceae, porém Gilbert (1994) discute que a provável origem dos ciáticos foram as inflorescências cimosas em dicásios. Mesmo assim, os trabalhos de Webster (1994) e Wurdack et al. (2005) demonstraram que os ciáticos são uma característica homoplástica para as Euphorbiaceae.

Os pseudantos em Pera estão localizados nas axilas das folhas, dispostos em fascículos, em diferentes quantidades, nunca isolados, e são sustentados por um pedúnculo; na base da bráctea involucral encontra-se de uma a duas brácteolas orbiculares, e às vezes essas brácteolas podem ser chamadas de brácteas. Quando ocorre somente uma bractéola (como em P. distichophylla), esta fica localizada do mesmo lado da fenda longitudinal do invólucro; se ocorrerem as duas bractéolas, estas apresentarão diferentes tamanhos e localizações, ou seja, a maior estará no lado em que se abre a fenda e a menor estará oposta à maior, sendo que, em geral, a menor tem metade do tamanho da maior.

Na grande maioria, os indivíduos são dióicos, ou seja, apresentam as inflorescências somente com flores estaminadas ou pistiladas, com exceção de $P$. distichophylla (indivíduos monóicos), cujas inflorescências contêm tanto flores pistiladas quanto estaminadas. Em coletas realizadas pelos autores, etiquetas dos herbários e no trabalho de Gillespie \& Armbruster (1997), observou-se que a bráctea involucral pode apresentar diferentes cores: verde, amarela, creme, branca ou vermelha. Provavelmente essas cores têm correlação com o tipo de polinizador. Gillespie \& Armbruster (1997) observaram a visita e coleta de pólen por abelhas nas flores de $P$. bicolor, informando que, nesta espécie, a cor da bráctea involucral é amarelada e com uma fragrância acentuada.

\section{Flores}

Como em todas as Euphorbiaceae, as flores de Pera são díclinas (Fig. 1c-e).

Nas espécies de Pera ocorrentes na Amazônia brasileira, as flores estaminadas não apresentam pétalas (apétalas), podendo exibir cálice (em Pera sect. Schismatopera, Pera sect. Pera e Pera sect. Neopera) (Fig. 1c) ou ser totalmente aclamídeas com rudimento de cálice (em Pera sect. Peridium) (Fig. 1e). $\mathrm{O}$ cálice é sempre fundido, podendo ser turbinado (em P. distichophylla, P. anisotricha, P. heteranthera, $P$. membranacea e $P$. eiteniorum), urceloado (em P. coccinea, P. tomentosa, P. decipiens e P. manausensis) ou laciniado (em P. bicolor); também é lobulado, com a base concrescida, o ápice lacerado, podendo se apresentar desde glabro a totalmente indumentado. Os estames, de três a quatro, são concrescidos, podendo ser conados apenas na base (nas seções Peridium e Neopera), até a metade do filete (na seção Pera), ou totalmente concrescidos, formando uma coluna estaminal (em P. distichophylla). As anteras são sempre rimosas, apicifixas (nas seções Peridium e Neopera) ou dorsifixas (nas seções Schismatopera e Spixia). Outra característica das flores estaminadas é o pistilódio (rudimento de flor pistilada), que pode estar presente nos indivíduos dióicos (Fig. 1f-g). Quando presente, o pistilódio pode ser filiforme (Fig. 1f), como uma estrutura única, sempre menor que as flores estaminadas, disposta no centro da inflorescência (em P. coccinea e P. glabrata); ou pistilódio mais desenvolvido (Fig. 1g), apresentando-se em quatro pistilódios muito semelhantes à flor pistilada imatura, circundando as flores estaminadas (todas as espécies de Pera sect. Pera).

As flores pistiladas são sempre quatro por inflorescência (Fig. 1h-j), aclamídeas, sendo que mostram poucas diferenças morfológicas entre as espécies. Neste caso, a principal característica para separá-las é o tipo de indumento e os tricomas do ovário. Podem ser sésseis ou pediceladas, com o ovário piriforme, lageniforme ou globoso, o estigma pode ser indiviso (Pera sect. Pera) (Fig. $1 \mathrm{k}$ ) ou trífido (Pera sect. Schismatopera, Pera sect. Peridium e Pera sect. Neopera) (Fig. 11, o). Em Pera manausensis e P. bicolor, o estigma é trífido e bipartido (Fig. 11). O ovário é trilocular, com um óvulo em cada lóculo (Fig. 1r), o que corresponde a uma das características principais das Euphorbiaceae s.s. Um caráter que auxilia na identificação das espécies é a presença ou não de estaminódios (rudimento de flores estaminadas), que podem ser de dois tipos: filiformes (Fig. 1m) e sepalóides (Fig. 1n). O estaminódio filiforme sempre está posicionado externamente às flores pistiladas. Os estaminódios sepalóides estão no centro das flores pistiladas e, como o próprio nome diz, assemelham-se às sépalas. Segundo Weberling (1992), os estaminódios em geral apresentam forma de sépalas. A partir do material analisado no presente estudo, observou-se que, no caso de Pera, provavelmente os estaminódios sepalóides tenham surgido a partir dos indivíduos monóicos, que não estavam aptos a se reproduzir 
entre si, e assim as flores estaminadas tornaramse estéreis, restando-lhes apenas as sépalas. Essa hipótese pode ser justificada pela presença dos estaminódios no centro das flores pistiladas, como por exemplo, nas espécies de Pera sect. Pera, em que as flores estaminadas estão envolvidas por quatro pistilódios bem desenvolvidos, e devem ter se originado de $P$. distichophylla (espécie com indivíduos monóicos), cujas flores estaminadas estão circundadas pelas flores pistiladas.

\section{Pólen}

Erdtman (1952) estudou os grãos de pólen de diversas famílias das Angiospermas, sendo que considerou as Euphorbiaceae como euripalina, por apresentar uma grande diferença nos tipos de pólen, porém não tratou as espécies de Pera. Punt (1962), ao estudar especificamente o pólen das Euphorbiaceae, considerou Pera com um tipo específico de pólen, o tipo Pera, por apresentar os grãos prolatos, tectados, com uma columela curta. Sendo assim, analisou Pera glabrata e P. bicolor, descreveu os grãos de pólen com as seguintes características: 3-colporados; prolato-esferoidais; colpos estreitos, pequenos, costados, mas distintos; tectados, psilados e columela bastante reduzida. O mesmo autor comenta que este tipo polínico assemelha-se ao tipo Ricinus, por apresentar colpo estreito e uma columela pouco perceptível, diferenciando-se pelos colpos costados, ou seja, com um espessamento da nexina/endexina nos bordos da endoabertura, presente no tipo Pera. Considerou Pera e Ricinus como pertencentes à configuração Mallotus, embora neste último os grãos sejam oblato-esferoidais a suboblatos, algumas vezes esferoidais. Mais recentemente, Nowicke et al. (1998) estudaram os grãos de pólen da subfamília Acalyphoideae, analisando 12 espécies de Pera, evidenciando três tipos polínicos, a saber:

- tipo Pera arborea: pólen oblato-esferoidal em visão equatorial; 3-colporado; teto irregular; columela intectada, camada interior fina e consistente. Este tipo apresenta-se apenas em Pera arborea. A columela intectada caracteriza esse tipo de pólen, sendo rara em Euphorbiaceae e por isso deve ser tratado como um tipo à parte.

- tipo Pera parvifolia: pólen prolato-esferoidal a subprolato em visão equatorial; 3-(raramente 4)-colporado; teto pontuado, microruguloso ou finamente reticulado, ectexina fina; columela pequena; camada interior fina a grossa, consistente. Tipo presente em 10 espécies: $P$. barbellata, $P$. bicolor, $P$. bumelifolia, P. decipiens, P. domingensis, P. glabrata, P. obovata, P. parvifolia, P. polylepis e P. tomentosa. A principal característica é a columela pequena. Pera tomentosa é a espécie que mais se diferencia quanto ao tipo de pólen, por apresentar exina extremamente fina e o tecto reticulado; foi considerada no tipo $P$. parvifolia, por estar mais próxima da delimitação desse grupo, mas isso não significa que mantenha uma relação direta com o mesmo.

- tipo Pera distichophylla: pólen subprolato em visão equatorial; 3-(raramente 4)-colporado; teto pontuado, ectexina mediana; columela longa; camada interior fina, consistente. Presente apenas em Pera distichophylla. O tipo P. distichophylla se separa dos demais pela camada longa da columela, em contraste com o tipo $P$. parvifolia, cuja camada é pequena, e o tipo $P$. arborea, no qual é inexistente. Além disso, é o grão pólen que apresenta maior tamanho, diferenciando-se dos demais (Nowicke et al. 1998).

Nowicke et al. (1998) não confirmaram se o pólen de Pera pertence à configuração Mallotus, conforme sugeriu Punt (1962), já que o tipo Pera arborea apresenta pólen intectado, e o tipo $P$. distichophylla apresenta uma columela larga, separando-os daquele tipo de configuração. A indicação de $P$. distichophylla isoladamente em um tipo polínico confirma a separação dessa espécie em uma secção isolada. Nowicke et al. (1998) acreditam que apesar da diferença nos grãos de pólen, Pera deve ser considerado como um táxon monofilético.

\section{Fruto}

Os frutos das espécies de Pera (Fig. 1p-q), tanto em estado in natura como desidratados, são muito semelhantes entre si, variando apenas em relação ao tipo de indumento e algumas vezes quanto à forma. As espécies de Pera apresentam fruto do tipo cápsula septífraga. Quando in natura é possível observar que a deiscência desses frutos se dá através da coluna central, que se desfaz em três segmentos, cada qual com uma semente (Barroso et al. 1999). O carpóforo é persistente. De acordo com Barroso et al. (1999), além de Pera, Richeria e Chaetocarpus, algumas espécies de Sapium e de Croton também apresentam esse tipo de fruto.

\section{Sementes}

As sementes também não apresentam diferenças significativas para a separação das espécies (Fig. 1s). São sempre de cor preta e apresentam uma carúncula avermelhada, que as envolvem em 1/3 
a 2/3. Francisco et al. (2007) informaram que a coloração da carúncula, em contraste com a cor da semente, serve para despertar a atenção das aves e a alta produção de frutos facilita-lhes a alimentação, bem como a dispersão das sementes. Tokuoka \& Tobe (2003) descreveram as sementes de Pera como testais, apresentando tegumento externo traqueal. Essa característica difere das demais espécies da subfamília Acalyphoideae, pois a maioria apresenta semente com tegumento externo em paliçada, e sementes tégmicas.

\section{Usos}

Duas espécies têm uso popular: Pera glabrata, que é reputada na sapataria para a fabricação de tamancos e solados de sapatos em geral (Lorenzi 1992), e Pera benensis, que é utilizada na medicina tradicional dos índios Chimane, da Bolívia, no tratamento da leishmaniose cutânea (Fournet et al. 1992).

\section{Tratamento Taxonômico}

Pera Mutis, Kongl. Svenska Vetensk. Acad. Handl., 5:299, t.8. 1784.

Espécie-tipo. Pera arborea Mutis (Colômbia). Tipo: Estampa VIII, de Joseph Celestino Mutis (Kongl. Svenska Vetensk. Acad. Handl., 5:299, t.8. 1784). Pax \& Hoffmann (1919) citam a coleção Mutis 3561, coletada em Mariquito, Colômbia, como o tipo; entretanto, consultando-se a obra original não se encontrou nenhuma referência a tal coleção, apenas a estampa da espécie.

Perula Schreb., Gen. Pl., 2: 703. 1791. nom. nud.

Spixia Leandro, Denkscriften der Königlichen Academie der Wissenschaften zu München 7:231. 1821. Tipo: Estampa 13 (Tab. XIII) de P. Leandro de Sacramento.

Peridium Schott, in Spreng., Syst. 4(2) (Cur. Post.): 410. 1827. Tipo não designado.

Schismatopera Klotzsch, in Archiv für Naturgeschichte 7: 178. 1841. Tipo: Estampa A (Tafel VII, S. martiana K1.) de Klotzsch.

Arbusto, arvoreta ou árvore, dióicos, raramente monóicos. Ramos com indumento seríceo, tomentoso, raramente glabros, tricomas simples ou variando de estrelados a lepidotos. Folhas alternas ou excepcionalmente opostas, peninérveas, crassas a membranáceas, elípticas a oblongas, margem inteira, base cuneada a obtusa, ápice arredondado a acuminado; face adaxial glabra ou pilosa, tricomas simples ou variando de estrelados a lepidotos, especialmente concentrados na nervura principal; face abaxial glabra ou pilosa, tricomas simples ou variando de estrelados a lepidotos; pecíolo canaliculado ou inteiro, em geral piloso, tricomas simples ou variando de estrelados a lepidotos; estípulas ausentes; glândulas plateliformes presentes ou ausentes. Inflorescências unissexuadas ou, raramente, bissexuadas, em pseudantos axilares, fasciculados, pseudantial (Gillespie \& Armbruster 1997), ou inseridos em uma espiga, sempre indumentadas, tricomas simples ou variando de estrelados a lepidotos, pedunculadas; bractéolas 2 ou, raramente 1 , na base do invólucro; invólucro globoso a subgloboso, crasso, seríceo a tomentoso externamente, tricomas simples ou variando de estrelados a lepidotos, glabro internamente, na antese abrindo-se por uma fenda longitudinal ou com invólucro totalmente aberto. Flores estaminadas 3, sésseis ou, raramente, pediceladas, monoclamídeas, cálice 3-4-5 lobado, turbinado, urceloado, lobado, laciniado ou disforme; estames 3-4-5-6 por flor, filetes parcialmente ou completamente conados desde a base ou formando uma coluna estaminal; anteras rimosas, dorsofixas; pistilódios desenvolvidos, filiformes, sepalóides ou ausentes; grãos de pólen oblato-esferoidais, prolatoesferoidais a subprolatos, 3 (raramente 4-)-colpado. Flores pistiladas 4, sésseis ou pediceladas, aclamídeas; ovário piriforme, lageniforme ou globoso, piloso, raramente glabro, tricomas simples ou variando de estrelados a lepidotos; estigma trífido ou indiviso, face adaxial papilosa, face abaxial pilosa ou glabra, tricomas simples ou variando de estrelados a lepidotos, estaminódios presentes ou ausentes. Fruto cápsula septífraga, globoso, subgloboso ou clavado, mericarpos 3, pilosos ou raramente glabros, mesocarpo liso. Sementes elipsóides a globosas, carunculadas.

\section{Classificação infragenérica}

Pera sect. Neopera Griseb. Nachr. Gesellsch. Wiss. Göttingen 180. 1865. Tipo: Cuba, Wright 1988 (holótipo MO; foto do tipo MO).

Plantas dióicas, com indumento de tricomas simples, estrelados a lepidotos; invólucro da inflorescência abrindo-se por uma fenda longitudinal na antese; duas bractéolas na base do invólucro; flores estaminadas monoclamídeas, com os estames soldados na base, anteras apicifixas, e pistilódio ausente ou raramente com um pistilódio filiforme externo; flores pistiladas com estigma trífido e três estaminódios sepalóides. O pólen é do tipo $P$. parvifolia (Nowicke et al. 1998). Na Amazônia ocorrem seis espécies desta seção: Pera bicolor, $P$. coccinea, . decipiens, $P$. tomentosa, P. pulchrifolia e Pera manausensis. 
Pera sect. Pera Bigio \& Secco, nom. nov. Tipo: Brasil, Rio de Janeiro 1819, Leandro 2 (holótipo M).

Pera sect. Spixia Schrank, Denksch. Köningl. Acad. Wissensch. München 7: 242. 1821, syn. nov. Pera sect. Perula (Schreb.) Pax \& K. Hoffm., Das Pflanz. IV. 147. XIII: 3, syn. nov.

Plantas dióicas, com indumento de tricomas simples, estrelados a lepidotos; bráctea involucral totalmente aberta na antese; duas bractéolas na base do invólucro; flores estaminadas monoclamídeas, circundadas por quatro pistilódios desenvolvidos; estames soldados da base até a metade do filete e anteras dorsifixas; flores pistiladas com estigma indiviso, podendo ser cinrcundadas por estaminódios sepalóides. Provavelmente o pólen seja semelhante ao tipo Pera arborea (Nowicke et al 1998). Na Amazônia ocorrem quatro espécies desta seção: Pera anisotricha, $P$. heteranthera, $P$. membranacea e Pera eiteniorum Bigio \& Secco.

Devido acreditar-se que Pera arborea, a espécietipo do gênero, pertença à antiga Pera sect. Spixia, que abriga espécies cuja bráctea involucral se abre completamente na antese, foi necessário propôr um nome novo para referida seção, uma vez que Pax \& Hoffmann (1919) não estabeleceram Pera sect. Pera.

Pera sect. Peridium (Schott) Müll. Arg., DC. Prodr. XV (2): 1029. 1866. Tipo não designado.

Plantas dióicas, com indumento de tricomas lepidotos; invólucro da inflorescência abrindose por uma fenda longitudinal na antese; duas bractéolas na base do invólucro; flores estaminadas aclamídeas, com estames soldados na base, anteras apicifixas; pistilódio presente ou ausente; flores pistiladas com estigma trífido, com um estaminódio sepalóide externo. O pólen é do tipo P. parvifolia (Nowicke et al. 1998). Na Amazônia ocorrem duas espécies desta seção: Pera glabrata e $P$. benensis.

Pera sect. Peridium separa-se da Pera sect. Neopera unicamente pelo fato de as flores estaminadas não apresentarem cálice ou, se presente, extremamente reduzido; mas os autores aqui acreditam que esta seja uma relevante característica morfológica para diferenciá-las.

Pera sect. Schismatopera (Klotzsch) Baill., Etud. Gen. Euphorb. 434. 1858. Tipo: Estampa A (Tafel VII, S. martiana K1.)

Pera sect. Diplopera Müll. Arg., Fl. Bras. XI (2): 423. 1874., syn. nov.

Plantas monóicas, com indumento de tricomas simples; invólucro da inflorescência totalmente aberto na antese; uma única bractéola na base do invólucro; flores estaminadas monoclamídeas, apresentando coluna estaminal, anteras dorsifixas e ausência de pistilódio; flores pistiladas com estigma indiviso e ausência de estaminódio. O pólen é do tipo P. distichophylla (Nowicke et al, 1998). Consta de uma espécie: Pera distichophylla.

Pera sect. Diplopera era representada por Pera heterodoxa, esta espécie foi considerada sinônimo de P. distichophylla por Jablonski (1967). Devido a isso, esta seção é aqui considerada sinônimo de $P$. sect. Schismatopera.

\section{Chave para a identificação das espécies de Pera ocorrentes na Amazônia brasileira}

1. Folhas alternas.

2. Face abaxial da folha esparso-serícea, tricomas simples; inflorescências bissexuadas, com apenas uma bractéola na base do invólucro 13. P. distichophylla

2'. Face abaxial da folha pubescente, tomentosa, denso-lepidota, com tricomas lepidotos, lepidotoradiados, lepidoto-estrelados, estrelado-lepidotos ou estrelados; inflorescências unissexuadas, com duas bractéolas opostas na base do invólucro

3. Invólucro da inflorescência abrindo-se totalmente na antese; flores estaminadas com pistilódio desenvolvido (rudimento de flor pistilada); flores pistiladas com estigma indiviso.

4. Folhas membranáceas, com glândulas pateliformes na face abaxial; flores pistiladas com ovário piriforme 10. P. membranacea

4'. Folhas subcoriáceas a crassas, sem glândulas na face abaxial; flores pistiladas com ovário lageniforme.

5. Folhas sem indumento barbado nas axilas das nervuras, na face abaxial; flores estaminadas pediceladas; flores pistiladas com ovário tomentoso, tricomas estrelados.

6. Face abaxial das folhas com tricomas estrelados-porrectos; cálice da flor estaminada ciliado, tricomas simples; flor pistilada com estigma umbraculiforme, estaminódio filiforme ausente. 9. P. heteranthera 
6'. Face abaxial das folhas com tricomas estrelados a estrelado-lepidotos; cálice da flor estaminada esparso-seríceo, tricomas simples ou raramente glabro; flor pistilada com estigma triangular, estaminódio filiforme presente

8. P. eiteniorum

5'. Folhas com indumento barbado nas axilas das nervuras secundárias, na face abaxial; flores estaminadas sésseis; flores pistiladas com ovário pubescente, tricomas estrelado-lepidotos .... 7. P. anisotricha

3'. Invólucro da inflorescência abrindo-se por uma fenda longitudinal na antese; flores estaminadas sem pistilódio desenvolvido (rudimento de flor pistilada); flores pistiladas com estigma trífido.

7. Folhas com tricomas lepidotos e/ou lepidoto-radiados; glândulas pateliformes presentes na face abaxial das folhas.

8. Flores estaminadas com cálice reduzido, disforme; flores pistiladas com 1 estaminódio sepalóide externo 12. P. glabrata

8'. Flores estaminadas com cálice 3-lobado; flores pistiladas com 3-4 estaminódios sepalóides e 1 estaminódio filiforme externo. 2. P. coccinea

7'. Folhas com tricomas lepidotos-estrelados, estrelados e estrelado-lepidotos; glândulas ausentes

9. Face abaxial das folhas esparso pubescente, tricomas estrelados, não emaranhados; flores estaminadas com cálice irregular, laciniado 1. P. bicolor

9'. Face abaxial das folhas denso lepidota ou tomentosa, tricomas lepidoto-estrelados e estrelados, emaranhados; flores estaminadas com cálice campanulado, 3-lobado.

10. Flores pistiladas com estigma de lobos bipartidos; 1-2 estaminódios centrais ...... 4. P. manausensis

10'. Flores pistiladas com estigma de lobos inteiros; 3 estaminódios centrais.

11. Folhas com tricomas lepidoto-estrelados emaranhados na face abaxial; flores pistiladas subsésseis; ovário piriforme denso-lepidoto, tricomas lepidotos ...

3. P. decipiens

11'. Folhas com tricomas estrelados emaranhados na face abaxial; flores pistiladas sésseis; ovário globoso denso-tomentoso, tricomas estrelados

5. P. tomentosa

1'. Folhas opostas.

12. Face abaxial da folha denso-lepidota, tricomas lepidoto-radiados; invólucro da inflorescência denso-lepidoto, tricomas lepidoto-radiados; flores estaminadas com cálice reduzido disforme, estrigoso, tricomas simples 11. P. benensis

12'. Face abaxial da folha denso-tomentosa, tricomas estrelados; invólucro da inflorescência tomentoso, tricomas estrelados; flores estaminadas com cálice campanulado, tomentoso, tricomas estrelados 6. P. pulchrifolia

\section{Pera sect. Neopera Griseb.}

1. Pera bicolor (Klotzch) Müll. Arg., DC., Prodr. 15(2): 1028, 1866. Peridum bicolor Klotzsch, Hooker's J. Bot. Kew Gard. Misc., 2: 44, 1843. Tipo: GUYANA. Schomburgk 114 (lectótipo G-DC, designado por Gillespie (1993); isolectótipos G, K, P, U, W; fotos IAN!, G!, L!, K!). Tig. 2

Peridium schomburgkii Klotzsch, M.R. Schomburgk, Fauna Fl. Brit. Gui.: 1089, nom. nud. Peridium schomburgkianum Klotzsch, Fauna Fl. Brit. Gui.: 1089 (1848[1849]), nom. nud.

Pera citriodora Baill., Adansonia 5: 222. 1865. Tipo: VENEZUELA. Amazonas, near San Carlos, rio Negro, 1853-54, Spruce 3686 (holótipo $\mathrm{P}$; isótipos BR, G, G-DC, GH, K, MO, NY, P, RB!; fotos BR!, G!, G-DC!, K! MO!, NY!, P!), syn. nov.
Pera schomburgkiana Müll. Arg. in DC., Prodr. 15(2): 1027. 1866. Tipo: GUIANA/ VENEZUELA. Roraima, 1843, fl., Rich Schomburgk 901, 905 (síntipos K; foto K!); GUIANA/VENEZUELA. Roraima, 1843, fl., Rob Schomburgk II 580 (síntipo K; G; P; U; foto L!, G!, K!, M!).

Arvoretas ou árvores dióicas, 5-20 m alt. $\times$ 15-23 cm diâm. Ramos glabros. Folhas alternas, peninérveas, nervuras pouco proeminentes na face abaxial, $8-17 \mathrm{~cm}$ compr. $\times 3-6 \mathrm{~cm}$ larg., elíptico-lanceoladas, coriáceas, subcoriáceas a membranáceas, margem inteira, base cuneada, ápice agudo a levemente acuminado; face adaxial esparso pubescente, tricomas estrelados, mais concentrados na nervura principal; face 


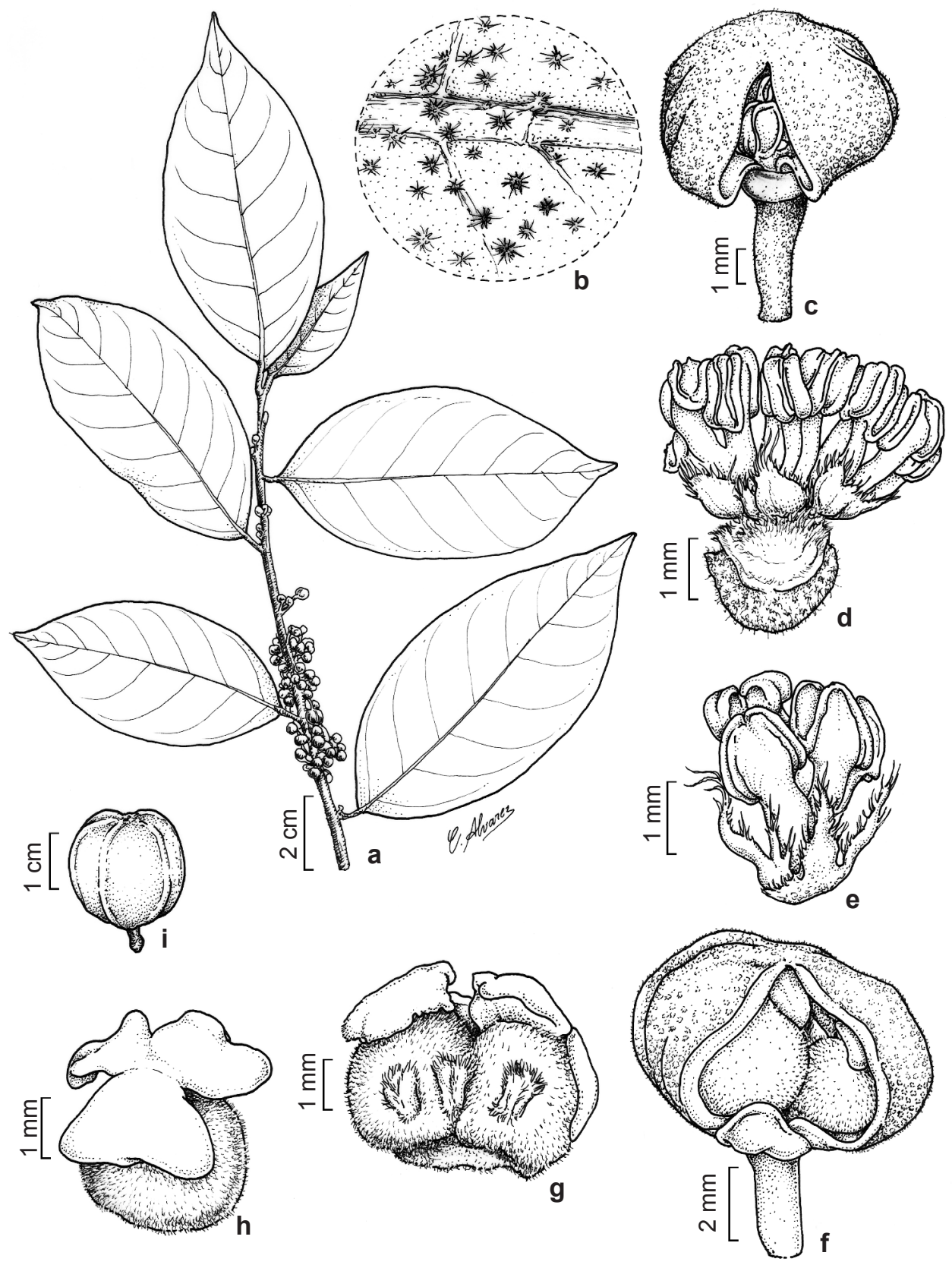

Figura 2-Pera bicolor (Klotzsch) Müll. Arg. - a. ramo, inflorescências estaminadas; b. detalhe da superfície abaxial da folha, tricomas estrelados; c. inflorescência estaminada, invólucro abrindo-se através de fenda longitudinal na antese; $d$. inflorescência estaminada, invólucro retirado; e. flor estaminada, cálice laciniado, rudimentar; f. inflorescência pistilada, invólucro abrindo-se através de fenda longitudinal na antese; g. duas flores pistiladas, três estaminódios sepalóides; h. flor pistilada, estigma trífido, bipartido, ovário; i. fruto imaturo. (a-b A. Ducke s/n (RB 2088); c W. Rodrigues et al. 4707; d-e Francisco s/n (MG 21526); f-h Dionísio s/n (MG 21518); i: J.A. Silva 269).

Figure 2 - Pera bicolor (Klotzsch) Müll. Arg. - a. branch, staminate inflorescences; b. detail of the lower surface of the leaf, stellate trichomes; c. staminate inflorescence opening by a longitudinal slit at anthesis; d. staminate inflorescence, involucre removed; e. staminate flowers, rudimentary laciniate calyx; f. pistillate inflorescence opening by a longitudinal slit at anthesis; g. two pistillate flowers, three sepaloid staminodia; h. pistillate flower, 3-lobed stigma, twice divided, tomentose ovary. (a-b A. Ducke s/n (RB 2088); c W. Rodrigues et al. 4707; d-e Francisco s/n (MG 21526); f-h Dionísio s/n (MG 21518); i J.A. Silva 269). 
abaxial esparso pubescente, tricomas estrelados e estrelado-lepidotos, não emaranhados, glândulas ausentes; pecíolo 0,6-1,0 cm compr., canaliculado, pubescente, tricomas estrelados a estreladolepidotos. Inflorescências pseudantos axilares, fasciculados, unissexuadas, pubescentes, tricomas estrelados e estrelados-lepidotos, pedúnculo 5-8 mm compr., pubescente, estrelado-lepidoto; bractéolas 2, 0,9-1 mm diâm. na base do invólucro, orbiculares, opostas, pubescentes, tricomas estrelados; invólucro globoso, coriáceo, pubescente, tricomas estrelados a estrelados-lepidotos, o das flores estaminadas 3-4 mm diâm., o das flores pistiladas 5-7 mm diâm., ambos abrindose por uma fenda logitudinal na antese. Flores estaminadas sésseis, cálice irregular, laciniado, 0,2-0,5 mm compr., ciliado, tricomas simples, ou pubescente, tricomas estrelados, raramente distribuídos no restante do cálice; estames 3-4 por flor, 0,8-1,3 mm compr., filetes concrescidos na base, glabros, anteras 0,7-1,0 mm compr., pistilódio ausente. Flores pistiladas subsésseis ca. 0,1 mm compr., ovário 1,5-2 mm diâm., piriforme, tomentoso, tricomas estrelados, estilete subséssil 0,2 mm, estigma trífido, lobos bipartidos, 1,5-2 mm compr., face abaxial pubescente, tricomas estrelados, adaxial glabra, papilosa, estaminódio filiforme 1, ca. 0,8 mm compr., no centro das flores pistiladas, seríceo, tricomas simples. Fruto ca. 1,8 cm diâm. x ca. 2 cm compr., subgloboso, rugoso, tomentoso, tricomas estrelados, pedúnculo ca. 0,3 mm compr. Sementes 6-8 mm compr. $\times 3-5$ $\mathrm{mm}$ larg., sub-ovóides, carúncula avermelhada, recobrindo $1 / 3$ da semente.

Material selecionado: AMAZONAS: Manicoré, BR230, rio Marmelos, 750'S, 6215'W, 15.IV.1985, fl., C.A. Cid Ferreira 5564 (INPA); Barcelos, rio Javari, $0^{\circ} 42$ 'N 632'' ' 4.VII.1985, fr., J.A. Silva 269 (INPA); Santa Isabel, rio Uneuxi, $0^{\circ} 32^{\prime} \mathrm{S} 62^{\circ} 04^{\prime} \mathrm{W}, 12.08 .2000$, fl. (ठ), D.A. Lima Filho et al. 46 (MG); rio Preto, Igarapé Matupiri, bacia do rio Negro, caatinga, 10.XI.1947, fl., R.L. Fróes 22801 (IAN); Itaubal, rio Araçá, rio Negro, 26.X.1952, fl. (ठđ), R.L. Fróes et al. 29098 (IAN, UB); Manaus, Parque 10, 12.VII.1955, fl. (ठ), Francisco $s / n$ (MG 21526); Ponte do Mindí, capoeira, 10.VII..1936, fl. () e fr., A. Ducke $s / n$ (RB 35489); Rio Negro,

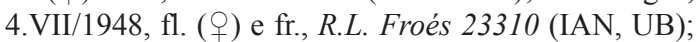
Bacia do rio Negro, rio Aracá, igarapé do Romão, 11.IX.1988, fl. (ठ̊), K. Kubitzki 88-110 (MG); Baixo rio Negro, campina do Tamacoera, 20.X.1912, A. Ducke 12196 (MG); rio Negro, São Joaquim, 8.VIII.1913, fl. (ふ), A. Ducke s/n (RB 2088); São Gabriel da Cachoeira, $1^{\circ} 21^{\prime} \mathrm{N} 66^{\circ} 50^{\prime}$ W, 27.X.1987, fl., C. Farney et al. 1800 (RB); Reserva Ducke, floresta de vertente, 5.XII.1995, fr., M.A.S. Costa 433 (RB, MG). MATO GROSSO: $20 \mathrm{~km}$ leste de Vilhena, 24.IX.1963, fl. (ठ), J.M. Pires (UB). RONDÔNIA: sítio da Mini-Usina, $40 \mathrm{~km}$ da Alta Floresta do Oeste, $12^{\circ} 14^{\prime}$ 'S 62 $2^{\circ}$ 'W, 12.VIII.1999, fl. (ठ̋), J.A. Ratter et al. 8262 (UB); Porto Velho, Vista Alegre do Abunã, 22.X.1997 (fl), L.C.B. Lobato 2040 (MG).

Distribuiçãogeográfica: Venezuela(Amazonas, Bolívar), Guianas (Gillespie \& Armbruster 1997), Brasil (Amazonas, Rondônia, Mato Grosso).

Klotzsch (1843) publicou Peridium bicolor, com base no espécime Schomburgk 114, dando mais ênfase à parte vegetativa, descrevendo as flores pistiladas com o ovário viloso e o estigma obtuso, trilobado.

Bentham (1854) descreveu duas variedades para Peridium bicolor: Peridium bicolor var. tomentosum, utilizando Schomburgk 114, coletado na Guiana, e Spruce $s / n$ das capoeiras próximas ao rio Negro, como tipos; e $P$. bicolor var. nitidum, com base nas coleções de Rob. Schomburgk 685, 686 e Rich. Schomburgk 1070, 1071. Referido autor diferenciou uma da outra pelos tricomas na face abaxial: tomentosa na primeira variedade, e tricomas lepidotos e tricomas pontuais na segunda. Bentham (1854) deveria ter mantido um autônimo (Peridium bicolor var. bicolor) com o tipo Schomburgk 114, o que não fez.

Müller (1865) descreveu Pera decipiens, baseado nas amostras de Rich. Schomburgk 1070, 1071, não considerando Peridium bicolor var. nitidum como sinônimo, e por isso não citou os demais espécimes utilizados por Bentham (1854). A referida espécie apresentava a face abaxial com tricomas densamente lepidoto-tomentoso, invólucros tomentosos e o ovário com tricomas lepidotos peltiformes.

Müller (1866) fez uma nova combinação com base em Peridium bicolor Klotzsch, estabelecendo Pera bicolor, e citando as amostras Schomburgk 114, 685, 686, colocando Peridium bicolor var. nitidum como sinônimo. Ao descrever a nova combinação, assim a caracterizou: folhas com a face abaxial contendo tricomas lepidotos de raios grandes e o ovário com densa camada de tricomas rufo-vilosos.

Müller (1866) também propôs um status novum para Peridium bicolor var. tomentosum Benth., estabelecendo Pera tomentosa (Benth.) Müll. Arg., citando os espécimes Poeppig 2640 e $R$. Spruce 1820, 3219, 3374, assim caracterizando tal espécie: folhas com a face abaxial contendo denso indumento opaco de tricomas lepidototomentosos, longamente radiados e ovário com tricomas fasciculados, denso-tomentosos. 
Pax \& Hoffmann (1919) seguiram o conceito de Müller (1866) para Pera tomentosa, porém não concordam com a espécie Pera decipiens e a sinonimizam como Pera bicolor, mantendo a separação feita por Bentham (1854) para Peridium bicolor var. nitidum. Referidos autores assim caracterizaram as espécies aceitas: Pera tomentosa apresentando folhas com a face abaxial contendo um emaranhado denso de tricomas estreladotomentosos e ovário tomentoso; e Pera bicolor tendo folhas com face abaxial contendo um denso indumento de tricomas estrelado-lepidotos, não emaranhados e ovário com tricomas rufo-vilosos.

Lanjouw (1931) percebeu a existência do problema da delimitação de Pera bicolor, $P$. decipiens e $P$. tomentosa, designando então os espécimes Schomburgk 114 como Pera bicolor; Rob Schomburgk 685, 686 e Rich. Schomburgk 1070, 1071 como Pera decipiens, não fazendo nenhuma alteração nos tipos de $P$. tomentosa. O mesmo autor foi o primeiro a considerar $P$. schomburgkiana (Benth.) Müll. Arg. como sinônimo de Pera bicolor, já que o espécime coletado no Suriname apresentou rudimento de flores pistiladas na inflorescência estaminada.

Lanjouw (1939) sinonimizou Peridium bicolor var. tomentosum (ex parte) como Pera bicolor e não citou Pera schomburgkiana como sinônimo desta, e nem tampouco fez referência aos tipos, novamente causando confusão na delimitação dos táxons.

Jablonski (1967) propôs um status novum para Peridium bicolor var. nitidum, nominando-a como Pera nitida (Benth.) Jablonski, tendo como sinônimo Pera decipiens e como tipos as coleções Rob. Schomburgk 685, 686; Rich Schomburgk 1070, 1071 e Spruce s/n. No caso de Pera bicolor, o mesmo autor colocou como sinônimos Peridium bicolor, Peridium bicolor var. tomentosoum, Pera cinerea Baill. e Pera tomentosa, sendo Schomburgk 114 o tipo desta última.

Silva Alves (1993) considerou três espécies: Pera nitida, P. cinerea Baill. e P. bicolor, e apontou alguns novos lectótipos. Para $P$. nitida designou P. bicolor var. nitidum como sinônimo e como lectótipo Schomburgk 1071; no caso de P. decipiens, apontou Schomburgk 1071 como lectótipo; sob $P$. cinerea citou os nomen nudum Spixia cinerea Poepp e Peridium cenereum Poepp. como sinônimos, e Poeppig 2640 como lectótipo. Nesse conceito de Silva Alves (1993), Pera cinerea seria o que considera-se hoje Pera tomentosa. Para P. bicolor, o mesmo autor citou como basiônimo Peridium bicolor, sendo o tipo a coleção Schomburgk 114; e P. bicolor var. tomentosum como sinônimo de Pera bicolor, considerando o mesmo tipo. Silva Alves (1993) não citou a coleção Spruce $s / n$, que também foi utilizada para descrever Peridium bicolor var. tomentosum Benth, mantendo assim a dificuldade de separação desses táxons.

Gillespie (1993) considerou Pera bicolor, P. decipiens e $P$. tomentosa como espécies válidas. Para Pera bicolor, a autora citou como sinônimos Peridium bicolor (tipo: Schomburgk 114) e Pera schomburgkiana (tipos: Ri. Schomburgk 901, 905 e Ro. Schomburgk 580); para P. decipiens considerou como sinônimos Peridium bicolor var. nitidum e Pera nitida, designando como lectótipos Ri. Schomburgk 1070 e 1071; e em P. tomentosa citou como sinônimos Peridium bicolor var. tomentosum e Pera tomentosa, tendo como lectótipo Spruce 1820. Esse conceito proposto por Gillespie (1993) é o mais coerente, já que conseguiu solucionar o problema das delimitações dos tipos (Schomburgk 114 e Spruce $s / n$ ), agrupados, como um lapso, por Bentham (1854) em Peridium bicolor var. tomentosum.

Por apresentar tricomas estrelados na face abaxial e ovário tomentoso, $P$. bicolor parece estar mais próxima de $P$. tomentosa, porém desta se distingue pela distribuição esparsa de tricomas na face abaxial das folhas, pelo cálice irregular das flores pistiladas, ovário piriforme, indumento de coloração avermelhada no material seco, estigma trífido, bipartido e um estaminódio no centro das flores pistiladas. As características que separam $P$. bicolor das demais espécies de Pera sect. Neopera ocorrentes na Amazônia brasileira podem ser vista na chave aqui fornecida.

A distribuição de P. bicolor contemplava apenas a parte norte da Amazônia. Entretanto, neste trabalho encontraram-se coletas dessa espécie em Rondônia e Mato Grosso, ampliando assim a sua distribuição.

2. Pera coccinea (Benth.) Müll. Arg., in DC., Prodr. 15(2): 1028. 1866. Peridium coccineum Benth., Hooker's J. Bot. Kew Gard. Misc. 6: 323. 1854. Tipo: BRASIL. PARÁ. on shores of the Lago de Obidos, XII.1949, fl., Spruce 488 (holótipo K; isótipos E, P; fotos F!, IAN!, K!). $\quad$ Fig. 3

Pera incisa Leal, Arq. Jard. Bot. Rio de Janeiro 11: 65. 1951. Tipo: BRASIL. PARÁ. Aveiro, Rio Tapajós, 21.IV.1924, fr., J.G. Kuhlmann 1890 (holótipo, RB 20725!). syn. nov.

Arbustos a árvores dióicos, 3-15 m alt. Ramos esparso-lepidotos, tricomas lepidoto-radiados. 
Folhas alternas, peninérveas, nervuras pouco proeminentes na face abaxial, $7-15,5 \mathrm{~cm}$ compr. $\times 3-6 \mathrm{~cm}$ larg., elípticas a elíptico-lanceoladas, coriáceas, margem inteira, base cuneada, ápice agudo a acuminado; face adaxial glabra; face abaxial esparso-lepidota, tricomas lepidoto-radiados; glândulas pateliformes ao lado da nervura principal, em geral nas axilas das nervuras secundárias da face abaxial; pecíolo $0,5-2 \mathrm{~cm}$ compr., canaliculado, com tricomas lepidoto-radiados. Inflorescências pseudantos axilares, fasciculados, unissexuadas, com tricomas lepidoto-radiados; pedúnculo 3-4 $\mathrm{mm}$ compr., lepidoto, tricomas lepidoto-radiados; bractéolas 2, 1-2 mm diâm. na base do invólucro, orbiculares, opostas, lepidotas, tricomas lepidotoradiados; invólucro subgloboso a globoso, coriáceo, denso a esparso-lepidoto, tricomas lepidotos, o das flores estaminadas $3-5 \mathrm{~mm}$ diâm., o das flores pistiladas $0,5-1 \mathrm{~mm}$ diâm, ambos abrindose por uma fenda longitudinal na antese. Flores estaminadas sésseis, cálice campanulado, 3-lobado, lobos $0,8-1,2 \mathrm{~mm}$ compr., concrescidos na base, ápice lacerado, ciliados, tricoma simples, glabro internamente; estames 3-4 por flor, 2-3 mm compr., filetes concrescidos na base, glabros, anteras $0,3-0,6$ $\mathrm{mm}$ compr., pistilódio desenvolvido (rudimento de flor pistilada) ausente, pistilódio filiforme $1,1 \mathrm{~mm}$ compr., lepidoto, tricomas lepidoto-radiados. Flores pistiladas subsésseis, pedicelo ca. $0,3 \mathrm{~mm}$ compr., ovário 1,5-2 mm diâm., globoso, denso-lepidoto, tricomas lepidoto-radiados, estilete séssil, estigma trífido, lobos inteiros, $0,8-1 \mathrm{~mm}$ compr., face abaxial denso-lepidota, tricomas lepidotos, adaxial glabra, papilosa, estaminódios sepalóides 3-4, 1-1,5 mm compr. $\times 0,3-0,6 \mathrm{~mm}$ larg., obovado-oblongos, ciliado, tricoma simples, estaminódio filiforme, 1 , externo, ca. $1 \mathrm{~mm}$ compr., denso-lepidoto, tricomas lepidoto-radiados. Fruto $1-1,5 \mathrm{~cm}$ compr. $\times 1,5 \mathrm{~cm}$ diâm., globoso a subgloboso, rugoso, pubescente, tricomas lepidoto-radiados, pedúnculo $5-7 \mathrm{~mm}$ compr. Sementes $4-7 \mathrm{~mm}$ compr. $\times 4-5 \mathrm{~mm}$ larg., obcônicas, base obtusa, ápice arredondado, carúncula avermelhada, cobrindo $1 / 2$ da semente. Material selecionado: AMAZONAS: rio Solimões, Auati parana, lago Buiussu, 12.X.1948 fl., M. Silva 2043 (MG); rio Purus, Lago Preto, north of Labrea, 25.VII.1971, fl., G.T. Prance 13673 (MG); rio Iça, igarapé Pauleta, 23.II.1977, fr. G.T. Prance 24533 (INPA). PARÁ: Parque Nacional do Tapajós. Ilha do Pacú, 30.XI.1978, fl.(P), M.G. Silva et al. 4034 (MG, UB); Alto Papajós, rio Cururú, Missão Cururú, $7^{\circ} 35^{\prime}$ 'S 57³1'W, 17.II.1974, fr., W.R. Anderson 11042 (RB); Óbidos, 22.XII.1903, fl. (đ)), A. Duckes/n (RB 195361);
Itaituba, estrada Itaituba-Jacareacanga, Parque Nacional

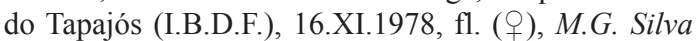
3767 (MG); Altamira, ilha Belo Horizonte, 11.X.1910, fl., A.T.G. Dias 494a (MG). RONDÔNIA: Alta Floresta, rio Mequens, 06.VII.1997, fl., L.C.B. Lobato et al. 1682 (MG); Alto Tapajós, rio Cururu, ca. $8^{\circ} \mathrm{S} 57^{\circ} 5^{\prime} \mathrm{W}$, 10.II.1974, fr. W.R. Anderson 10852 (INPA). MATO GROSSO: Expedition Base Camp, 1249'S 5146'W, rio Suiia Missú, 22.XI.1968, fl. (đ̋), R.M. Harley 11180 (UB, RB); rio Aripuanã, $10^{\circ} 12^{\prime}$ 'S 59 $21^{\prime}$ 'W, 19.X.1973, fl. (), C.C. Berg et al. P18670 (MG, UFMT); Vila Bela, rio Guaporé, 25.X.1983, fl. (ठ̋), Saddi et al. 3617 (RB); $\mathrm{St}^{\mathrm{a}}$ Terezinha, rio Araguaia, $10^{\circ} 25^{\prime} \mathrm{S} 50^{\circ} 30^{\prime} \mathrm{W}, 10 . \mathrm{X} .1985$, fl. ()), J.R.. Pirani 1202 (MG); São Felix do Araguaia, rio Araguaia, Lago dos Ingleses, $11^{\circ} 35^{\prime} \mathrm{S} 50^{\circ} 45^{\prime} \mathrm{W}$, 7.X.1985, fl., C.A. Cid Ferreira et al. 6370 (MG).

Distribuição geográfica: Brasil, estado do Amazonas, Pará, Tocantins (Silva Alves 1993), Mato Grosso e Goiás.

As folhas de Pera coccinea lembram as de P. glabrata, mas podem ser diferenciadas pois no material seco a coloração da folha de $P$. coccinea é mais opaca que a de $P$. glabrata, sendo que esta apresenta as folhas avermelhadas na face abaxial e escuras na adaxial. Pera coccinea tem tricomas lepidoto-radiados, enquanto $P$. glabrata apresenta tricomas lepidotos. Pera coccinea apresenta, no centro das flores pistiladas, 3-4 estaminódios sepalóides, e um estaminódio filiforme externo e as flores estaminadas com cálice 3-lobado, ao passo que em P. glabrata apresenta um estaminódio sepaloide externo e as flores estaminadas são aclamídeas ou com o cálice reduzido, disforme.

Bentham (1854), ao descrever Peridium coccineum, basiônimo de Pera coccinea, também informou que, à primeira vista, aquela se assemelhava a Peridium glabratum (=Pera glabrata) e os caracteres que as diferenciavam seriam os filetes das flores estaminadas, o número de flores pistiladas e a forma e textura dos invólucros. Neste estudo, não foram constadas essas diferenças, já que as flores pistiladas são sempre em número de 4 para as duas espécies. Bentham (1854) informou a existência de 8 flores pistiladas em $P$. coccineum e não relatou a presença dos estaminódios sepalóides, sendo que talvez o autor tenha confundido os estaminódios com flores, pois Pax \& Hoffmann (1919), analisando o material-tipo de Spruce, descreveram 4 flores pistiladas e 3 estaminódios centrais.

Bentham (1854) informou que nas plantas vivas de Peridium coccineum os invólucros apresentavam cores avermelhadas, com um pouco de amarelo na base, afirmando também que 


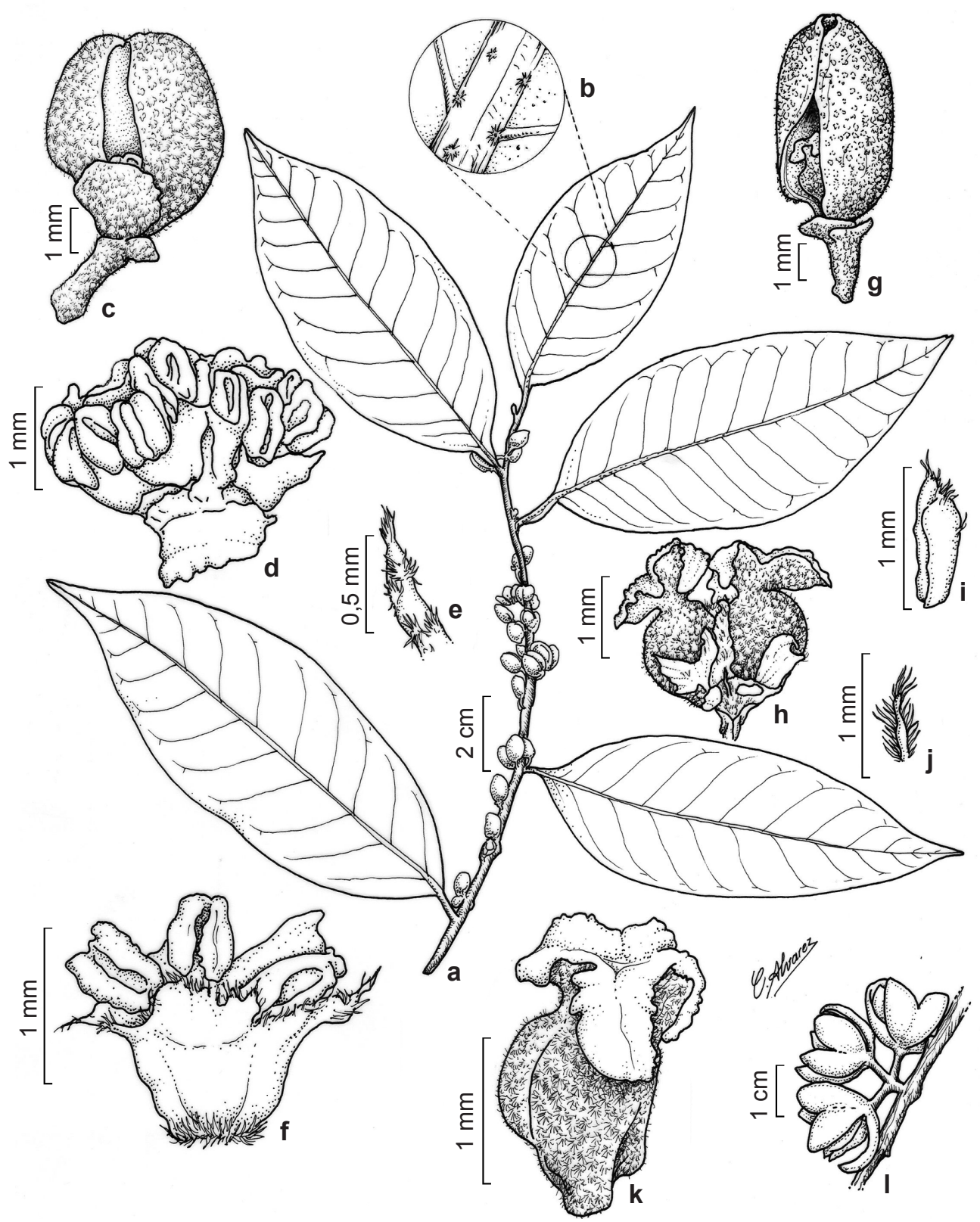

Figura 3 - Pera coccinea (Benth.) Müll. Arg. - a. ramo com inflorescências pistiladas; b. detalhe dos tricomas lepidotos esparsamente distribuídos especialmente na nervura principal, na face abaxial da folha; c. inflorescência estaminada abrindo-se por uma fenda longitudinal na antese; $d$. três flores estaminadas com invólucro removido e com um pistilódio externo; e. pistilódio filiforme; f. flor estaminada com cálice ciliado, tricomas simples; g. inflorescência pistilada abrindo-se por uma fenda longitudinal na antese; h. duas das quatro flores pistiladas mostrando os três estaminódios sepalóides centrais e um estaminódio filiforme externo; i. estaminódio sepalóide; j. estaminódio filiforme externo; k. flor pistilada com estigma 3-lobado; 1. frutos (a-b, g-h, k M.G. Silva et al. 4034; c, e-f R.M. Harley et al. 11180; d M.G. Silva 2043; i W.R. Anderson 11042).

Figure 3 - Pera coccinea (Benth.) Müll. Arg. - a. branch with pistillate inflorescences; b. detail of lower surface with trichomes lepidote sparsely distributed, concentrated in the midrib; c. staminate inflorescence opening by a longitudinal slit at anthesis; d. three staminate flowers with involucre removed and with an external pistilodium; e. filiform pistilodium; f. staminate flowers with ciliated calyx, simple trichomes; g. pistillate inflorescence opening by a longitudinal slit at anthesis; h. two pistilate flowers showing three central sepaloid staminodia and the external filiform staminodium; i. sepaloide staminodium; j. filiform staminodium; k. pistillate flower with 3-lobed stigma; 1. fruits. (a-b, g-h, k M.G. Silva et al. 4034; c, e-f R. M. Harley et al. 11180; d M.G. Silva 2043; i W.R. Anderson 11042). 
emitiam um cheiro adocicado. Provavelmente, a escolha do epíteto coccineum (igual a carmesim, avermelhado) se deva à cor vermelha do invólucro.

A coleção-tipo de Peridium coccineum parece um tanto confusa, pois Bentham (1854) utilizou-se da planta coletada por Spruce, no Lago de Óbidos, que foi designada pelo próprio Spruce como Peridium n. 2. Müller (1866) citou o material como sendo $R$. Spruce, coletado no estado do Pará, Óbidos. Este mesmo autor fez uma combinação, estabelecendo Pera coccinea e descrevendo-lhe os frutos, que até então eram desconhecidos. Pax \& Hoffman (1919) só citaram uma das plantas coletadas, Spruce 196, em Óbidos. Já no trabalho de Silva Alves (1993) foi designada a coleção Spruce 488 como tipo, e no material examinado o mesmo autor citou "Pará, Óbidos, Spruce 196 (M), Spruce 194 (M), Spruce 488, fem. (E, K, P), Spruce s.n., XII.1849”. É provável que todos esses espécimes sejam síntipos de $P$. coccinea, já que Bentham (1854) informou que sua descrição baseou-se no material coletado por Spruce, no lago de Óbidos. Nesta monografia, considerou-se a coleção (Spruce 488) citada por Müller (1866), como tipo de Peridium coccineum, até ter-se acesso às demais coleções aqui citadas.

Por apresentar invólucro unissexuado, bibracteolado, flores estaminadas destituídas de rudimentos de flores pistiladas, cálice da flor estaminada desenvolvido, filetes brevemente conados, invólucro da flor pistilada com estaminódios centrais e indumento lepidoto, Pera coccinea está posicionada em Pera sect. Neopera Griseb., juntamente com as seguintes espécies: P. bumelifolia Griseb.; P. domingensis Urb., que ocorre em Santo Domingos, P. bicolor, P. decipiens e P. tomentosa, que ocorrem na Amazônia (Müller 1866; Müller 1874; Pax \& Hoffmann 1919). As diferenças entre as espécies amazônicas podem ser visualizadas na chave aqui fornecida.

Pax \& Hoffmann (1919) comentaram que $P$. coccinea, $P$. bumelifolia e $P$. domingensis são espécies muito parecidas, mas não destacaram em quais características. E nas descrições, referidos autores não apresentam detalhes suficientemente fortes para separá-las ou agrupá-las, sendo que, na chave, os caracteres que as separam são o formato do invólucro, que pode ser globoso-elipsóide ou globoso e o ápice das folhas, que varia de acuminado a obtuso; entretanto, tais características não são seguras para diferenciar as espécies de Pera. Nas descrições de Grisebach (1865) e Urban (1912) poucas diferenças são encontradas em relação às descrições propostas por Pax \& Hoffmann (1919).
Pelas fotos dos tipos (F, NY), P. coccinea, $P$. bumelifolia e $P$. domingensis são parecidas, mas seria necessário uma análise mais detalhada dos tipos para tratá-las ou não como sinônimos. Govaerts et al. (2000), no checklist de Euphorbiaceae, apontaram P. domingensis como sinônimo de P. bumelifolia.

Pera incisa Leal foi aqui considerada como sinônimo de $P$. coccinea, porque a característica utilizada por Leal (1951) para propô-la como uma nova espécie foi o ápice do fruto inciso, característica que também ocorre em $P$. coccinea.

A distribuição de $P$. coccinea está restrita ao sul do Pará, norte de Mato Grosso e Tocantins, neste último estado ocorrendo na Ilha do Bananal, na divisa entre Mato Grosso e Pará.

3. Pera decipiens Müll. Arg., Linnaea 34: 201. 1865. Tipo: GUIANA INGLESA. 1842, fl., Rich Schomburgk 1070 (lectótipo K, designado por Gillispie (1993); isolectótipo G, K, W; foto G!, K!), 1071 (síntipo K; foto K!).

Fig. 4

Pera nitida (Benth) Jablonski, Memoirs of the New York Botanical Garden 1:148. 1967. Peridium bicolor var. nitidum Benth., Jour. Bot. \& Kew Misc. 6:323. 1854. Tipo: GUIANA INGLESA. 1842, fl., Rob. Schomburgk. 685 e 686 (síntipo K; foto K!); GUIANA INGLESA. 1842, fl., Rich Schomburgk 1070 (lectótipo K, designado por Gillispie (1993); isolectótipo $\mathrm{G}, \mathrm{K}, \mathrm{W}$; foto, G!, $\mathrm{K}$ !), 1071 (síntipo $\mathrm{K}$; foto do tipo $\mathrm{K}$ !).

Arvoreta ou árvore dioicas. ca. 5-19 m alt. $\times$ 10-40 cm diâm. Ramos lepidotos, tricomas lepidotos. Folhas alternas, peninérveas, nervuras pouco proeminentes em ambas as faces, $3-16,5 \mathrm{~cm}$ compr. $\times 1,5-5 \mathrm{~cm}$ larg., elíptico-oblongas a elípticolanceoladas, coriáceas, margem inteira, base cuneada a arredondada, ápice agudo; face adaxial lepidota, tricomas lepidoto-estrelados concentrados na nervura principal; face abaxial denso-lepidota, tricomas lepidoto-estrelados, emaranhados; glândulas ausentes; pecíolo 0,5-2 cm compr., canaliculado, lepidoto, tricomas lepidotos. Inflorescências pseudantos axilares, fasciculados, unissexuadas, lepidotas, tricomas lepidoto-estrelados; pedúnculo 1,2-7 mm compr., denso-lepidoto, tricomas lepidotoestrelados; bractéolas 2, 0,8-1 mm diâm. na base do invólucro, orbiculares, opostas, denso lepidotas, tricomas lepidoto-estrelados; invólucro globoso, coriáceo, denso-lepidoto, tricomas lepidotos, o das flores estaminadas estaminadas 3-5 mm diâm., o das flores pistiladas $0,5-1 \mathrm{~cm}$ diâm., ambos abrindo-se por uma fenda longitudinal na antese. Flores estaminadas sésseis, cálice campanulado, 

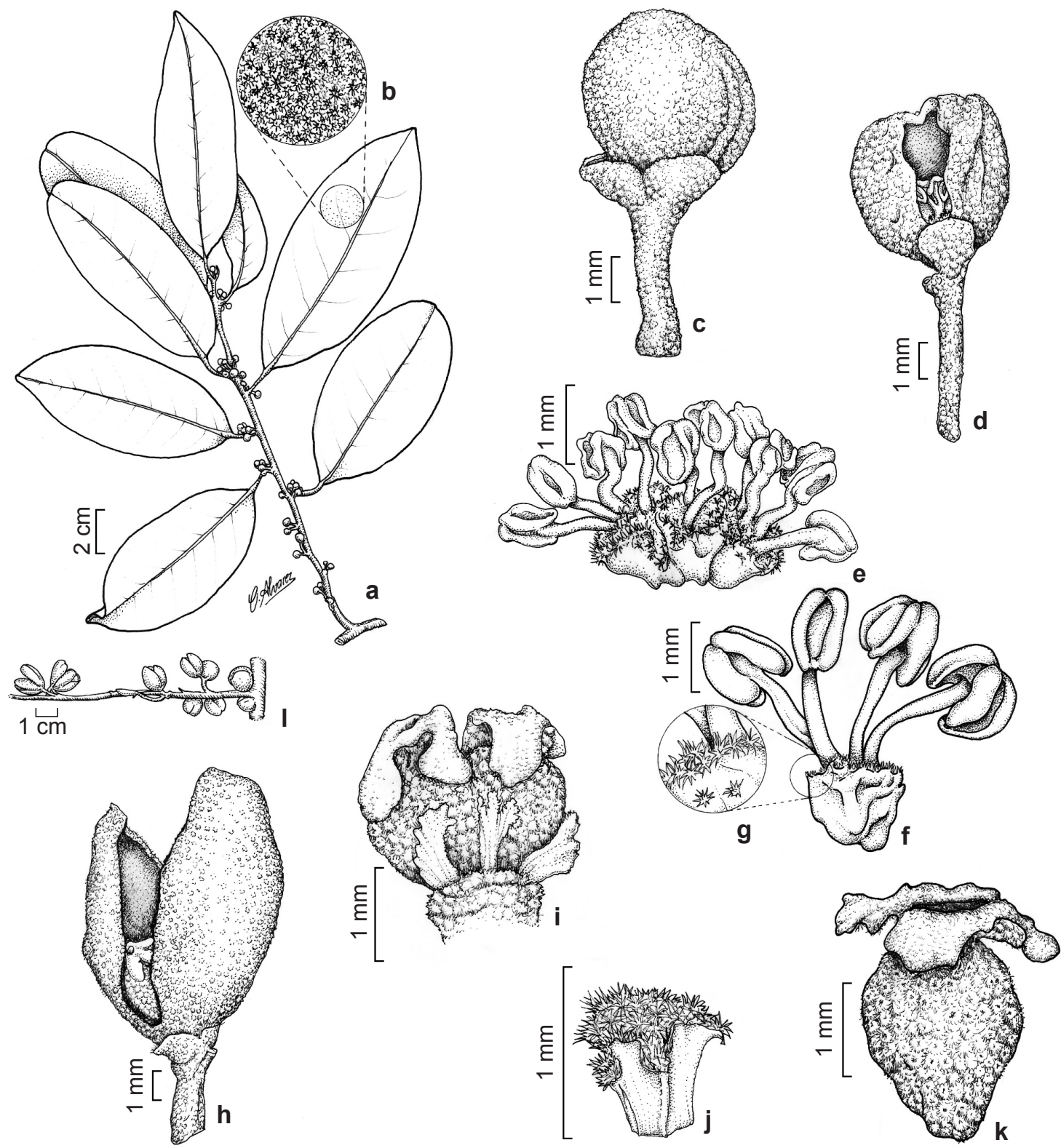

Figura 4-Pera decipiens Müll. Arg. - a. ramo com inflorescências estaminadas; b. detalhe da face abaxial denso-lepidota com tricomas lepidoto-estrelados; c. inflorescência na pré-antese, evidenciando as brácteas opostas na base do invólucro; d. inflorescência estaminada abrindo-se por uma fenda longitudinal na antese; e. três flores estaminadas com invólucro removido; f. detalhe da flor estaminada com cálice campanulado; g. detalhe da margem do cálice ciliado com tricomas simples; h. inflorescência pistilada abrindo-se na antese por uma fenda longitudinal; i. duas das quatro flores pistiladas mostrando os três estaminódios sepalóides centrais; j. estaminódio sepalóide; k. flor pistilada com estigma 3-lobado; 1. ramo com frutos. (a-e J.M. Pires et. al. 1983; f-g C.A. Cid Ferreira 9587; h J.M. Pires et al. 1562; i-1 J.S. Rodrigues et al. 54).

Figure 4-Pera decipiens Müll. Arg. - a. branch with staminate inflorescences; b. details of dense lipidote leaf lower surface with lepidote-starred trichomes; c. pre-anthesis inflorescence, showing two bracts at the base of the involucre, opposite; d. staminate inflorescence opening by a longitudinal slit at anthesis; e. three staminate flowers with involucre removed; $f$. detail of staminate flower with campanulate calyx; g. detail of ciliate calyx margin with simple trichomes; h. pistillate inflorescence opening by a longitudinal slit at anthesis; i. two pistilate flowers showing three central sepaloid staminodia; j. sepaloid staminodium; k. pistillate flower with 3-lobed stigma; 1. branch with fruit. (a-e J.M. Pires et. al. 1983; f-g C.A. Cid Ferreira 9587; h J.M. Pires et al. 1562; i-1 J.S. Rodrigues et al. 54). 
3-lobado, lobos 1-1,5 mm compr., concrescidos na base, ápice lacerado, ciliado, tricomas simples, glabro internamente; estames 3-4 por flor, 2-3 $\mathrm{mm}$ compr., filetes concrescidos na base, glabros, anteras ca. 0,5 mm compr., pistilódio ausente. Flores pistiladas subsésseis, pedicelo $0,2-0,3 \mathrm{~mm}$ compr., ovário 1,5-2,0 mm diâm., piriforme, densolepidoto, tricomas lepidotos, estilete séssil, estigma trífido, lobos inteiros, 0,6-1 cm compr., face abaxial denso-lepidota, tricomas lepidotos, a adaxial glabra, papilosa, estaminódio sepaloides, 3 , centrais, $0,6-0,8$ mm compr. $\times 0,2-0,4 \mathrm{~mm}$ larg., cuneiforme, lepidoto, tricomas lepidoto-radiados, estaminódio filiforme ausente. Fruto ca. $1,2 \mathrm{~cm}$ compr. $\times$ ca. $1 \mathrm{~cm}$ diâm., subgloboso, rugoso, esparso-lepidoto, tricomas lepidotos, pedicelo $0,4-1 \mathrm{~cm}$ compr. Sementes ca. $6 \mathrm{~mm}$ compr. $\times$ ca. $4 \mathrm{~mm}$ larg., ovóides, base obtusa, ápice arredondado, carúncula alaranjada, cobrindo $2 / 3$ da semente.

Material selecionado: ACRE: Rio Branco, Tuvumu Terra de Mairavy, II.1909, fl. (đ) ), E. Ule 8409 (MG); Caracaraí, 7.I.1929, fl., J.G.. Kulhmann 1073 (RB); Bela Vista, 19.III.30, fl., J.G. Kulhmann 3145 (RB). AMAZONAS: Maués, rio Maués, 17.XI.1977, fl. (đ), N.T. da Silva 4497 (MG); Humaitá para Lábrea, 63km W de Humaitá, campina, $7^{\circ} 30^{\prime} \mathrm{S} 63^{\circ} 31^{\prime} \mathrm{W}, 30 . \mathrm{IX} .1979$, fl. (ठ), J.L. Zarucchi et al. 2605 (MG, RB); rio Urubu, 10.VI.1968, G.T. Prance et al. 5117 (MG); Rodovia do Estanho, $150 \mathrm{~km}$ de Humaitá; campina, $8^{\circ} 7^{\prime}$ S 61ํำ'W, 25.IX.1979, G. Vieira et al. 153 (RB); Parintins, Lago do Juruti, 20.I.1952, fr., R. L. Froés 33095 (IAN); rio Negro, Ilha Carambana, 10.II.1959, fr., José S. Rodrigues 54 (UB, IAN); Basin rio Negro, Tapuruquara, 21.X.1971, fl., G.T. Prance et al. 15755 (MG); BR 319, km 378, estrada Manaus - Porto Velho, on bank of rio Jutaí, 15.X.1974, fl. (đ), G.T. Prance et al. 22933 (MG); Barcelos, rio Jauari, $0^{\circ} 42^{\prime} \mathrm{N}$ $63^{\circ} 22^{\prime}$ W, 2.VII.1985, fr., J.A. Silva 225 (MG); Almerim, Monte Dourado Bloco Caracurú, prox. Gleba Angelim, 23.XII.1986, fl.(P), J.M. Pires 1562 (MG). PARÁ: Área de Mineração Rio Norte. Lago da Batata, $1^{\circ} 30^{\prime}$ 'S 56 $20^{\circ}$ 'W, Mata de Igapó, 13.XI.1987, fl. (đ), C.A. Cid Ferreira 9587 (MG, RB); Oriximiná, rio Cachorro, 20.VI.1980, fl. (ㅇ), Martinelli 7208 (MG); Monte Dourado, Gleba Angelim,

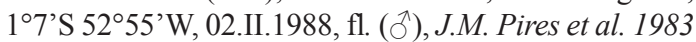
(MG); rio Parú do Oeste, Missão Tiriyo, $2^{\circ} 20^{\prime} \mathrm{N} 55^{\circ} 45^{\prime} \mathrm{W}$, 23.II.1970, fr., P. Cavalcante 2478 (MG); rio Marapí, 17.X.1974, fl., N.A. Rosa 229 (RB, IAN); rio Arapiuns, Lago Mentái, 11.XI.1952, fl., J.M. Pires et al. 4361 (IAN); Faro, Fazenda Santa Olímpia, campina, 6.XI.1950, fl., G.A. Black et al. 50-10628 (IAN); Conceição, rio Juruena, 13.I.1952, fr., J.M. Pires 3910 (IAN); Santarém, Curuatinga, mata primária, 18.II.1955, fr., R.L. Froés 31556 (IAN); Lago Preto de Jurutí, várzea, 20.I.1957, fr., E. Oliveira 28 (IAN); Óbidos, $91 \mathrm{~km}$ de Oriximiná, campos de Ariramba, $1^{\circ} 10^{\prime} \mathrm{S}, 55^{\circ} 35^{\prime} \mathrm{W}, 4 . X \mathrm{XI} .1987$, fr., C.A. Cid Ferreira 9739 (MG). RONDÔNIA: Guaporé, rio das Garças, 27.XI.1949, fl. (), N.T. Silva 372 (IAN); km. 217-9 Madeira-Mamoré railroad, 18.XI.1968 fr., G.T. Prance et al. 8594 (MG). RORAIMA: Boa Vista, estrada Surumu, rio Paricarana, savana estépica, 1.V.1979, fl. (đ), I.A. Rodrigues et al. 774 (IAN); próximo a boca do Igarapé, rio Surumú, 23.VI.1974, fr., J.M. Pires et al. 14619 (MG); rio Uraricoera, Serra Cura-ci-ha, 633' 'W, fr., J.M. Pires et al. 16941 (MG); Caracaraí, estrada Perimetral Norte (BR-210), próx. a Novo Paraíso, $0^{\circ} 15^{\prime} \mathrm{N}$ 60²7’W, 26.VIII.1987, fr., C.A. Cid Ferreira 9198 (MG). Material adicional: GUIANA, Kamoa River: toucan Mountain, forest, $1^{\circ} 33^{\prime} \mathrm{N} 58^{\circ} 50 \mathrm{~W}, 22 . \mathrm{IX} .1989$, fl., M.J. Jansen-Jacobs et al. 1751 (MG).

Distribuição geográfica: Brasil (Roraima, Amazonas, Acre, Pará, Rondônia e Mato Grosso), Colômbia, Guiana Inglesa, Suriname, Guiana Francesa, Peru (Gillespie 1993).

Entre as espécies de Pera sect. Neopera, $P$. decipiens está mais próxima de $P$. tomentosa, e às vezes podem ser confundidas em material desidratado, pois as duas apresentam uma coloração amarelada na face abaxial das folhas. Entretanto, a um olhar mais atento, percebe-se que $P$. decipiens possui nervuras proeminentes, com tricomas lepidotoestrelados; ovário piriforme, com tricomas lepidotoestrelados; estaminódio sepalóide cuneiforme e ausência de estaminódio externo.

Outros detalhes sobre $P$. decipiens podem ser encontrados nos comentários de $P$. bicolor, bem como nas considerações de Gillespie \& Armbruster (1997) para a mesma espécie.

Essa espécie parece ocorrer em quase toda a região amazônica, com exceção do estado do Amapá, e provavelmente esta ausência deva-se à falta de coletas naquele estado. Nos estados de Roraima, do Acre e Mato Grosso, P. decipiens está sendo assinalada pela primeira vez.

4. Pera manausensis Bigio \& Secco, Rodriguésia 61(1): 77-81. 2010. Tipo: BRASIL. AMAZONAS. Manaus, Reserva Ducke, Estrada Manaus-Itacoatiara, $\mathrm{km} \mathrm{26}$, entrada do alojamento-torre, $\mathrm{km} \mathrm{35}$, 22.IV.1995, fl.(ㅇ), A. Vicentini et al. 1058 (holótipo MG!; isótipos INPA!, SP!, UB!). $\quad$ Fig. 5

Árvore dióica ca. $25-35 \mathrm{~m}$ alt. $\times$ ca. $30 \mathrm{~cm}$ diâm. Ramos lepidotos, tricomas estrelado-lepidotos. Folhas alternas, peninérveas, nervuras proeminentes na face abaxial, 8-12,5 × 4,5-6,5 cm, elíptico-oblongas, coriáceas, margens inteiras, base cuneada, ápice obtuso a arredondado; face adaxial glabra, nervura principal pubescente, tricomas estrelados; face abaxial denso-lepidota, tricomas lepidoto-estrelados, emaranhados; glândulas ausentes; pecíolo 1-1,5 cm compr., canaliculado, lepidoto, tricomas lepidotos. 
Inflorescências pseudantos axilares, fasciculados, unissexuadas, lepidotas, tricomas lepidoto-estrelados; pedúnculo $0,5-1 \mathrm{~cm}$ compr., lepidoto, tricomas lepidoto-estrelados; bractéolas 2, 1-3 mm compr. diâm. na base do invólucro, orbiculares, opostas, lepidotas, tricomas lepidoto-estrelados; invólucro globoso, coriáceo, lepidoto, tricomas lepidotoestrelados, o das flores estaminadas 3-5 mm diâm., o das flores pistiladas 5-6 mm diâm., ambos abrindo-se por uma fenda longitudinal na antese. Flores estaminadas sésseis, cálice campanulado, 3-lobado, lobos 0,5-1,3 mm compr., ápice lacerado, esparso-seríceo, tricomas simples; estames 3-4 por flor, 1,5-2,5 mm compr., filetes concrescidos na base, 0,5-1 mm, glabros, anteras 1-1,5 mm compr., pistilódio desenvolvido (rudimento de flor pistilada) ausente, pistilódio filiforme, ca. $1 \mathrm{~mm}$ compr., esparso-pubscente, tricomas simples. Flores pistiladas pediceladas, pedicelo 0,6-1,2 mm compr., ovário 4-5 mm diâm., globoso, tomentoso, tricomas simples, estilete séssil a subséssil, 0,2 mm compr., estigma trífido, lobos bipartidos, 3-4 mm compr., face abaxial tomentosa, tricomas estrelados, face adaxial glabra, papilosa, estaminódios sepalóides 1-2, centrais, 1-2 $\times$ 0,3-1,2 mm, disformes, lacerados, esparso seríceo a ciliado, tricomas simples, estaminódio filiforme 1, 1-1,2 mm compr., pubscente, tricomas simples. Fruto 1-1,2 × 1-1,2 cm, globoso, rugoso, tomentoso, tricomas estrelados, pedúnculo 5-7 $\mathrm{mm}$ compr. Sementes imaturas.

Material selecionado: Parátipos. AMAZONAS: Manaus, Reserva Ducke, Estrada Manaus-Itacoatiara, km 26, estrada alojamento-torre, km 35, 5.XII.1995, fr., M.A.S. Costa et al. 433 (MG); Distrito Agropecuário, 90 km NNE de Manaus, reserva $1501(\mathrm{~km} 41)$, projeto dinâmica Biológica de fragmentos florestais, 2 24 ' $26^{\prime}$ 'S $59^{\circ} 43$ ' 40 ' $\mathrm{W}$, 21.XI.1991, fl.(ð), A.A. Oliveira et al. 245 (INPA).

Distribuição geográfica: endêmica da Amazônia Central, estado do Amazonas.

Fenologia: floresce de junho a novembro e frutifica em dezembro.

Os dois espécimes (Vicentini et al. 1058 e Costa et al. 433) provenientes da Reserva Ducke foram coletados da mesma árvore, que está marcada com o número 3304-11 e apresentava-se identificada como Pera schomburgkiana Müll. Arg. Esta espécie é sinônimo de P. bicolor (Kloztsch) Müll. Arg. Desta forma, são conhecidos somente dois indivíduos contendo flores, um com flor pistilada (da Reserva Ducke) e outro com flor estaminada (do Distrito Agropecuário de Manaus).

$\mathrm{O}$ indumento da face abaxial das folhas de Pera manausensis é similar ao de $P$. decipiens
Müll. Arg., já que ambas possuem tricomas lepidotos-estrelados. Mas separam-se prontamente, pois $P$. manausensis tem ovário com indumento tomentoso, de tricomas simples, enquanto em $P$. decipiens o ovário é piriforme, com tricomas lepidoto-estrelados; além disso, $P$. manausensis tem nervuras mais proeminentes que em $P$. decipiens.

A flor pistilada de $P$. manausensis assemelhase muito a de Pera bicolor, já que em ambas o ovário é tomentoso, com estigma 3-lobado, lobos bipartidos, além da presença de estaminódios, devendo ser por isso a identificação equivocada que vinha recebendo como $P$. schomburgkiana (sinônimo de P. bicolor). Mas P. manausensis possui folhas com tricomas lepidoto-estrelados na face abaxial, cálice das flores estaminadas 3-lobado, campanulado e pistilódio filiforme; já $P$. bicolor tem a face abaxial das folhas com tricomas estrelados, cálice das flores estaminadas lacerado, disforme e ausência de pistilódio.

A presença de ovário tomentoso também aproxima $P$. manausensis de $P$. tomentosa. Mas desta se separa facilmente pela face abaxial das folhas com indumento de tricomas lepidotoestrelados, flores pistiladas com estigma 3-lobado, lobos bipartidos e flores estaminadas com pistilódio filiforme. Em $P$. tomentosa a face a abaxial das folhas possui denso indumento de tricomas estrelados, flores pistiladas com estigma 3-lobado, lobos inteiros e ausência de pistilódio.

Por ter o invólucro da inflorescência abrindose através de uma fenda longitudinal na antese, flores estaminadas com pistilódio e flores pistiladas com estaminódios, Pera manausensis deve ser posicionada em Pera sect. Neopera Griseb.

Pera manausensis é a segunda espécie endêmica conhecida para a região de Manaus, a primeira é Pera pulchrifolia Ducke, que pode ser facilmente reconhecida pelas folhas opostas.

5. Pera pulchrifolia Ducke, Tropical Woods 50: 36. 1937. Tipo: BRASIL. AMAZONAS. Manaus, atrás da lagoa Pensador, 25.X.1935 fl. (ð̊), Ducke 241 (lectótipo RB!, aqui designado; isolectótipos NY, MO); AMAZONAS. Manaus, mata de terra firme da estrada do Aleixo, perto de um riachinho, 29.VIII.1935, fl. ()), Ducke s/n (síntipos, RB 29036!, NY 272999, MO 1158940; foto NY!, $\mathrm{MO} !)$.

Fig. 6

Árvores dióicas, 6-15 m alt. Ramos glabrescentes, denso-tomentosos, tricomas estrelados. Folhas opostas, peninérveas, nervuras 


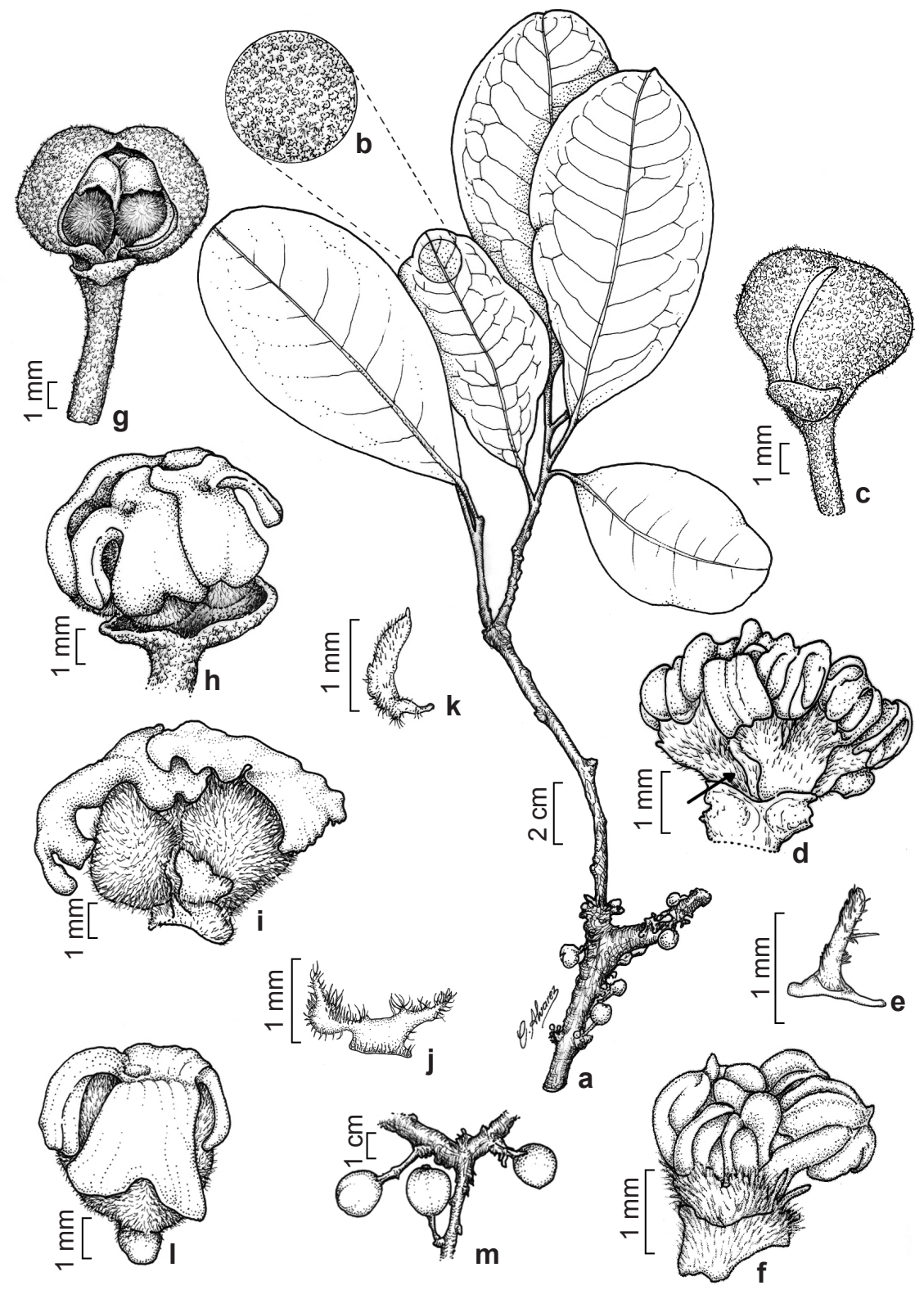

Figura 5 - Pera manausensis Bigio \& Secco - a. ramo com inflorescências; b. detalhe da face abaxial lepidota com tricomas lepidoto-estrelados; c. inflorescência estaminada abrindo-se por uma fenda longitudinal na antese; d. três flores estaminadas com invólucro removido e com um pistilódio externo; e. pistilódio filiforme; f. flor estaminada com cálice seríceo com tricomas simples; g. inflorescência pistilada abrindo-se por uma fenda longitudinal na antese; $\mathrm{h}$. quatro flores pistiladas, com invólucro removido e duas brácteas opostas na base; i. duas flores pistiladas mostrando o estaminódio sepalóide central e o estaminódio filiforme externo; j. estaminódio sepalóide; k. estaminódio filiforme externo; 1. flor pistilada com estigma 3-lobado bipartido; m. frutos imaturos. (a-b, g-h, j-1 A. Vicentini et al. 1058; c-f A.A. Oliveira et al. 245; i A.S. Costa et al. 433).

Figure 5 - Pera manausensis Bigio \& Secco - a. branch with pistillate inflorescence; b. detail of lower surface lepidote with trichomes lepidote-stellate; c. staminate inflorescence opening by a longitudinal slit at anthesis; $d$. three staminate flowers without involucral bract and one external pistilodium (arrow); e. detail of the filiform pistillodium; f. detail of staminate flower with indument of simple trichomes on the calyx; g. pistillate inflorescence with a longitudinal opening at anthesis; h. four pistillate flowers without the involucral bract, opposite bracteole at the base; i. two pistillate flowers, central sepaloid staminodium and the external filiform staminodium; j. detail of the sepaloid staminodium; $\mathrm{k}$. detail of the filiform staminodium; 1. pistillate flower with 3-lobed stigma with bifid lobes; $\mathrm{m}$. fruits. (a-b,g-h, j-1 A. Vicentini et al. 1058; c-f A.A. Oliveira et al. 245; i Costa et al. 433). 
proeminentes na face abaxial, $23-40 \mathrm{~cm}$ compr. $\times 10-14,5 \mathrm{~cm}$ larg., elíptico-ovadas ou oblongas, coriáceas, margem inteira, base obtusa a arredondada, ápice acuminado a quase mucronado; face adaxial glabra, nervura principal tomentosa, tricomas estrelados; face abaxial denso-tomentosa, tricomas estrelados, glândulas ausentes; pecíolo $1-2 \mathrm{~cm}$ compr., canaliculado, denso-tomentoso, tricomas estrelados. Inflorescências pseudantos axilares, fasciculados, unissexuadas, tomentosas, tricomas estrelados; pedúnculo 0,4-1,2 cm compr., tomentoso, tricomas estrelados; bractéolas 2, 1-3 mm diâm. na base do invólucro, orbiculares, opostas, tomentosa, tricomas estrelados; invólucro subgloboso, coriáceo, tomentoso, tricomas estrelados, o das flores estaminadas $0,4-8 \mathrm{~mm}$ diâm. $\mathrm{x}$ 0,3-1 cm compr., o das flores pistiladas $3-8 \mathrm{~mm}$ diâm. $\mathrm{x}$ 0,5-1 cm compr., ambos abrindo-se por uma fenda longitudinal. Flores estaminadas pediceladas, pedicelo ca. $0,4 \mathrm{~mm}$, cálice campanulado, 3-lobado, lobos 0,3-0,4 mm compr., concrescidos na base, ápice lacerado, tomentoso, tricomas estrelados; estames 3-4, 3-4 mm compr., filetes concrescidos na base, glabros, anteras, $0,5-1$ $\mathrm{mm}$ compr., pistilódio desenvolvimento (rudimento de flor pistilada) ausente, pistilódio filiforme externo ca. $1 \mathrm{~mm}$ de compr., filiforme, pubscente, tricomas simples. Flores pistiladas subsésseis, pedicelo $0,2-1 \mathrm{~mm}$ compr., ovário 1-2 mm diâm., globoso, tomentoso, tricomas estrelados, estilete séssil, estigma trífido, lobos inteiros, $1-2 \mathrm{~mm}$ compr., face abaxial seríceo-tomentosa, face adaxial papilosa, estaminódio sepalóide 3, 0,5-1 mm compr., cuneiforme, ciliado, tricomas simples, estaminódio filiforme ausente. Fruto $1-1,5 \mathrm{~cm}$ diâm. $\times 1,2-1,5 \mathrm{~cm}$ compr., triangular a subgloboso, dilatado, tomentoso, tricomas estrelados. Sementes 5-7 mm compr. $\times 3-4$ $\mathrm{mm}$ larg., ovóides, base obtusa, ápice arredondado, carúncula alaranjada, cobrindo $1 / 3$ da semente.

Material selecionado: AMAZONAS: Manaus, mata de terra firme, estrada do Aleixo, 13.XII.1935, fr., Ducke $s / n$ (RB 29036!); igarapé do Parque 10 de novembro, 6.I.1956, fr., J. Chagas s/n (INPA 3286); Cachoeira alta do Tarumã, 21.XI.1961, fr., $W$. Rodrigues \& $J$. Chagas 3698 (INPA); estrada velha de São Raimundo, 24.X.1958, fl. (ㅇ), D. Coelho s/n (INPA 6743).

Distribuição geográfica: Brasil, no estado do Amazonas.

Pera pulchrifolia separa-se de $P$. benensis e $P$. oppositifolia por apresentar a face abaxial das folhas com indumento tomentoso de tricomas estrelados, sendo que na face adaxial este indumento é encontrado apenas na nervura principal. Além disso, em Pera pulchrifolia as folhas são maiores, o pecíolo menor e há cálice nas flores estaminadas.
Ducke (1937) informou que $P$. pulchrifolia lembra algumas espécies de Vismia Vand. (Clusiaceae) ou Eugenia L. (Myrtaceae), com folhas grandes, mas os caracteres morfológicos vistos comprovam o táxon como pertencente a Pera. O epíteto específico (pulchrifolia) foi dado em homenagem à beleza das folhas, que no material seco apresenta uma coloração avermelhada. Além disso, o tamanho avantajado das folhas chama a atenção.

6. Pera tomentosa (Benth.) Müll. Arg., in DC., Prodr. 15(2): 1028. 1866. Peridium bicolor var. tomentosum Benth., Hooker J. Bot. Kew Gard. Misc. 6: 323. 1854. Tipo: BRASIL. AMAZONAS. prope Barra, prov. rio-Negro, X.1851, Spruce 1820 (lectótipo K, designado por Gillespie (1993); isolectótipos G, NY, P; foto G!, NY!, K!, P!).

Fig. 6

Pera cinerea Baill., Adansonia 5: 223. 1865, nom. nud.

Spixia cinerea Poepp. In Sched. Tipo: BRASIL. AMAZONAS. s.d. Ega, Poeppig 2640 (isótipos P, $\mathrm{G}, \mathrm{L}, \mathrm{W}$; foto L!)

Peridium cinereum Poepp. In sched.

Arvoreta ou árvore dióicas, $12-25 \mathrm{~m}$ alt. $\times$ 15-40 cm diâm.. Ramos tomentosos, com tricomas estrelados ou glabros. Folhas alternas, peninérveas, nervuras pouco proeminentes na face abaxial, 4-11,5 cm compr. $\times 2,5-5,5 \mathrm{~cm}$ larg., elípticas a elíptico-lanceoladas, coriáceas, margem inteira, base cuneada a arredondada, ápice arredondado a agudo ou acuminado; face adaxial glabra, nervura principal tomentosa, tricomas estrelados; face abaxial denso-tomentosa, tricomas estrelados, emaranhados; glândulas ausentes; pecíolo $0,3-0,8 \mathrm{~cm}$ compr., canaliculado, denso-tomentoso, tricomas estrelados. Inflorescências pseudantos axilares, fasciculados, unissexuadas, tomentosas, tricomas estrelados; pedúnculo 5-7 $\mathrm{mm}$ compr., tomentoso, tricomas estrelados; bractéolas 2, ca. $1 \mathrm{~mm}$ diâm. na base do invólucro, orbiculares, opostas, tomentosas, tricomas estrelados; invólucro globoso, coriáceo, tomentoso, tricomas estrelados, o das flores estaminadas ca. $3 \mathrm{~cm}$ diâm., o das flores pistiladas $0,5-1 \mathrm{~cm}$ diâm., ambas abrindo-se por uma fenda longitudinal na antese. Flores estaminadas sésseis, cálice campanulado, 3-lobulado, lóbos de 0,5-1,2 mm compr., cálice concrescido na base, ápice lacerado a denteado, esparso-seríceo, tricomas simples; estames 3 por flor, 1,5-2,5 mm compr., filetes concrecidos na base, glabros, anteras $0,7-1 \mathrm{~mm}$ compr., pistilódio ausente. Flores pistiladas sésseis a subsésseis, ca. 0,3mm compr., ovário 1-1,5mm diâm., globoso, denso-tomentoso, tricomas estrelados, estilete séssil, 

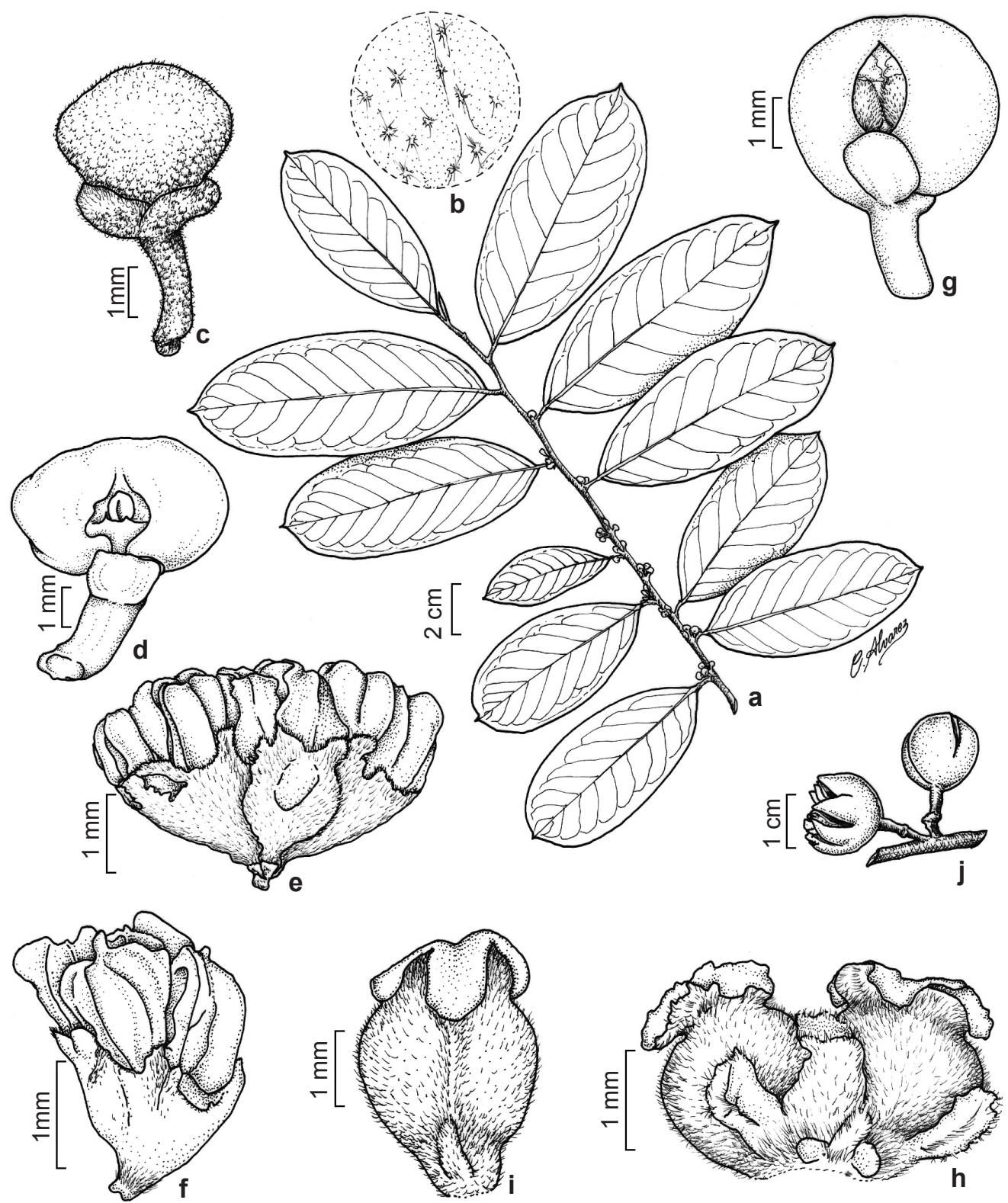

Figura 6 - Pera tomentosa (Benth.) Müll. Arg. - a. ramo com inflorescências imaturas; b. detalhe da face abaxial da folha com indumento de tricomas estrelados; c. inflorescência em pré-antese, evidenciando as brácteas opostas na base do invólucro; d. inflorescência estaminada abrindo-se por uma fenda longitudinal na antese; e. três flores estaminadas com invólucro removido; f. flor estaminada com cálice campanulado; g. inflorescência pistilada abrindo-se por uma fenda longitudinal na antese; h. duas das quatro flores pistiladas mostrando os três estaminódios sepalóides centrais e um estaminódio filiforme externo; i. flor pistilada com estigma 3-lobado e ovário denso-tomentoso de tricomas estrelados; j. frutos. (a-b C.A.A. Freitas et al. 564; c-f J.M.S. Miralha et al. 305; g-i A. Ducke (RB 35676); j G.T. Prance et al. 7747).

Figure 6-Pera tomentosa (Benth.) Müll. Arg. - a. stem with immature inflorescences; b. leaf detail of dense tomentose lower surface with stellate trichomes; c. pre-anthesis inflorescence, showing two opposite bracts at the base; d. staminate inflorescence opened by a longitudinal slit at anthesis; e. three staminate flowers with involucre removed; f. staminate flowers with campanulate calyx; g. pistillate inflorescence opened by a longitudinal slit at anthesis; h. two pistillate flowers showing the three central sepaloid staminodea, one filiforme external staminodium; i. pistillate flower with 3-lobed stigma and dense tomentose ovary with stellate trichomes; $\mathrm{j}$. fruits. (a-b C.A.A. Freitas et al. 564; c-f J.M.S. Miralha et al. 305; g-i A. Ducke (RB 35676); j G.T. Prance et al. 7747). 

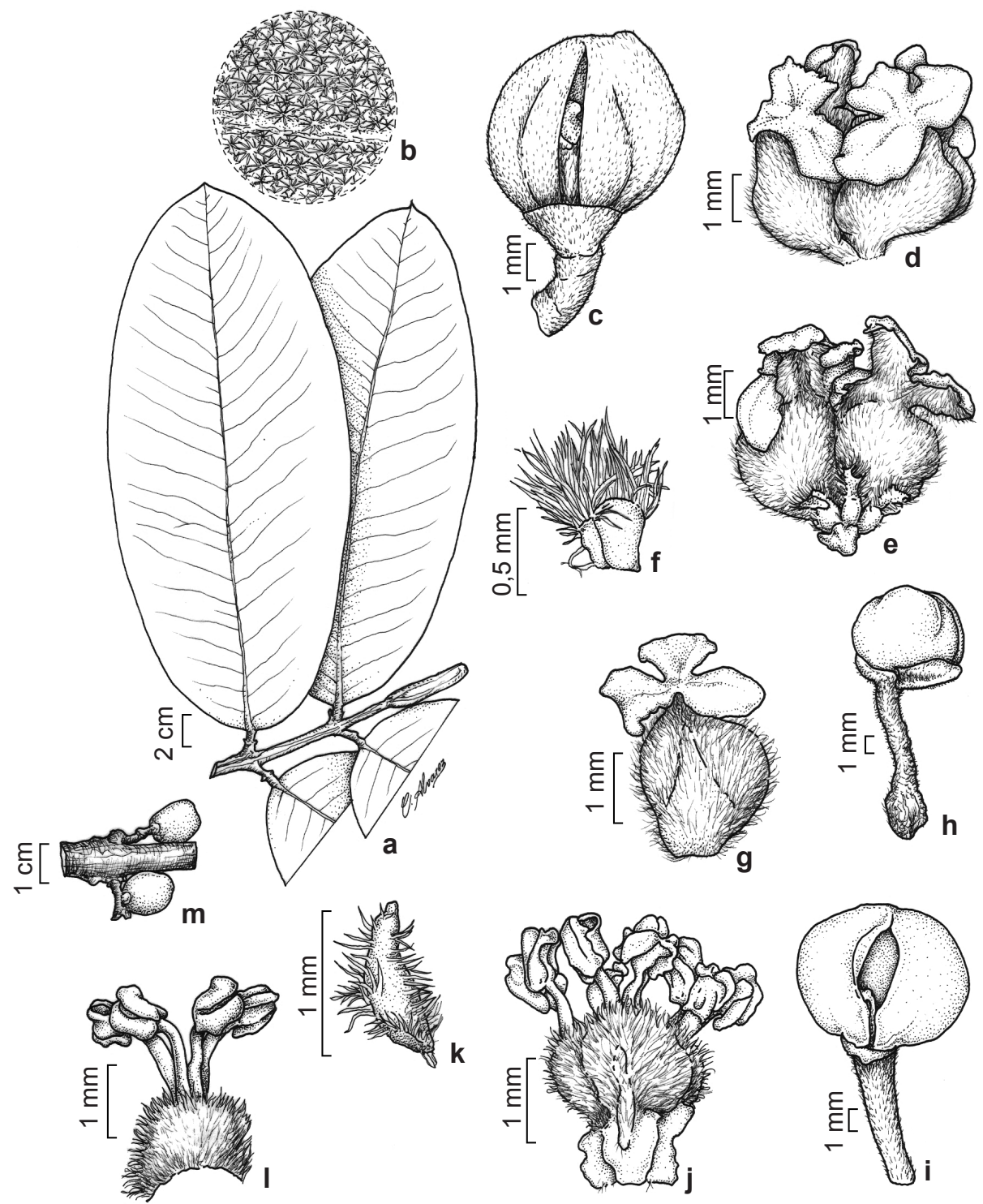

Figura 7 - Pera pulchrifolia Ducke - a. ramo mostrando as folhas opostas; b. detalhe da face abaxial da folha com indumento tomentoso de tricomas estrelados; c. inflorescência pistilada abrindo-se por uma fenda longitudinal na antese; d. inflorescência pistilada com invólucro removido, mostrando quatro flores pistiladas; e. duas das quatro flores pistiladas evidenciando os três estaminódios na base das flores; f. estaminódio sepalóide ciliado com tricomas simples; g. flor pistilada tomentosa de tricomas estrelados; h. inflorescência estaminada imatura mostrando as duas brácteas opostas; i. inflorescência estaminada abrindo-se por uma fenda longitudinal na antese; j. inflorescência estaminada com invólucro removido, mostrando o pistilódio filiforme; $\mathrm{k}$. pistilódio filiforme, com tricomas esparsos; 1 . flor estaminada com cálice tomentoso; m. frutos imaturos. (a-h, l-m A. Ducke (RB 29036); i-k D. Coelho (INPA 6743)). Figura 7 - Pera pulchrifolia Ducke - a. stem showing opposite leaves; b. leaf detail of the lower tomentose surface with stellate trichomes; c. pistillate inflorescence opened by a longitudinal slit at anthesis; d. Pistillate inflorescence with involucre removed, showing four pistillate flowers; e. two pistillate flowers showing three staminodia at the base of flowers; f. sepaloid staminodium ciliate with simple trichomes; g. pistillate tomentose flower with stellate trichomes; h. immature staminate inflorescence showing two opposite bracts; i. staminate inflorescence opened by a longitudinal slit at anthesis; j. staminate inflorescence with involucre removed, showing the filiform pistilodium; $\mathrm{k}$. filiform pistilodium pubescent with sparse simple trichomes; 1 . staminate flower with tomentose calyx; $\mathrm{m}$. immature fruits. (a-h, l-m A. Ducke (RB 29036); i-k D. Coelho (INPA 6743)). 
estigma trífido, lobos inteiros, 0,8-1 mm compr., face abaxial tomentosa, tricomas estrelados, a adaxial glabra, papilosa, estaminódios sepalóides 3, 0,4-7 mm compr., filiformes, seríceo e ciliados, tricomas simples, estaminódio filiforme externo 1, 0,8-1 mm compr., denso tomentoso, tricomas estrelados. Fruto ca. 1,3 cm diâm. $\times 1,0$ cm compr., subgloboso, rugoso, denso-tomentoso, tricomas estrelado-tomentosos. Sementes 3-5 mm compr. × 2-4 mm larg., ovóides, base otusa, ápice arredondado, carúncula alaranjada, cobrindo 2/3 da semente.

Material selecionado: AMAZONAS: rio Uaupés, Panuré, caatinga, 15.XI.1947, fl.() e fr., J. Murça Pires 1039 (IAN); Manaus, 25.X.1936 (fl. O), A. Ducke (RB 35676); Manaus, Estrada do Aleixo, capoeira, 9.VIII.1943 (fl. §) A. Ducke 2082 (IAN); Tefé, 30.IX.1947, fr. G.A. Black 47-1564 (IAN); Reserva Ducke, floresta de Platô, 12.X.1995, fl.(ठ̊), J.M.S. Miralha et al. 305 (IAN, MG); rio Negro, XII.1854, fl.(q), R. Spruce 3774 (MG); São Gabriel da Cachoeira, rio Negro, 11.XI.1997, fl., C.A.A. Freitas et al. 564 (INPA). ACRE: Sena Madureira, rio

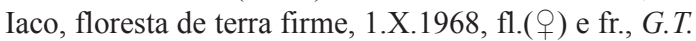
Prance et al. 7747 (MG). MATO GROSSO: Aripuanã, km 238 da BR-174, mata de terra firme, 16.I.1979, fr., M.G. Silva et al. 4294 (MG, RB).

Material adicional: VENEZUELA. Amazonas, prope Esmeralda: ad flumen Orenoco, XII.1853, fl., Spruce 3219 (RB).

Distribuição geográfica: Brasil (Amazonas, Acre e Mato Grosso), Venezuela, Peru, Bolívia (Gillespie 1999).

Silva Alves (1993) separou Pera cinerea de $P$. tomentosa, apontou lectótipo para $P$. cinerea, com base em Poeppig 2640, mas manteve P. tomentosa como sinônimo de $P$. bicolor, sendo que analisou somente o tipo de P. bicolor.

Gillespie (1993) analisou as coleções Spruce 1820 e Schomburgk 114, constatando que se tratavam de dois espécimes discordantes, que eram referidos como os tipos de Peridium bicolor var. tomentosum e, desta forma, utilizou o mesmo conceito de Müller (1866) e Lanjouw (1931), mantendo Pera tomentosa também como espécie válida, cujo lectótipo seria Spruce 1820; para P. bicolor, considerou como tipo a coleção Schomburgk 114. Para mais informações verifique os comentários de P. bicolor e Gillespie \& Armbruster (1997).

Entretanto, $P$. tomentosa separa-se de $P$. bicolor pelas folhas, cuja face abaxial tem indumento tomentoso de tricomas estrelado, além das flores estaminadas com cálice 3-lobado, os lóbulos com 0,5-1,2 $\mathrm{mm}$ de comprimento e a margem denteada; o indumento do cálice é de tricomas simples, esparso; as flores pistiladas têm estigma trífido, inteiro, 3 estaminódios sepalóides centrais e 1 estaminódio externo. Além disso, no material seco a coloração do indumento das folhas é amarelada. Pera tomentosa também é próxima de $P$. decipiens e $P$. coccinea, espécies incluídas em Pera sect. Neopera e as características que as distinguem podem ser vistas na chave aqui fornecida.

\section{Pera sect. Pera Bigio \& Secco}

7. Pera anisotricha Müll. Arg., Fl. bras. 11(2): 426. 1874. Tipo: BRASIL. MINAS GERAIS. São João del Rey, 1818, Martius s/n (holótipo M; isótipo G; fotos $\mathrm{G}$ !).

Fig. 8

Spixia barbinervis Mart. ex K1., Arch. Naturgesch 7: 179. 1841, nom. nud.

Pera bahiana Ule, Bot. Jahrb. Syst. 42(2): 218. 1908. Tipo: BRASIL. BAHIA. Im gebüsch bei Maracás, 1000 m, IX.1906, fl., Ule 6964 (lectótipo B, designado por Silva Alves (1993); isolectótipos G, LE, K; fotos F!, G!, IAN!).

Pera barbinervis (Mart. ex K1.) Pax \& K. Hoffm. in Engler, Pflanzenr., IV, 147, XIII: 6. 1919, nom. nud.

Arbustos ou árvores dióicos, 2-20 m alt. $\times 7-22 \mathrm{~cm}$ diâm. Ramos pubescentes, tricomas estrelado-lepidotos. Folhas alternas, peninérveas, nervuras proeminentes na face abaxial, 5,0-16 cm compr. $\times 2,0-5,5$ larg., elípticas a elípticolanceoladas, coriáceas, margem inteira, base cuneada a arredondada, ápice acuminado ou raramente obtuso; face adaxial pubescente, tricomas estreladolepidotos, mais concentrados nas nervuras principal e secundárias; face abaxial pubescente, tricomas estrelado-lepidotos, distribuídos nas nervuras principal e secundárias, raramente encontrados também no restante do limbo, indumento barbado nas axilas das nervuras secundárias; glândulas ausentes; pecíolo 0,5-1,2 cm compr., levemente canaliculado, pubescente, tricomas estreladolepidotos. Inflorescências pseudantos axilares, fasciculados, unissexuadas, pubescentes, tricomas estrelado-lepidotos; pedúnculo $0,6-1 \mathrm{~mm}$ compr., denso pubescente, tricomas estrelado-lepidotos; bractéolas 2, 1-2 mm diâm., na base do invólucro, orbiculares, opostas, denso- pubescentes, tricomas estrelado-lepidotos; invólucro globoso, crasso, densopubescente, tricomas estrelado-lepidotos, o das flores estaminadas $0,7-1 \mathrm{~cm}$ diâm., os das flores pistiladas 1-1,5 cm diâm., ambos abrindo-se totalmente na antese. Flores estaminadas sésseis, cálice turbinado, 4-lobado, lobos 0,6-1 mm compr., concrescidos na base, ápices lacerados, esparso-seríceos, tricomas simples; estames 2-4 por flor, 1,5-2 mm compr., filetes 


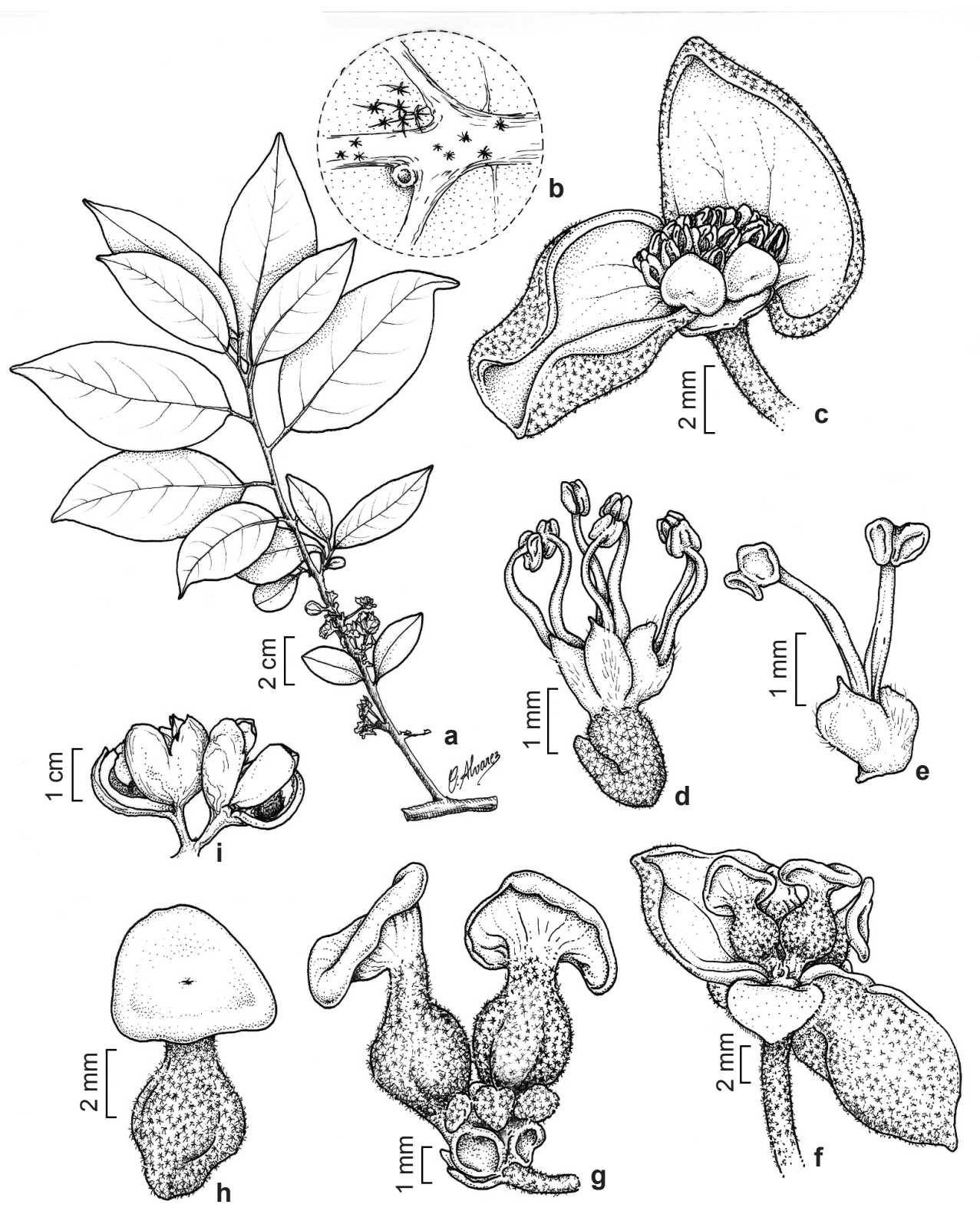

Figura 8-Pera anisotricha Müll. Arg. - a. ramo com inflorescências; b. detalhe da face abaxial da folha pubescente com tricomas estrelado-lepidotos na nervura principal e indumento barbado nas axilas; c. inflorescência estaminada com invólucro totalmente aberto na antese; $d$. três flores estaminadas: flores laterais com dois estames e flor central com três estames; e. flor estaminada com cálice seríceo, tricomas simples; f. invólucro da flor pistilada totalmente aberto na antese, com quatro flores, das quais duas estão em evidência; g. duas das quatro flores pistiladas, evidenciando os três estaminódios sepalóides na base; h. flor pistilada pubescente com tricomas estrelados, mostrando estigma umbraculiforme; i. dois frutos evidenciando cápsulas septífragas. (a-e M. Silva et al. 2509; f-h M. Silva et al. 2543; i U.N. Maciel et al. 224).

Figure 8 - Pera anisotricha Müll. Arg. - a. stem with inflorescences; b. leaf detail of pubescent lower surface with stellate-lepidote trichomes in the midrib and barbate in the axils; c. staminate inflorescence showing involucre completely opened at anthesis; d. three staminate flowers, flowers with two lateral stamens and central flower with three stamens; e. staminate flower showing the sericeous calyx with simple trichomes; f. pistillate inflorescene showing involucre completely opened at anthesis, with four flowers, two of which are in evidence; g. two pistillate flowers, showing the three sepaloid staminodia at the base; h. pistillate flowers pubscent with stellate trichomes, showing stigma umbraculate; i. two fruits. (a-e M. Silva et al. 2509; f-h M. Silva et al. 2543; i U.N. Maciel et al. 224). 
concrescidos até metade do comprimento, glabros, anteras $0,5-0,7 \mathrm{~mm}$ compr., pistilódio desenvolvido (rudimento de flor pistilada), lageniforme, 0,7-1,2 mm compr., pubescente, tricomas estrelados, estigma indiviso, umbraculiforme. Flores pistiladas subsésseis, pedicelo $0,3-1,0 \mathrm{~mm}$ compr., ovário $1,1-2,0 \mathrm{~mm}$ diâm., lageniforme, pubescente, tricomas estreladolepidotos, estilete $0,4-1,0 \mathrm{~mm}$ compr., estigma indiviso, umbraculiforme, face abaxial glabra, adaxial glabra não papilosa, estaminódios sepalóides, 2, centrais, 0,6-1 mm compr., cuneiformes, estaminódio filiforme 1, 1,7-2 mm compr. Fruto 1,2-1,7 cm compr. $\times 1,1-1,5 \mathrm{~cm}$ larg., subgloboso, rugoso, esparso-pubescente, tricomas estrelados, pedúnculo $0,5-1 \mathrm{~cm}$ compr. Sementes $7-8 \mathrm{~mm}$ compr. $\times 4-5 \mathrm{~mm}$ larg., ovóides, base cuneada, ápice obtuso, carúncula alaranjada, recobrindo $2 / 3$ da semente.

Material selecionado: ACRE: Brasiléia, Seringal Porongaba, colocação São José. $10^{\circ} 51^{\prime} \mathrm{S} 68^{\circ} 48^{\prime} \mathrm{W}$, 28.V.1991, D.C. Daly et al. 6759 (INPA). PARÁ: Santarém, Igarapé Curupira, 5.IX.1969, fl. (đ̋), $M$. Silva et al. 2509 (MG); Santarém, margem da estrada Pindobal - Porto Novo, 9.XII.1978, fr., U.N. Maciel et al. 224 (MG); Santarém, estrada do Palhão, ramal do Caatatú, 10.IX.1969, fl. (ㅇ) e fr., M. Silva et al. 2543 (MG); Marajó, Pau d'árco-Marajoara, 4.VIII.1998, fl., J. Grogan, 121 (IAN, INPA). MATO GROSSO: Luciara, distrito de Porto Alegre, $11^{\circ} 10^{\prime}$ S 51 $40^{\circ}$ 'W, 16.X.1985, fr. J. Pirani 1267 (MG).

Distribuição geográfica: Brasil, nos estados do Acre, Pará, Goiás, Mato Grosso, Bahia, Minas Gerais e Espírito Santo.

Após uma análise acurada da literatura e da coleção original, verificou-se que Pera barbinervis foi baseada em Spixia barbinervis, nome este apenas citado por Klotzsch (1841), com base em material de herbário coletado e denominado por Martius com esse nome, que também não a descreveu. Sendo assim, Spixia barbinervis é considerada nomina nudum, logo Pax \& K. Hoffmann (1919) não poderiam ter feito uma combinação nova, com base naquele epíteto. Sendo assim, decidiu-se considerar Pera anisotricha Müll. Arg. como o nome válido, colocando Pera barbinervis (Mart. ex K1.) Pax \& K. Hoffm. como um sinônimo.

Pera anisotricha foi assim designada por apresentar indumento barbado nas axilas das nervuras secundárias com a nervura principal, na face abaxial da folha. Essa característica de fácil reconhecimento auxilia na identificação deste táxon, mesmo quando em fase vegetativa. Tal espécie é morfologicamente semelhante às outras espécies de Pera que apresentam invólucros completamente abertos na antese e pistilódio desenvolvido nas flores estaminadas, entre elas, P. heteranthera, P. membranacea e P. eiteniorum.

Pera anisotricha parece mais próxima de P. membranacea, por ambas apresentarem o indumento nas folhas semelhantes, mas podem ser distinguidas, pois $P$. anisotricha apresenta indumento barbado nas axilas da nervura principal da face abaxial; cálice das flores estaminadas com indumento esparso-seríceo; flores pistiladas com estaminódio e o estigma umbraculiforme.

Existem mais duas espécies que se assemelham a $P$. anisotricha, pela presença de indumento barbado nas folhas, e uma delas é $P$. barbellata Standl., que ocorre no México, Honduras e Belize, apresentando nas nervuras da face abaxial das folhas indumento curtamente barbado nas axilas e tricomas estreladolepidotos esparsos. Standley (1930) não descreveu as flores, somente o fruto de $P$. barbelata, sendo que Standley \& Steyermark (1946) fizeram referência às flores estaminadas, que parecem ser de uma inflorescência antes da antese, mas não mencionaram a presença ou ausência de pistilódios nessas flores, apenas informando que as flores pistiladas têm estigma umbraculiforme. É possível que $P$. barbellata seja um sinônimo de $P$. anisotricha, mas para fazer essa afirmação seria necessário analisar os tipos dessas duas espécies, pois de ambas só foram analisadas as fotos dos tipos. A outra espécie é Pera colombiana Cardiel, que é restrita a Colômbia e, segundo Cardiel (1991), separa-se de $P$. anisotricha pela ausência de pistilódio nas flores estaminadas e pela quantidade de flores nos invólucros pistilados (4). A quantidade de flores no material examinado de $P$. anisotricha não diferiu de P. colombiana. Essas duas espécies diferenciam-se também pela ausência de estaminódios nas flores pistiladas de $P$. colombiana.

Pera anisotricha está sendo pela primeira vez citada para a Amazônia, apresentando uma distribuição disjunta, sendo as populações encontradas, isoladamente, no Pará, Mato Grosso, Bahia e Espírito Santo. Ocorre em campo rupestre, floresta ombrófila aberta, na zona da mata, mata de terra firme, capoeira rala e floresta secundária.

8. Pera eiteniorum Bigio \& Secco, Novon 21: 171. 2011. Tipo: BRASIL, MATO GROSSO. Barra do Garça, $254 \mathrm{~km}$ along new rd. NNE of village of Xavantina, $6.6 \mathrm{~km}$ due S of Base Camp, 12 $2^{\circ} 1^{\prime} \mathrm{S}$, $51^{\circ} 45^{\prime}$ W, 31.VIII.1968, fl. (ㅇ) e fr., G. Eiten \& L.T. Eiten 8499 (holótipo, SP!).

Fig. 9

Arbustos a árvores dióicos, $1,5-10 \mathrm{~m}$ alt. $\times$ ca. $20 \mathrm{~cm}$ diâm. Ramos tomentosos, às vezes glabros, 
tricomas estrelado-lepidotos. Folhas alternas, peninérveas, nervuras proeminentes na face abaxial, 5,5-21 cm compr. × 1,5-9 cm larg., subcoriáceas, lanceoladas a elíptico-lanceoladas ou raramente elípticas, margem inteira, base cuneada, ápice agudo a acuminado; face adaxial pubescente, tricomas estrelados, mais concentrados nas nervuras principal e secundárias, esparsos no restante do limbo, ou glabro; face abaxial denso-tomentosa, tricomas estrelados, na nervura principal tricomas estreladolepidotos, esparsos; glândulas ausentes; pecíolo 0,3-1 cm compr., canaliculado, tomentoso, tricomas estrelados. Inflorescências pseudantos axilares, fasciculados, unissexuadas, denso tomentosas, tricomas estrelado-lepidotos; pedúnculo 2-4 mm compr., denso-tomentoso, tricomas estreladolepidotos; bractéolas 2, 0,5-1 mm diâm. na base do invólucro, orbiculares, opostas, denso-tomentosas, tricomas estrelado-lepidotos; invólucro globoso; crasso, denso tomentoso, tricomas estrelados, o das flores estaminadas 3-7 mm diâm., o das flores pistiladas 0,4-1 cm diâm., ambos abrindo-se totalmente na antese. Flores estaminadas pediceladas, pedicelo 0,3-0,6 $\mathrm{mm}$ compr., cálice turbinado, 5-lobado, lobos 0,5-0,6 mm compr., concrescidos na base, ápice lacerado, esparso-seríceo, tricomas simples ou raramente glabros; estames 3 por flor, 2-2,5 mm compr., filetes concrescidos até a metade do comprimento, glabros, anteras 2-3 mm compr., pistilódio desenvolvido (rudimento de flor pistilada), lageniforme, 3-4 mm compr., denso tomentoso, tricomas estrelados, estigma indiviso, triangular. Flores pistiladas subsésseis, pedicelo 0,2 mm compr., ovário 1-1,3 mm diâm., lageniforme, denso-tomentoso, tricomas estrelados, estilete 0,3-1 mm compr., estigma indiviso, triangular, face abaxial tomentosa, tricomas estrelados, adaxial glabra, papilosa, estaminódios sepalóides 3 , centrais, 0,3-0,5 mm compr., urceolados, esparso- seríceo, tricomas simples, estaminódio sepaloide ausente, estaminódio filiforme 1, 0,8-1 mm compr., denso-tomentoso, tricomas estrelados. Fruto 1-1,5 cm diâm., globoso, rugoso, tomentoso, tricomas estrelados, pedúnculo 3-5 mm compr. Sementes 6-7 mm compr. x 4-5 mm larg., ovóides, base cuneada, ápice arredondado, carúncula alaranjada, cobrindo $2 / 3$ da semente.

Material selecionado: MATO GROSSO: próximo ao Rio Suiazinho, a $290 \mathrm{~km}$ NNW de Nova Xavantina, 1250'S 5153'W, 4.IX.1972, fl. (ठ), J. A. Ratter et al. $R 2331$ (UB); Ribeirão Cascalheira, perto da junção da estrada para Querência com BR-158 $12^{\circ} 43^{\prime}$ S 51 $53 \mathrm{~W}$., 19.VIII.1998, fl. (中) e fr., J. A. Ratter et al. R8088 (UB,

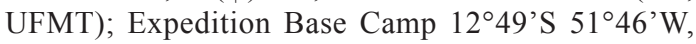

margem de estrada através da área de regeneração de cerrado, 5.XI.1968, fl. (ㅇ), R.M. Harley et al. 10940 (UB); Expedition Base Camp 1249'S 51 ${ }^{\circ} 46^{\prime} \mathrm{W}, 5 . X I .1968$, fl. (ठ)), R.M. Harley et al. 10941 (UB); Expedition Base Camp $5 \mathrm{~km}$ ao S., $12^{\circ} 54^{\prime} \mathrm{S} 51^{\circ} 52^{\prime} \mathrm{W}$, próximo da rodovia que liga Nova Xavantina à São Felix, 2.V.1968, fr., R.R. de Santos 1245 (UB); Expedition Base Camp 6km ao N., $12^{\circ} 54^{\prime} \mathrm{S} 51^{\circ} 52^{\prime} \mathrm{W}$, próximo a rodovia Nova Xavantina à São Felix, 25.IV.1968, fr., A. Ferreira et al. 1188 (UB); Ribeirão Cascalheira, cerca de $4,7 \mathrm{~km}$ a partir da BR158, 22.VIII.1997, fl. (), E.S. Lima et al. 149 (SP, UB); Sinop próximo à entrada para Vera, 07.XI.1995, fl. (ठ̋), M. Macedo et al. s/n (UFMT); Sinop próximo ao Rio Nandico, 30.V.1995, fr., M. Macedo et al. 4163 (UFMT); Rio Aripuanã, próximo ao centro Humboldt, descendo do Salto dos Dardanelos, 59²1'S 10¹2'W, 14.X.1973, fr., C.C. Berg et al. P18515 (MG, UFMT); Estação Ecológica Iquê-Juruena, 8.VIII.1981, fr., G. Guarim-Neto et al. 549 (UFMT); Estrada Xavantina-Cachimbo 5km W do km 264 da rodovia, 20.III.1968, fr., D. Philcox et al. 4591 (UB); Margem da BR- 80, Rod. Xavantina-Cachimbo. 10³3'S 534'' ' 18.X.1977, fr., B.C. dos Passos 1012 (RB,MG); Pontes de Lacerda 9km NW de Pontes e Lacerda na BR364 para Vilhena, $15^{\circ} 10^{\prime} \mathrm{S} 59^{\circ} 25^{\prime} \mathrm{W}, 31 . X .1985$, fl. (ठ̊), W. Thomas et al. 4735 (MG); Sinop 3-6km E of BR-163 on road N of Rio Celeste (MT 225), $12^{\circ} 18^{\prime} \mathrm{S} 55^{\circ} 34^{\prime} \mathrm{W}$, 17.IX.1985, fl., W.Thomas et al. 3842 (MG); Gaúcha do Norte, área urbana, $13^{\circ} 10^{\prime} \mathrm{S} 53^{\circ} 15^{\prime} \mathrm{W}, 13$.VIII.1999, fl. (ठ̋), N.M. Ivanuskas 4069 (SP); Dardanelos, Rio Aripuanã, estrada da Sta Helena, 17.VI.1974, fr., M.R. Cordeiro 129 (RB). PARÁ: Missão Cururu, 9.V.1977, fl. (ठ̋), N.A. Rosa et al. 1863 (MG, RB); Missão Cururu, woods sin sandy soil aboce the Lago dos Ciganos, E of the Missão, $7^{\circ} 35^{\prime}$ S $57^{\circ} 31^{\prime} \mathrm{W}, 6 . \mathrm{II} .1974$, fl. (ㅇ) e fr., W. R. Anderson 10565 (RB). RONDÔNIA: cerrado a $21 \mathrm{~km}$ de Presidente Médici, margem esquerda da BR 364, 27.III.1986, fl. (ð̋), N.A. Rosa et al. 4997 (MG); Vilhena, 13²43'S 59²0'W, 17.IV.77, fr., (RB 179045); Pimenta Bueno, margem do Rio Comemoração, 12²'47'’S 60³7'39'W, 26.VI.1998, fr., I. Miranda 2076 (MG).

Distribuição geográfica: no Brasil, estados do Pará, Rondônia e Mato Grosso.

Por apresentar o invólucro completamente aberto na antese, flores estaminadas com pistilódio desenvolvido, flores pistiladas com estigma indiviso, Pera eiteniorum deve ser colocada em Pera sect. Spixia. Nessa seção, P. eiteniorum está próxima de $P$. heteranthera (Schrank) I.M. Johnst., mas desta se afasta pela presença de tricomas estrelados na face abaxial da folha, cálice das flores estaminadas completamente glabros ou com tricomas simples, esparsos, estigma triangular e presença de estaminódio filiforme nas flores pistiladas. Dessa mesma seção, $P$. eiteniorum se aproxima de $P$. membranacea Leal, mas se diferencia desta por apresentar folhas subcoriáceas, glândulas pateliforme 


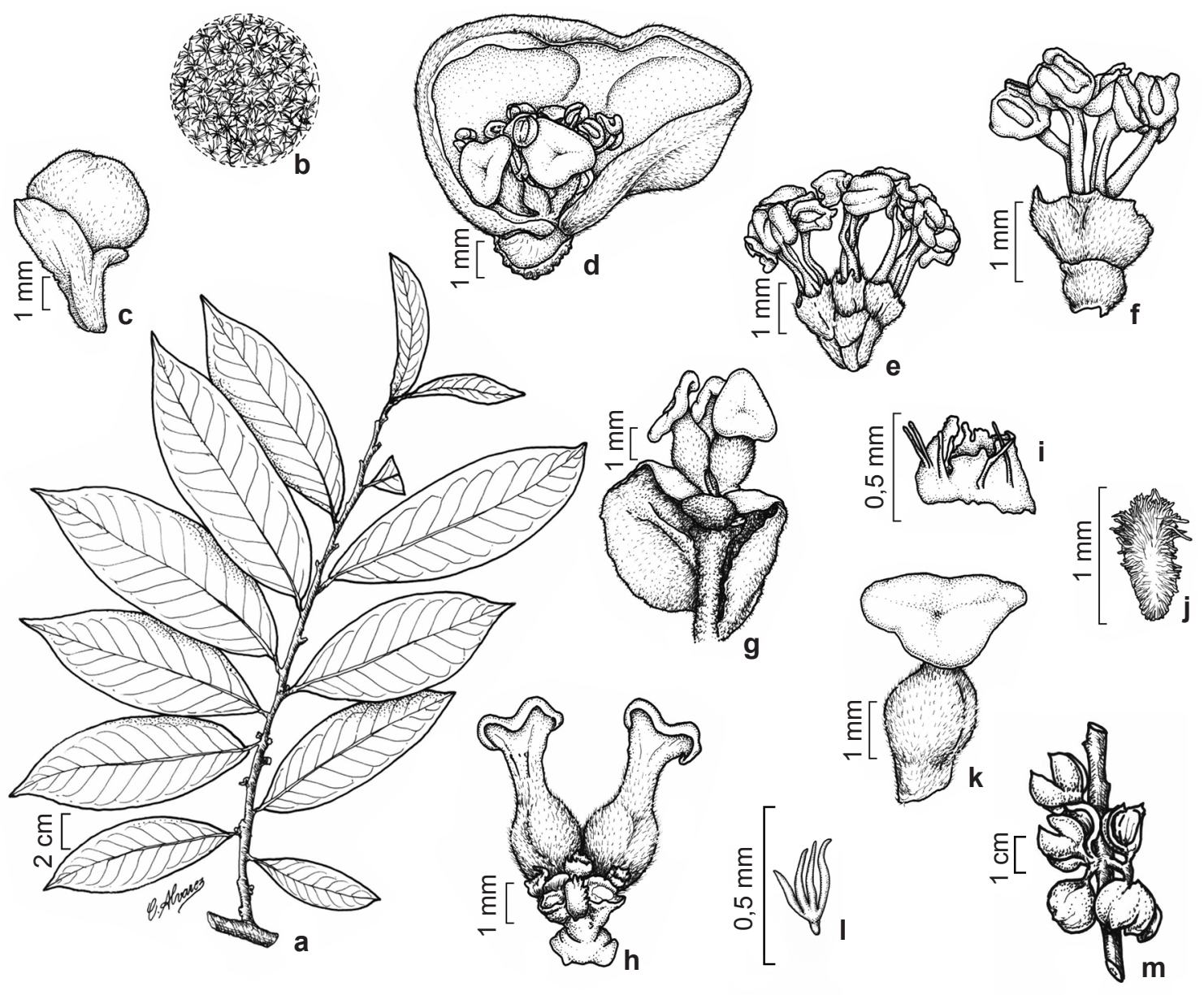

Figura 9 - Pera eiteniorum Bigio \& Secco - a. ramo com inflorescências estaminadas; b. detalhe da face abaxial denso tomentosa com tricomas estrelados; c. inflorescência imatura, mostrando as duas brácteas na base do invólucro; d. inflorescência estaminada mostrando o invólucro completamente aberto na antese com pistilódio desenvolvimento (rudimento de flor pistilada); e. três flores estaminadas com os pistilódios desenvolvidos (rudimento de flor pistilada) removidos; f. flor estaminadas com quatro estames, cálice turbinado esparso seríceo, tricomas simples; g. invólucro da inflorescência pistilada completamente aberto na antese; h. duas flores pistiladas, mostrando os três estaminódios sepalóides na base, e um estaminódio filiforme externo; i. detalhe do estaminódio sepalóide, com tricomas simples esparsos; j. detalhe do estaminódio filiforme, com denso indumento de tricomas estrelados (detalhe na Fig. 1L), com aparência de tricomas simples; $\mathrm{k}$. flor pistilada com denso indumento de tricomas estrelados no ovário (detalhe na Fig. 1L), com aparência de tricomas simples; 1. detalhe do tricoma estrelado encontrado no ovário e no pistilódio filiforme; m. detalhe do ramo com frutos. (a-c, e R.M. Harley \& R. Castro 10941; d, f M.N. Ivanuskas 4069; g J.A. Ratter et al. R8088; h-j E.S. Lima et al. 149; k-m G. Eiten \& L.T. Eiten 8499).

Figura 9-Pera eiteniorum Bigio \& Secco - a. stem with staminate inflorescences; $b$. leaf detail showing the dense indument of stellate trichomes; c. immature inflorescence, showing the two bracts present at the base of the involucre; $d$. staminate inflorescence showing involucre completely opened at anthesis with the developed, rudimentary pistillate flower; e. three staminate flowers with the developed, rudimentary pistillate flower removed; f. staminate flower with four stamens, showing the pedicel and the sparse, simple trichomes on the turbinate calyx; g. pistillate inflorescence showing the involucre completely opened at anthesis and three pistillate flowers; $h$. two pistillate flowers, showing the three basal sepaloid staminodia, and one filiform staminodium; i. detail of a sepaloid staminodium with sparse, simple trichomes; j. detail of a filiform staminodium, with dense indument of stellate trichomes (cf. trichome detail in Fig. 1L), resembling simple trichomes; k. pistillate flower with dense indument of stellate trichomes on the ovary (cf. trichome detail in Fig. 1L), resembling simple trichomes; 1 . detail of a stellate trichome as found on the ovary and on the filiform staminodium; $\mathrm{m}$. detail of the stem with several fruits. (a-c, e R.M. Harley \& R. Castro 10941; d, f M.N. Ivanuskas 4069; g J.A. Ratter et al. R8088; h-j E.S. Lima et al. 149; k-m G. Eiten \& L.T. Eiten 8499). 
ausentes na face abaxial da folha, indumento denso de tricomas estrelados na face abaxial, flores pistiladas com ovário lageniforme (em forma de garrafa, botija) e presença de estaminódio.

$\mathrm{O}$ indumento da folha de $P$. eiteniorum assemelha-se ao de $P$. tomentosa, que pertence a seção Pera sect. Neopera, porém diferencia-se desta por apresentar o invólucro completamente aberto na antese, inflorescência estaminada com pistilódio bem desenvolvido e flores pistiladas com estigma indiviso.

A distribuição de Pera eiteniorum parece estar concentrada em áreas de transição cerradoAmazônia, ocorrendo também em mata de terrafirme, mata de galeria e capoeira, localizadas em solo arenoso.

9. Pera heteranthera (Schrank) I.M. Johnst., Contr. Gray Herb. 68:90. 1923. Spixia heteranthera Schrank, Denksch. Köningl. Acad. Wissensch. München 7: 242. 1821. Tipo: BRASIL. RIO DE JANEIRO. 1819, Leandro 2 (holótipo M, foto $\mathrm{M}$ !).

Fig. 10

Spixia leandri Mart., Flora 24 (Beibl. 2): 30. 1841. Pera leandri (Mart.) Baill. Étude Gen. Euphorb. 434. 1858. Tipo: BRASIL. RIO DE JANEIRO. Corcovado, Martius 466 (lectótipo G, G-DC; fotos lectótipo G!, G-DC!), 467 (síntipos G, G-DC; fotos síntipo G!, IAN!).

Pera frutescens Leal, Arq. Jard. Bot. Rio de Janeiro 11: 66. 1951. Tipo: BRASIL. PARÁ. Rio Mojú, Fábrica. Arbusto grande, 3.XI.1923, fl. (ð̋), A. Ducke s/n (holótipo RB 18514!), syn. nov.

Pera alba Leal, Arq. Jard. Bot. Rio de Janeiro 11: 67. 1951. Tipo: Brasil, Rio de Janeiro, Reserva Florestal da "Fábria Aliança", Laranjeiras, 23.II.1922, fl. (ð)), J.G. Kuhlmann s/n (holótipo RB 20719!), syn. nov.

Árvores dióicas, 4-14 m alt. × 5-16 cm diâm. Ramos pubescentes, tricomas estrelados. Folhas alternas, peninérveas, nervuras proeminentes na face abaxial, 19,5-24 cm compr. × 7-9 cm larg., elípticolanceoladas a oblongo-lanceoladas, crassas, margem inteira, base arredondada a obtusa, ápice agudo a acuminado; face adaxial pubescente, tricomas estrelados, distribuídos apenas nas nervuras principal e secundárias; face abaxial denso-tomentosa, tricomas estrelado-porrectos; glândulas ausentes; pecíolo canaliculado a levemente canaliculado, 0,8-1,5 mm compr., pubescente, tricomas estrelados. Inflorescências pseudantos axilares, fasciculados, unissexuadas, tomentosos, tricomas estrelados; pedúnculo 2,5-3 mm compr., tomentoso, tricomas estrelados; bractéolas 2, 0,5-1 mm diâm., na base do invólucro, orbiculares, opostas, tomentosa, tricomas estrelados; invólucro globoso, crasso, tomentoso, tricomas estrelados, o das flores estaminadas 0,3-1 cm diâm., o das flores pistiladas $0,5-1 \mathrm{~cm}$ diâm., ambos abrindo-se totalmente na antese. Flores estaminadas pediceladas, pedicelo 0,4-0,6 $\mathrm{mm}$, cálice turbinado, 5-lobado, lobos 1-1,2 mm compr., concrescidos na base, ápices lacerados, ciliados, tricomas simples; estames 4 por flor, 1-2 mm compr., filetes concrescidos até a metade do comprimento, glabros, anteras 0,3-0,5 mm compr., pistilódio desenvolvido (rudimento de flor pistilada), obcônico, 1,8-2 mm compr., tomentoso, tricomas estrelados, estigma indiviso, umbraculiforme. Flores pistiladas pediceladas, pedicelo $0,3-0,5 \mathrm{~mm}$ compr., ovário 1-1,5 mm diâm., lageniforme, tomentoso, tricomas estrelados, estilete $0,7-1 \mathrm{~mm}$ compr., tomentoso, tricomas estrelados, estigma indiviso, umbraculiforme, face abaxial glabra, adaxial glabra, não papilosa, estaminódios sepaloides 3, centrais, 1-1,2 mm, oblongos, estaminódio filiforme ausente. Fruto 1-1,5 cm compr. $\times 1-1,5 \mathrm{~cm}$ larg., globoso, rugoso, pubescente, tricomas estrelados, pedúnculo ca. $0,4 \mathrm{~mm}$ compr. Sementes ca. $8 \mathrm{~mm}$ compr. $\times 4-5$ mm larg., obcônicas, base cuneada, ápice obtuso, carúncula alaranjada, recobrindo $1 / 3$ da semente.

Material selecionado: PARÁ: VII.1970, fl. (†), J.M. Pires et al. 12555 (IAN); Mojú, rio Mojú, 4.XI.1923, fl. (ठ)), A. Ducke s/n (RB 18514). BAHIA: Conde, Fazenda do Bu, margem da mata do Fundão I, $12^{\circ} 0$ '49' $S$ 3743'00”'W, 6.X.1995, fl. (ð), M. Clara et al. 795 (RB). RIO DE JANEIRO: Rio de Janeiro, estr. do redentor, 11.VIII.1959, fr., A.P. Duarte 4967 (RB).

Distribuição geográfica: Brasil, nos estados de Pará, Bahia, Minas Gerais, Rio de Janeiro, Espírito Santo e São Paulo.

Martius (1841) sinonimizou $S$. heteranthera, pois acreditou que o epíteto utilizado fosse errado e a publicou com novo nome: Spixia leandri. Johnston (1923), percebendo o equívoco de Martius (1841), utilizou o basiônimo Spixia heteranthera, deixando assim Pera leandri como sinônimo de Pera heteranthera.

Pera heteranthera apresenta uma característica peculiar, que é a presença de um pistilódio muito semelhante às flores femininas nas inflorescências estaminadas, e isso fez com que se acreditasse haver dois padrões de floração (Leandro Sacramento 1821), ou seja, com inflorescências tanto bissexuadas quanto unissexuadas.

A presença de pistilódios (rudimentos de flores pistiladas) bem desenvolvidos aproxima Pera heteranthera de três espécies que ocorrem na Amazônia: $P$. anisotricha, P. membranacea 

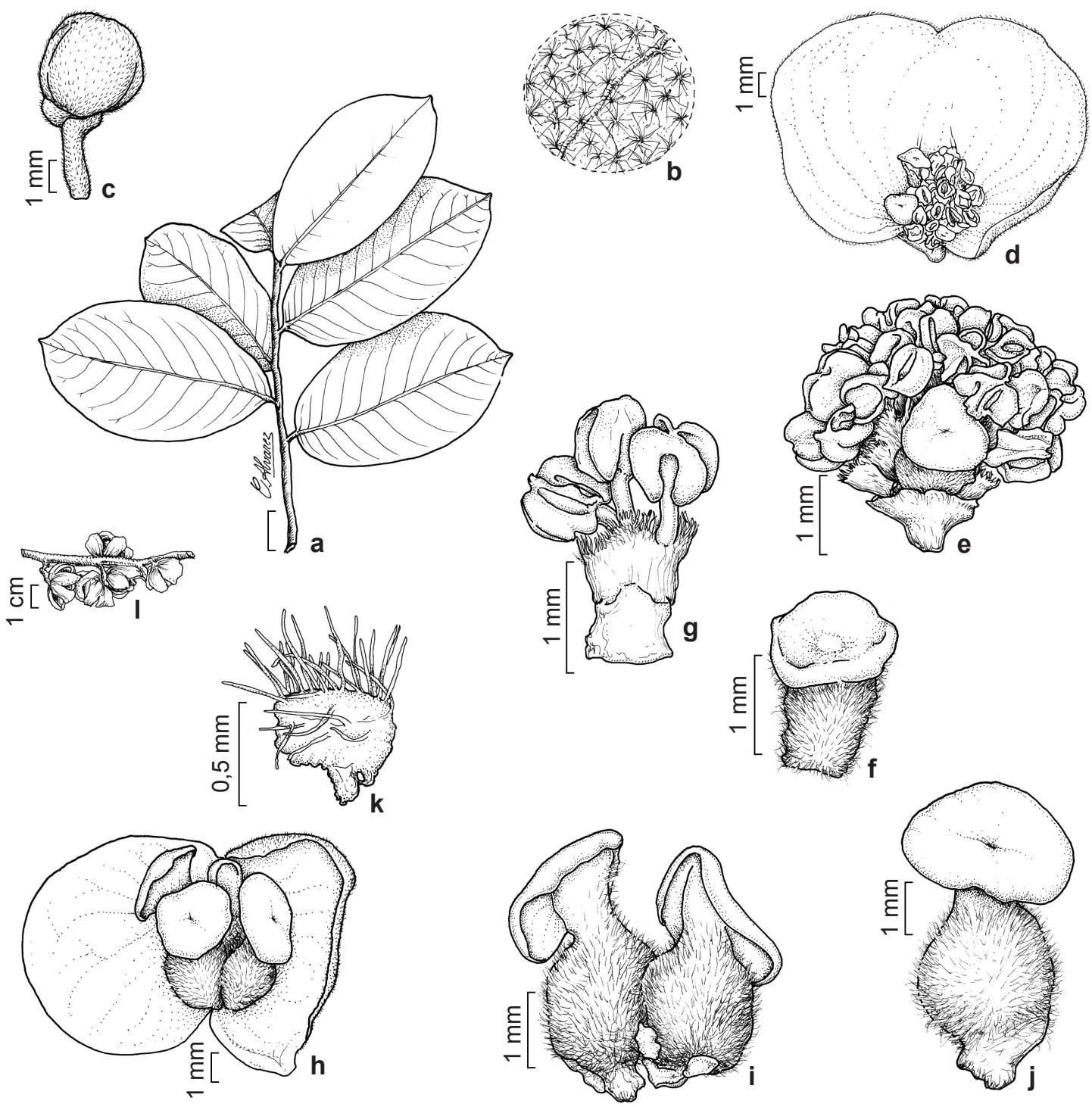

Figura 10 - Pera heteranthera (Schranck) I.M. Johnst. - a. ramo; b. detalhe da face abaxial da folha denso tomentosa; c. inflorescência imatura com duas brácteas opostas; d. inflorescência estaminada completamente aberta na antese; e. inflorescência estaminada com invólucro removido, mostrando três flores estaminadas e um dos quatros pistilódios; f. detalhe do pistilódio desenvolvido, com indumento tomentoso; g. detalhe da flor estaminada com três estames e cálice turbinado, com tricomas simples concentrados nas margens; h. inflorescência pistilada na antese, com invólucro completamente aberto; i. duas flores pistiladas com os estaminódios sepaloides na base; j. flor pistilada com estigma umbraculiforme e indumento tomentoso; $\mathrm{k}$. detalhe do estaminódio sepalóide com tricomas simples; 1. ramo com frutos (a-b, h-k J.M. Pires 12555; c-g M. Clara et al. 795; 1 A.P. Duarte 4967).

Figure 10 - Pera heteranthera (Schranck) I.M. Johnst. - a. stem; b. leaf detail of the dense tomentose lower surface; c. immature inflorescences with two opposite bracts; d. staminate inflorescence completely opened at anthesis; e. staminate inflorescence with involucre removed, showing three staminate flowers and one of the four pistilodia; f. developed pistilodium (rudimentary pistillate flower), tomentose; g. staminate flower with three stamens and turbinate calyx, with simple trichomes concentrated at the margins; h. pistillate inflorescence at anthesis, involucre completely opened; i. two pistillate flowers with sepaloid staminodia at the base; j. pistillate flower tomentose, with umbraculate stigma; k. sepaloids staminodia with simple trichomes; 1. stem with fruits. (a-b, h-k J.M. Pires 12555; c-g M. Clara et al. 795; 1 A.P. Duarte 4967). 
e $P$. eiteniorum. Na chave pode-se visualizar as características que diferenciam essas quatro espécies. Entre as características apresentadas, os tricomas na face abaxial e as inflorescências pistiladas é que mais auxiliam na distinção desses quatro táxons, todos membros de Pera sect. Pera e ocorrentes na Amazônia.

Após a análise do material identificado por Pax \& Hoffmann (1919), Müller (1874) e Webster, utilizaram as seguintes observações para separar Pera heteranthera de Pera frutescens: I. da foto do tipo (Martius 466) de Spixia leandri (=Pera heteranthera); II. do holótipo A. Ducke $s / n$ (RB 18514 !), e III. das características utilizadas por Leal (1951), tais como indumento, ápice acuminado da folha e número de nervuras. Entretanto, os autores aqui percebem que isto não as distingue satisfatoriamente, já que ambas apresentam tais características. Por isso resolveu-se pela sinonimização de $P$. frutescens como $P$. heteranthera.

Pera alba Leal também está sendo sinonimizada como $P$. heteranthera, pois quando foi descrita, Leal (1951) a considerou como espécie com uma única bractéola na base do invólucro. Porém, ao analisar-se o material-tipo de $P$. alba, observou-se duas bractéolas na base do invólucro e todas as demais características de indumento, inflorescência, entre outras, que correspondem àquelas de $P$. heteranthera.

Pera heteranthera tinha ocorrência relatada apenas para o Sudeste do Brasil (Minas Gerais, São Paulo, Espírito Santo e Rio de Janeiro) e estado da Bahia, no Nordeste. Aqui são apresentados dois espécimes provenientes do Pará, constituindo portanto novas ocorrências da espécie. Isto amplia sua área de distribuição geográfica, que é disjunta, com populações concentradas em determinadas localidades. De acordo com as etiquetas dos materiais examinados, essas populações podem ocorrer em restingas, mata costeira, floresta ombrófila aberta, campos gerais, caatinga, mata higrófila, campos naturais e cerrado.

10. Pera membranacea Leal, Arch. do Jard. Bot. do Rio de Janeiro 11: 67.1951. Tipo: BRASIL. PARÁ. Rio Tapajós, estrada das cachoeiras inferiores, Maria Luiza, capoeira, 24.XII.1919, fl. (q) e fr., A. Ducke s.n. (holótipo RB 10538!). Fig. 11

Árvores dióicas. Ramos pubescentes, tricomas estrelado-lepidotos. Folhas alternas, peninérveas, nervuras proeminentes na face abaxial, 4,5-20 cm compr $\times$ 4,5-7,5 cm larg., elíptico-oblongas a elíptico-lanceoladas, membranáceas, margem inteira, base cuneada a obtusa, ápice obtuso a levemente acuminado; face adaxial pubescente, tricomas estrelado-lepidotos, mais concentrados nas nervuras principal e secundárias, esparsos no restante do limbo; face abaxial pubescente, tricomas estrelado-lepidotos, mais concentrados nas nervuras principal e secundárias, mais esparsos no restante do limbo; glândulas pateliformes, na face abaxial ao lado da nervura principal; pecíolo 0,5-0,7 cm compr., canaliculado, pubescente, tricomas estrelado-lepidotos. Inflorescências pseudantos axilares, fasciculados, unissexuadas, pubescentes, tricomas estrelados-lepidotos; pedúnculo 0,7-1,5 mm compr., pubescente, tricomas estrelado-lepidotos; bractéolas 2, 0,5-1 $\mathrm{mm}$ diâm. na base do invólucro, orbiculares, opostas, pubescente, tricomas estrelado-lepidotos; invólucro globoso, crasso, pubescente, tricomas estrelado-lepidotos, o das flores estaminadas 7-9 $\mathrm{mm}$ diâm., o das flores pistiladas 0,5-1,0 cm compr., ambos abrindo-se totalmente na antese. Flores estaminadas sésseis, cálice turbinado, 4-5 lobado, lobos 0,8-1 mm compr., concrescidos na base, esparso-serício, ápice lacerado; estames 3-4 por flor, 3-4 mm compr., filetes concrescidos até a metade do comprimento, glabros, anteras $0,1-0,3$ mm compr., pistilódio desenvolvido (rudimento de flor pistilada), lageniforme, 2-3 mm compr., densoviloso, tricomas estrelado-tomentosos, estigma indiviso, triangular. Flores pistiladas subsésseis, pedicelo 1-1,2 mm compr., ovário 2-2,5 mm diâm., piriforme, denso-viloso, tricomas estrelados, estilete 1-1,5 mm compr., estigma indiviso, triangular, face abaxial vilosa, tricomas estrelados, adaxial glabra, papilosa, estaminódio ausente. Fruto ca. 1,5 diâm. x ca. 2 cm compr., subgloboso, rugoso, pubescente, tricomas estrelados, pedúnculo $0,5-1 \mathrm{~cm}$ compr. Sementes 5-6 mm compr. $\times 3-4 \mathrm{~mm}$ larg., ovóides, base cuneada, ápice obtuso a arredondado, carúncula alaranjada, cobrindo $1 / 3$ da semente.

Material selecionado: PARÁ: Rio Tapajós, estrada das cachoeiras inferiores, Maria Luiza, capoeira, 24.XII.1919, fl.() e fr., A. Ducke s.n. (RB 10538); Itaituba, estrada Santarém-Cuiabá, BR-163, km 1023, 13.V.1983, fr., M.N. Silva 312 (MG, RB); Serra dos Carajás, rio Itacaiúnas, 55'ㅇ 50³0’W, 12.V.1982, fl. (ठ̊), C.R. Sperling 6095 (MG); Parque Nacional do Tapajós, km 60 da estrada Itaituba - Jacareacanga, rio Tapajós, Vila Pimental, 25.XI.1978, fl. (đ̊), M.G. Silva et al. 3930 (MG). MARANHÃO: $15 \mathrm{~km}$ south of border Pará- Maranhão, Belém-Brasília, 31.VIII.1964, fl. (ठ̋), G.T. Prance et al. 58981 (UB).

Distribuição geográfica: Brasil, estado do Pará até a divisa com Maranhão. 

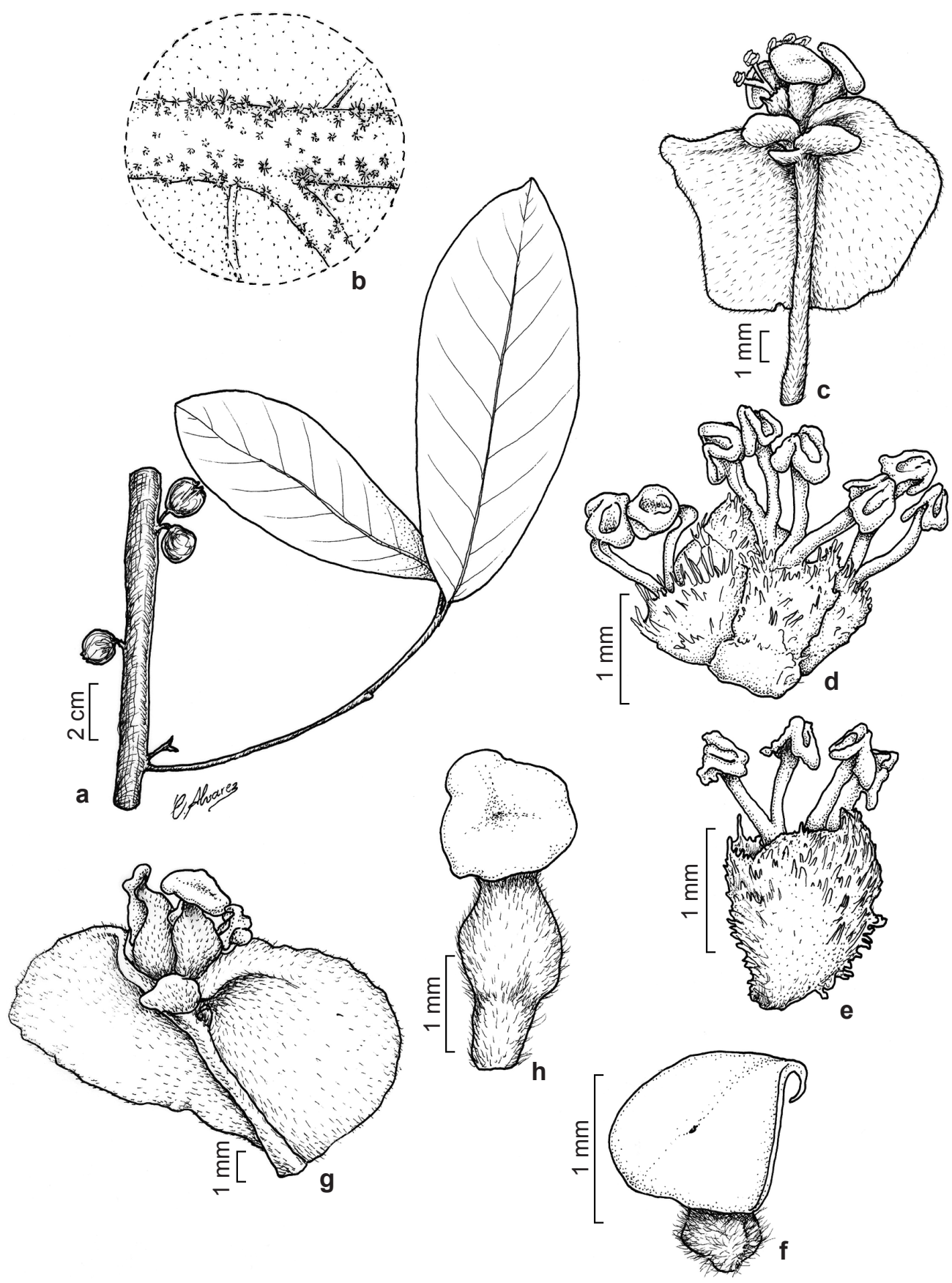

Figura 11 - Pera membranacea Leal. - a. ramo com frutos; b. detalhe da face abaxial da folha pubscente, com tricomas estrelado-lepidotos, concentrados especialmente na nervura principal; c. inflorescência estaminada com invólucro totalmente aberto na antese; d. três flores estaminadas, a flor central com quatro estames e as laterias com dois estames; e. flor estaminada mostrando o cálice esparso seríceo, com tricomas simples; f. pistilódio desenvolvido; g. inflorescência pistilada com invólucro completamente aberto na antese; $h$. flor pistilada denso viloso com tricomas estrelados. (a-b M.N. Silva 312; c-f M.G. Silva 3930; g-h A. Ducke RB 10538).

Figure 11 - Pera membranacea Leal. - a. stem with fruits; b. leaf detail of lower pubescent surface with lepidota trichomes, concentraded in the midrib; c. staminate inflorescence, involucre completely opened at anthesis; d. three staminate flowers, the central flower with four stamens and laterals with two stamens; e. staminate flower showing sparse sericeous turbinate calyx with simple trichomes; $\mathrm{f}$. developed pistilodium (rudimentary pistillate flower); g. pistillate inflorescence with involucre completely opened at anthesis; h. dense villous pistillate flowers with stellate trichomes. (a-b M.N. Silva 312; c-f M.G. Silva 3930; g-h A. Ducke RB 10538). 
Pera membranacea era conhecida somente pela coleção-tipo, que se apresentava com flores pistiladas e frutos. Com esse estudo foi possível descrever as flores estaminadas e conhecer outros locais de ocorrência da espécie, que parece ser restrita ao sul do Pará e ao limite entre o Pará e Maranhão.

A consistência da folha, membranácea, os tricomas estrelado-lepidotos na face abaxial desse órgão, a ausência de indumento barbado na axila da face abaxial, a presença de glândulas pateliformes ao lado da nervura principal na face abaxial da folha, a ausência de estaminódios nas flores pistiladas e o estigma triangular, possibilitam separar essa espécie de $P$. barbinervis, $P$. heteranthera e $P$. eiteniorum.

III. Pera sect. Peridium (Schott) Müll. Arg. 11. Pera benensis Rusby, Descr. S. Amer. Pl. 49. 1920. Tipo: BOLIVIA. Beni, junction of Rivers Beni and Madre de Dios, VIII.1886, fr. H.H. Rusby 2646 (holótipo NY; foto NY!). $\quad$ Fig. 12

Pera mildbraediana Mansf., Notizbl. Bot. Gart. Berlim 9: 265. 1925. Tipo: PERU. Middle Ucayali, Yarina Cocha, on highland, 4.XII.1923, fl., G. Tessmann 3406 (holótipo B; provavelmente destruído; fotos NY!).

Árvores dióicas, ca. $20 \mathrm{~m}$ alt. $\times 40 \mathrm{~cm}$ diâm. Ramos com tricomas lepidotos. Folhas opostas, peninérveas, nervuras proeminentes na face abaxial, 9-12 cm compr. $\times 4-6,5 \mathrm{~cm}$ larg., elíptico-oblongas, coriáceas, margem inteira, base cuneada a arredondada, ápice arredondado; face adaxial glabra, com pontuações; face abaxial denso lepidota, tricomas lepidoto-radiados; glândulas ausentes; pecíolo 2,5-3,5 cm compr., canaliculado, com tricomas lepidoto-radiados. Inflorescências pseudantos axilares, fasciculados, com tricomas lepidoto-radiados, pedúnculo 5-6 mm compr., com tricomas lepidoto-radiados; bractéolas 2, 0,5-1,0 $\mathrm{mm}$ diâm. na base do invólucro, orbiculares, opostas, denso-lepidotas, tricomas lepidoto-radiados; invólucro globoso, coriáceo, denso-lepidoto, tricomas lepidotos, o das flores estaminadas, 4-5 mm diâm., abrindo-se por uma fenda longitudinal na antese; inflorescências pistilada não analisada. Flores estaminadas sésseis, cálice reduzido, disforme, esparso-estrigoso, tricomas simples, estames 4-5 por flor, $1,2-1,8 \mathrm{~mm}$ compr., filetes concrescidos na base, glabros, anteras $0,5-1,0 \mathrm{~mm}$ compr., pistilódio ausente. Flores pistiladas não analisadas. Fruto ca. $0,6 \mathrm{~cm}$ diâm. $\times$ ca. $1 \mathrm{~cm}$ compr., ovóide, dilatado, glabro, pedúnculo $0,8-1 \mathrm{~cm}$ compr. Sementes ca. $5 \mathrm{~mm}$ compr. $\times$ ca. $3 \mathrm{~mm}$ larg., ovóides, carúncula avermelhada, cobrindo $1 / 2$ semente.
Material selecionado: AMAZONAS: Boca do Acre, floresta de várzea, $\mathrm{km}$ 1-5 da estrada Boca do Acre para rio Branco, 24.09.1966, fr., G. T. Prance et al. 2535 (MG). RONDÔNIA: rio São Miguel, mata da beria, campo circundando a Serra do Limoeiro, 20.VI.1952, fl. (đ), G.A. Black et al. 52-15216 (IAN).

Distribuição geográfica: Colômbia (Mansfeld 1925), Peru (Macbride 1951), Brasil (Amazonas, Rondônia) e Bolívia (Rusby 1920).

Usos: De acordo com Fournet et al. (1992), a casca do tronco de $P$. benensis é utilizada pelos índios Chimane, da Bolívia, para tratar leishmaniose cutânea, informando que seu uso é eficaz por apresentar naftoquinonas.

Por apresentar as folhas opostas, característica não muito comum nos represententes de Pera, $P$. benensis é próxima de $P$. pulchrifolia, distinguindose pelas seguintes características: folha menor, 9-12 cm compr. $\times 4-6,5 \mathrm{~cm}$ larg. enquanto $P$. pulchrifolia tem a folha maior, com $23-40 \mathrm{~cm}$ compr. $\times 10-14,5$ $\mathrm{cm}$ larg., tricomas lepidoto-radiados na face abaxial e face adaxial glabra; pecíolo maior em $P$. benensis (2,5-3,5 cm compr.), enquanto em $P$. pulchrifolia o pecíolo é menor (1-2 cm compr.), e ausência de cálice nas flores estaminadas de $P$. benensis. Devido à presença de tricomas lepidoto-radiados na face abaxial, $P$. benensis se aproxima de $P$. decipiens, mas desta se separa pela filotaxia e ausência de cálice nas flores estaminadas.

Outra espécie com folhas opostas que parece próxima de $P$. benensis é $P$. oppositifolia Müll. Arg., que apesar de apresentar distribuição geográfica restrita a Cuba, compartilha características em comum com $P$. benensis, tais como: face abaxial com denso indumento de tricomas lepidotos, ausência de cálice nas flores estaminadas e pecíolo longo. Estas características e também as fotos dos tipos sugerem que essas duas espécies sejam sinônimos e que se trate de apenas um táxon. Mas devido aos poucos matérias examinados, resolveuse ainda não considerá-las como sinônimos.

Macbride (1951), ao considerar $P$. mildbraediana como sinônimo de $P$. benensis, sugeriu que a presença de folhas opostas e quantidade de tricomas não é um fator determinante para esta espécie, sugerindo que $P$. benensis poderia ser uma variedade de P. glabrata. Provavelmente Macbride (1951) tenha se equivocado, já que a presença de folhas opostas parece ser um caráter diferencial e raro em Pera, sendo adequado para separar grupos de espécies. Além disso, P. benensis separa-se de . glabrata (ambas situadas em Pera sect. Peridium) por apresentar denso indumento 


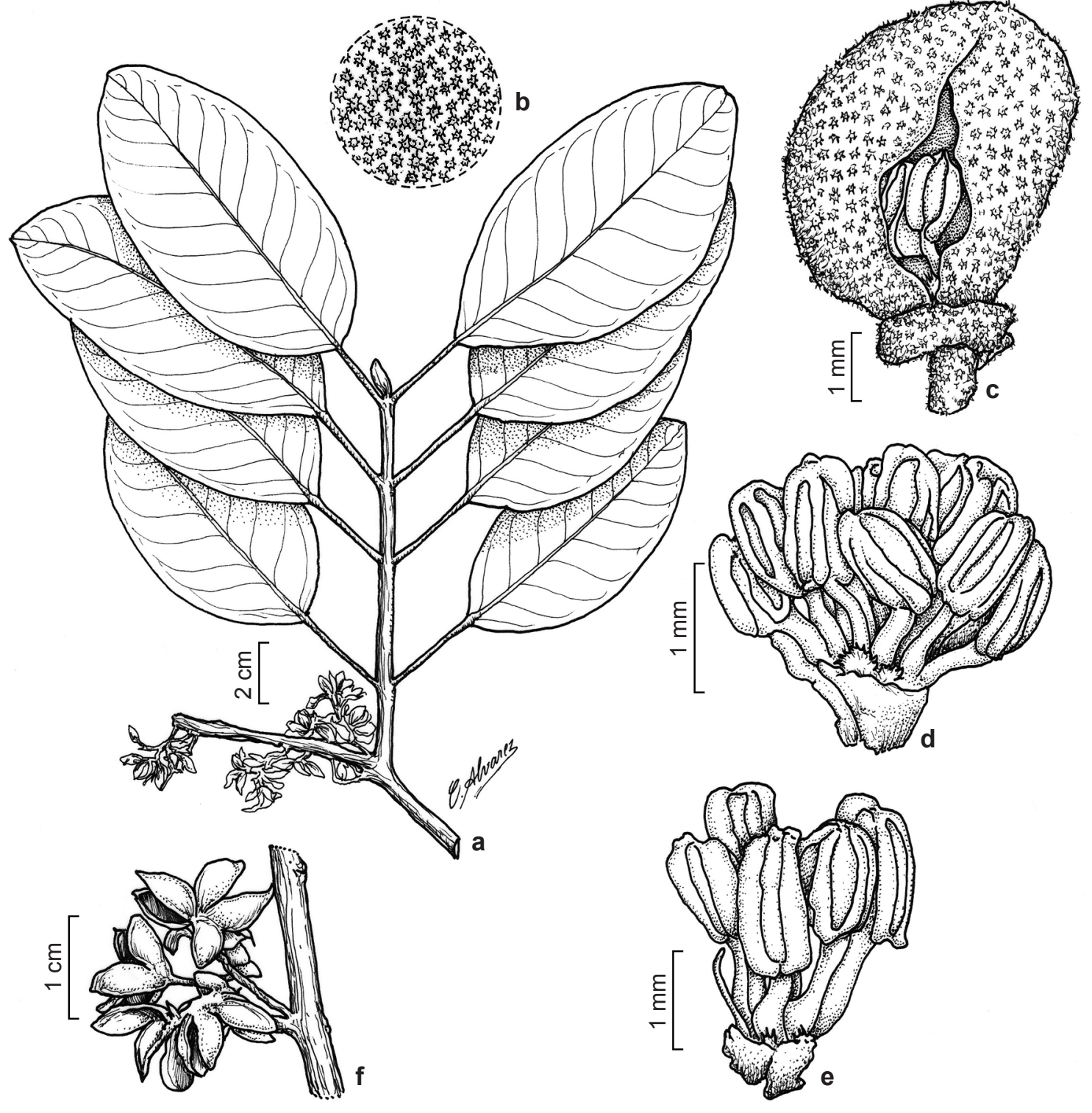

Figura 12 - Pera benensis Rusby. - a. ramo com frutos, mostrando as folhas opostas; b. detalhe da face abaxial denso lepidota com tricomas lepidoto-radiados; c. inflorescência estaminada abrindo-se por uma fenda longitudinal na antese; d. três flores estaminadas com invólucro removido; e. flor estaminada isolada com cálice disforme; f. frutos. (a-b, f G.T. Prance et al. 2535; c-e G.A. Black et al. 52-15216).

Figure 12 - Pera benensis Rusby. - a. stem with fruits, showing the opposite leaves; b. leaf detail of the dense lepidote lower surface with lepidote-radiated trichomes; c. staminate inflorescence opened by a longitudinal slit at anthesis; d. three staminate flowers with involucre removed; e. staminate flower with disform calyx; f. fruits. (a-b, f G.T. Prance et al. 2535; c-e G.A. Black et al. 52-15216). 
de tricomas lepidoto-radiados, em oposição ao tricoma lepidoto encontrado em $P$. glabrata; folhas com pecíolo maior em $P$. benensis $(2,5-3,5 \mathrm{~cm}$ compr.), em contraste com $P$. glabrtata $(0,4-0,9 \mathrm{~cm}$ compr.); ausência de glândulas pateliformes em $P$. benensis, ausência de sépalas e pistilódio nas flores estaminadas em $P$. benensis.

Pera benensis foi descrita, primeiramente, para a Bolívia (Rusby 1920) e depois foi encontrada no Peru (Macbride 1951). Para o Brasil, este é o primeiro registro, sendo que as flores pistiladas ainda são desconhecidas, já que o material analisado por Rusby (1920) e Macbride (1951) citavam frutos e os dois materiais analisados não apresentavam flores pistiladas.

12. Pera glabrata (Schott) Baill., Etud. Gen. Euphorb. 434. 1858. Peridium glabratum Schott, in Spreng., Syst. 4(2) (Cur. Post.): 410. 1827. Tipo: provavelmente BRASIL, Schott s/n (K 000601063; foto $\mathrm{K}$ !).

Fig. 13

Peridium obtusifolium Schott, in Spreng., Syst 4(2) (Cur. Post.): 410. 1827. Tipo: provavelmente BRASIL, Schott s/n (W0031198; foto W!).

Pera ferruginea (Schott) Müll. Arg., in DC. Prodr. 15(2): 1031. 1866. Peridium ferrugineum Schott, in Spreng. Syst 4(2) (Cur. Post.): 410. 1827. Tipo: BRASIL. Schott s/n (síntipos K000601068, K000601069; foto K!).

Peridium obovatum Klotzsch, Arch. Narturgesch. 7: 180. 1841, nom. nud.

Peridium ovale Klotzsch, Arch. Narturgesch.

7: 180. 1841, nom. nud.

Peridium parvifolium Klotzsch, Arch. Narturgesch. 7: 180. 1841, nom. nud.

Peridium oblongifolium Benth., Jour. Bot. \& Kew Misc. 2: 243. 1850. Tipo: BRASIL. PARÁ. Praia do rio Pará, perto de Caripi, Spruce 165 (K).

Pera klotzschiana Baill., Adansonia 5: 225. 1865. Tipo: Sellow s/n. (W?).

Pera obovata Baill., Adansonia 5: 225. 1865. Tipo: BRAZIL. s/dat., Sellow s.n (holótipo B; isótipos K, P; fotos K!, P!), s/dat.; BRASIL. SÃO PAULO. St. Hilaire cat. D, 708, 730 (P); BRASIL. SÃO PAULO. Gaudichaud 2, 129, 277 (P); BRASIL. SÃO PAULO. Guillemin 383 (P), syn. nov.

Pera bumeliifolia Baill. non Grisebach, Adansonia 5: 224. 1865. Tipo: BRASIL. MINAS GERAIS. A. St.-Hilaire 68, 78 (síntipos P; foto P!).

Pera bailloniana Müll. Arg., Prodr. 15(2): 1030. 1866. Tipo: BRASIL. MINAS GERAIS. A. St.-Hilaire 68 (holótipo P; foto P!). (nom. nov. para P. bumeliifolia Baill. non Grisebach), syn. nov.
Pera parvifolia Müll. Arg., Prodr. 15(2): 1031. 1866. Tipo: BRAZIL. Sellow s.n (isótipo B; fotos IAN!, NY), s/dat, syn. nov.

Pera glabrata var. parvifolia Glaz., Bull. Soc. Bot. France 59, Mem. 3g: 626. 1912. Tipo: BRASIL. Serra dos Órgãos a Teresópolis, Rio de Janeiro, Glaziou 8327 (holótipo P; foto P!).

Pera glabrata var. petroliana Glaz., Bull. Soc. Bot. France 59, Mem. 3g: 626. 1912. Tipo: BRASIL. Petrópolis au Retiro Rio de Janeiro, Glaziou 1116, 5985 (síntipo P; foto P!).

Pera glaziovii Taub. ex Pax, Pflanzer. IV.147. XIII: 12. 1919. Tipo: BRAZIL. RIO DE JANEIRO. Glaziou 7826 (isótipo BR, P; foto BR!, P!), s/dat, syn. nov.

Arbustos ou árvores dióicos, 3,5-35 m alt. $\times$ 15-60 cm diâm. Ramos com tricomas lepidotos. Folhas alternas, peninérveas, nervuras proeminentes na face abaxial, 6,2-10,9 cm compr. $\times 2,4-4,9 \mathrm{~cm}$ larg., elíptico-lanceoladas a lanceoladas, coriáceas a subcoriáceas, margem inteira, base cuneada, ápice obtuso, agudo a levemente acuminado; face adaxial glabra ou raramente com tricomas lepidotos na nervura principal; face abaxial esparso-lepidota, tricomas lepidotos, mais concentrados nas nervuras principal; glândulas pateliformes ao lado da nervura principal e das secundárias na face abaxial; pecíolo 0,4-0,9 cm compr., canaliculado, com tricomas lepidotos. Inflorescências pseudantos axilares, fasciculados, unissexuadas, com tricomas lepidotos; pedúnculos $0,3-1 \mathrm{~cm}$ compr., com tricomas lepidotos; bractéolas 2, 0,4-1 mm diâm., na base do invólucro, orbiculares, opostas a subopostas, com tricomas lepidotos; invólucro globoso, coriáceo, com tricomas lepidotos, o das flores estaminadas 4-4,3 mm diâm., o das flores pistiladas 4-6 mm diâm., ambos abrindo-se por uma fenda longitudinal na antese. Flores estaminadas sésseis, cálice reduzido, disforme, 0,2-1 mm de compr., esparso-seríceo, tricomas simples; estames 3-4 por flor, 1,5-1,8 $\mathrm{mm}$ compr., filetes concrescidos na base, glabros, anteras 1,2-1,5 mm compr., pistilódio desenvolvido (rudimento de flor pistilada) ausente, pistilódio filiforme 1, ca. 0,5 mm compr., com tricomas lepidoto-radiados. Flores pistiladas pediceladas, pedicelo 0,3-0,5 mm compr., ovário 0,5-1 mm diâm., globoso, glabro ou esparso a denso-lepidoto, tricomas lepidotos, estilete $0,1-0,3 \mathrm{~mm}$ compr., estigma trífido, lobos inteiros, 0,5-0,7 mm compr., face abaxial glabra ou esparso a denso-lepidota, tricomas lepidotos, a adaxial glabra, papilosa, estaminódio sepalóide 1, externo, 0,8-1 mm compr. 

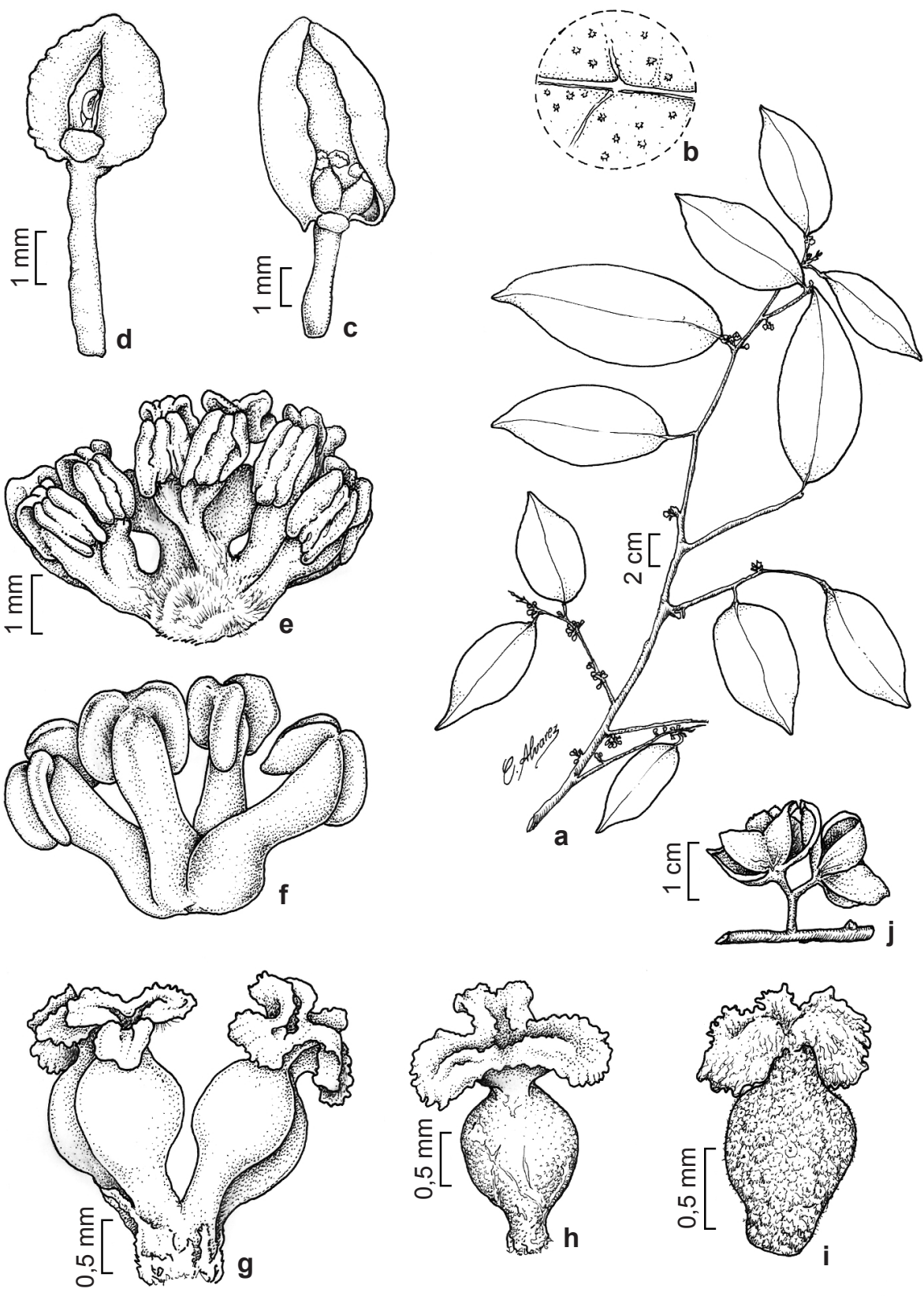

Figura 13 - Pera glabrata (Schott) Baill. - a. ramo com inflorescências estaminadas; b. detalhe da face abaxial da folha com tricomas lepidotos esparsos; c. inflorescência estaminada com invólucro abrindo-se através de uma fenda longitudinal na antese; d. inflorescência pistilada com invólucro abrindo-se através de uma fenda longitudinal na antese; e. três flores estaminadas mostrando cálice rudimentar com tricomas simples; f. detalhe da flor estaminada com quatro estames, sem o cálice rudimentar; g. flores pistiladas com estaminódio sepalóide; h. flor pistilada completamente glabra, evidenciando estigma trífido; i. flor pistilada denso lepidota; j. ramo com dois frutos maduros. (a-b $R$. Secco \& N.A. Rosa 881; c-f A. Ducke s/n (RB 18522); g-h N.A. Rosa et al. 1002; i-j M.G. Silva et al. 5358).

Figure 13 - Pera glabrata (Schott) Baill. - a. stem with staminate inflorescences; b. leaf detail of the lower surface with sparse lepidote trichomas; c. staminate inflorescence opening by a longitudinal slit at anthesis; d. pistillate inflorescence opening by a longitudinal slit at anthesis; e. three staminate flowers showing rudimentary calyx, simple trichomes; f. staminate flower with four stamens, without rudimentary calyx; g. pistillate flowers with sepaloid staminodia; h. completely glabrous pistillate flower showing 3-lobed stigma; i. pistillate flowers with dense lepidote trichomas; j. stem with two fruits. (a-b R. Secco \& N.A. Rosa 881; c-f A. Ducke s/n (RB 18522); g-h N.A. Rosa et al. 1002; i-j M.G. Silva et al. 5358). 
Fruto 1-2 cm diâm., globoso, rugoso, glabro ou esparso a denso-lepidoto, tricomas lepidotos, pedúnculo ca. $0,5 \mathrm{~cm}$ compr. Sementes ca. $5 \mathrm{~mm}$ compr., ovóides, base cuneada, ápice arredondado, carúncula avermelhada, cobrindo $2 / 3$ da semente.

Material selecionado: RORAIMA: Serra Tepequem, forest, 13.II.1967,, fl., G.T. Prance et al. 4368 (MG); Igarapé Agua Boa, rio Mucajaí, between Pratinha and rio Apiaú, 24.I.1967, fl., G.T. Prance 4070 (INPA). AMAZONAS: Reserva Ducke, 28.XII.1994, fl. (ð), J.E.L.S. Ribeiro et al. 1443 (IAN, RB); Reserva Ducke, Estrada para torre, 1.XI.1996, fr., C.A. Sothers et al. 742 (UB, IAN, INPA, MG, RB); G.NA -20-ZX. Ponto 9, Serra, 13.II.1975, fl., J.M. Pires 15097(177) (IAN); Manaus, Parque 10, 12.VII.1955, fl. (ð), Francisco s/n (MG 21887); Monte Dourado, rio Jarí, mata de terra firme, 10.XI.1968, fr., N.T. Silva 1362 (IAN); Humaitá, entre rio Livramento and Ipixuna, 7-18.XI.1934, fr., B.A. Krukoff 7121 (RB); Manaus, igarapé de Santa Maria, 19.III.1956, fr., $D$. Coelho $s / n$ (INPA 3628). AMAPÁ: rio Araguari, Porto Platon, 18.IX.1961, fl., J.M. Pires et al. 51039 (IAN); Macapá, rio Araguari, Porto Grande, 13.X.1976,

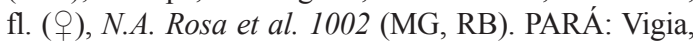
Ilha de Colares, capoeira, 29.XII.1953, fl., R.L. Fróes 30687 (IAN); Marajó, Ponte de Pedras, Ilha do Pindobal, próx. Fazenda São Marçal, 30.XI.1969, fr., B.S. Pena 174 (IAN); Belém, Bosque Rodrigues Alves, terra firme, 30.IX.1999, fl., M.R. Cordeiro 4642 (IAN); Concórdia do Pará, Carfanaum, $2^{\circ} 00^{\prime}$ S 475'W, 4.XI.2001, fl., M.R. Cordeiro MC-07-04(100.314) (IAN); Tucuruí, estrada para Repartimento, km 25, capoeira, 4.VI.1980 (fl. 9 e fr.), M.G. Silva et al. 5358 (IAN, INPA, MG); Bacarena, Caripi, 1'29'18'S 4842'01'”W, 13.III.2002, fl., A.S.L. da Silva et al. 3503 (MG); Maracanã, Centro de Treinamento do Idesp, 13.XII.1977, fl., E. Oliveira 6724 (MG); Collares, capoeirão, margem do rio, 19.VIII.1913, fl. (ㅇ), A. Ducke s/n (MG 12691); rio Tocantins, Tucuruí, Breu Branco, 10.V.1978, fl., M.G. Silva et al. 3483 (INPA, MG); Collares, campina, 17.VIII.1913, fl. ()), A. Ducke 12597 (MG, RB); Bragança, 9.II.1892, fl. (ठ̊), A. Ducke $s / n$ (RB 18522). MARANHÃO: Imperatriz, campo cerrado, 8.VIII.1949, fl., J.M. Pires et al. 1761 (IAN); São Luís, Reserva da CAEMA, 28.04.1998, fl., R.S. Secco \& N.A. Rosa 881 (IAN, MG). MATO GROSSO: Cocalinho, Fazenda Volpec, rio Forquilha $12^{\circ} 55^{\prime} 50.2^{\prime}$ 'S $53^{\circ} 45^{\prime} \mathrm{W}$, 1.VII.2000, fl., B.S. Marimon et al. 548 (SP); Mato Grosso do Sul: Bataguaçu, margem do Rio Pardo, 15.X.1991, fr., L.R.H. Bicudo et al. 183 (CGMS).

Material adicional examinado: SURINAME, Kaboerie: 20.X.1920, fl., D.L. Holland s/n (RB 27206).

Distribuição geográfica: Trinidad e Tobago, Guiana, Suriname, Guiana Francesa, Peru, Venezuela. No Brasil, nos estados de Amapá, Amazonas, Pará, Maranhão, Pernambuco, Bahia, Rondônia, Mato Grosso, Goiás, Minas Gerais, Espírito Santo, Rio de Janeiro, São Paulo, Santa Catarina, Rio Grande do Sul e Distrito Federal.
Usos: Lorenzi (1992) cita o uso do lenho dessa espécie obras de entalhe, lápis e caixotaria, sendo que poderia ser utilizada na arborização urbana, pois apresenta uma copa globosa, copiosa.

Müller (1866) propôs Peridium oblongifolium, P. klotzschiana, P. ovale, P. obtusifolium e Pera arborea Baill. como sinônimos de Pera glabrata e manteve Pera ferruginea como um outro táxon. Jablonski (1967) considerou $P$. ferruginea como sinônimo de $P$. glabrata, porque o que diferenciava essas duas espécies era a quantidade de tricomas no ovário, sendo que $P$. glabrata teria ovário completamente glabro e em $P$. ferruginea este órgão seria recoberto por tricomas lepidotos. O estudo de Pena (1989) confirmou, a partir de análise morfológica e anatômica, que esses dois nomes são sinônimos, posicionamento este que é aceito no presente estudo.

Na Amazônia, é possível encontrar coleções de Pera glabrata com ovário glabro ou densamente piloso, coberto por tricomas lepidotos, mas não se percebem outras diferenças nem nos órgãos vegetativos nem nos reprodutivos desses espécimes. O que ocorre em alguns espécimes herborizados é a presença de folhas maiores ou com a coloração mais opaca. No entanto, os demais caracteres confirmam tratar-se de $P$. glabrata.

Ao analisar amostras dos herbários CEN, IAN, MG, SP, RB e UB verificou-se que as plantas identificadas como P. obovata (Klotzsch) Baill. e P. parvifolia (Klotzsch) Müll. Arg., ocorrentes no Centro-Oeste, Sudeste e Sul do Brasil, apresentam características morfológicas muito semelhantes às de . glabrata, o que contribuiu para a sinonimização desses dois nomes em $P$. glabrata. Além disso, Pera parvifolia assemelha-se muito com $P$. glabrata var. petroliana e $P$. glabrata var. parvifolia, que foram sinonimizadas por Pax \& Hoffmann (1919), e isto reforça ainda mais que $P$. parvifolia seja sinônimo de P. glabrata.

Duas outras espécies pertencentes à Pera sect. Peridium (sensu Pax \& Hoffmann 1919), já foram consideradas como sinônimos de $P$. glabrata, e são elas: P. bailloniana e P. glaziovii. Apesar de no presente trabalho não terem sido analisadas amostras desses táxons, as descrições de ambos não apontam diferenças significativas que justifique tratá-los separadamente de $P$. glabrata. Por esse motivo, foram tratados aqui também como sinônimos de $P$. glabrata.

Com relação às espécies amazônicas, a mais próxima de $P$. glabrata é $P$. coccinea, mas que pode ser diferenciada de $P$. glabrata por essa apresentar tricomas lepidotos nas folhas, pela ausência de 
estaminódios sepalóides internos nas flores pistiladas e pela ausência de sépalas nas flores estaminadas. As duas são colocadas em seções diferentes, ou seja, enquanto $P$. glabrata está posicionada em Pera sect. Peridium, P. coccinea foi posicionada em Pera sect. Neopera. Nos espécimes de P. glabrata provenientes da Região Sudeste do Brasil, o cálice das flores estaminadas apresenta sépalas lanceoladas, enquanto nos do Norte do país o cálice é disforme, todo lacerado, com tricomas simples, esparsos.

Pera glabrata parece ser a espécie mais amplamente distribuída do gênero e ocorre, principalmente, na região Sudeste do Brasil, sendo que na Amazônia está restrita à determinadas localidades e por isso tem um padrão de distribuição disjunta. Lorenzi (1992) comentou que P. glabrata é uma espécie pioneira e provavelmente esta característica explique sua ampla distribuição, ocorrendo desde Trinidad e Tobago até o Rio Grande do Sul. No Brasil, é bastante conhecida nos ecossistemas de restinga e cerrado. Na Amazônia ocorre em locais com solo arenoso. Este é o primeiro registro da espécie em Mato Grosso do Sul.

IV. Pera sect. Schismatopera (Klotzsch) Baill. 13. Pera distichophylla (Mart.) Baill., Etud. Gen. Euphorb. 434. 1858. Schismatopera distichophylla (Mart.) Klotzsch, Lond. Jour. Bot. 2: 43. 1843. Spixia distichophylla Mart., Flora 24 (Beibl. 2): 30. 1841. Tipo: BRASIL. AMAZONAS. Manaus, ad flumen rio Negro, in arenosis prope Manaos, outubro, Martius 2786 (holótipo M). $\quad$ Fig. 14

Schismatopera martiana Klotzsch, Archiv für Naturgeschichte 7: 178. 1841. Tipo: Estampa A(Tafel VII, S. martiana Kl.) de Klotzsch (1841). Pela análise da foto do tipo (síntipo F; fotos F!, IAN!), observouse que refere-se à coleção Poeppig 2497 (Brasil. Ega, Amazonas 1832), não citada por Klotzsch (1841).

Schismatopera laurina Benth., Hook. J. Bot. \& Kew Misc. 6: 324. 1854, nom. nud.

Pera distichophylla var. genuina Müll. Arg., DC. Prodr. 15(2): 1026. 1866, nom. inval.

Pera distichophylla var. laurina (Benth.) Müll.Arg., DC. Prodr. 15(2): 1026. 1866. Tipo: BRASIL. Barra, rio Negro, 1850-1851, fl., Spruce 961 (tipo NY; foto NY!).

Pera distichophylla var. martiana Müll. Arg., DC. Prodr. 15(2): 1026. 1866. Tipo: BRASIL. Ega, Amazonas, 1832, fl., Poeppig 2497 (Tipo F; fotos F!, IAN!)

Pera distichophylla var. lanceolata Müll. Arg., Fl. bras. 11(2): 435. 1874. Tipo: BRASIL. CEARÁ, s/d, Gardner 918 (holótipo provav. BR).
Pera heterodoxa Müll. Arg., Fl. Bras. 11(2): 423. 1874. Tipo: BRAZIL. AMAZONAS. 10.1829, fl., Martius s.n (holótipo M; foto IAN!) (syn. fide Jablonski 1967).

Arbustos ou árvores monóicos, 2-10 m alt. × 8-20 cm diâm. Ramos seríceos ou, algumas vezes, glabros, tricomas simples ou, raramente, estrelados. Folhas alternas, peninérveas, nervuras proeminentes na face abaxial, 3,8-20,5 cm compr. $\times 1,8-7,5$ cm larg., elíptico-oblongas a elíptico-lanceoladas, coriáceas, subcoriáceas a membranáceas, margem inteira, base cuneada, obtusa ou arredonda, ápice agudo a levemente acuminado; face adaxial glabra ou raramente serícea, tricomas simples, distribuídos esparsamente na nervura principal; face abaxial esparso-serícea, raro glabra, tricomas simples, mais concentrados na nervura principal; glândulas pateliformes na região basal da face abaxial das folhas, ao lado da nervura principal; pecíolo 0,3-1 cm compr., raras vezes canaliculado, seríceo a raramente glabro, tricomas simples. Inflorescências pseudantos axilares, bissexuados, inseridos em uma espiga, 0,2-1,0 cm compr., ou raras vezes pseudantos fasciculados, seríceo-tomentosos, tricomas simples; pedúnculo 0,2-1,5 cm compr., seríceo-tomentoso, tricomas simples; bractéola 1, 1,3-2,2 mm diâm., na base do invólucro, orbicular, seríceo-tomentosa, tricomas simples; invólucro globoso, 0,3-1,5 mm diâm., crasso, seríceo-tomentoso externamente, tricomas simples, completamente aberto na antese. Flores estaminadas sésseis, cálice turbinado, íntegro, 0,5-2 mm compr., denso-seríceo externamente, tricomas simples, esparso-seríceo a glabro internamente, tricomas simples; estames 3-6 por flor, 3-5 mm compr., filetes conados, formando coluna estaminal, glabros ou esparsamente seríceos, tricomas simples, anteras 0,5-1 mm compr., pistilódio ausente. Flores pistiladas subsésseis, circundando as flores estaminadas, ovário 0,6-2 mm diâm., lageniforme, denso seríceo-tomentoso, tricomas simples, estilete 0,3-1,7 mm, denso-híspido, tricomas simples, estigma trífido, lobos inteiros 0,8-1,5 mm compr., face abaxial serícea, tricomas simples, adaxial glabra, papilosa, estaminódios ausentes. Fruto ca. $2 \mathrm{~cm}$ compr. $\times$ ca. $1 \mathrm{~cm}$ diâm., clavado, indumento seríceovelutino, tricomas simples, pedúnculo ca. $4 \mathrm{~mm}$ compr. Sementes 1,4-2,3 mm compr. $\times$ ca. $4 \mathrm{~mm}$, fusiformes, base cuneada, ápice agudo, carunculadas. Material selecionado: RORAIMA: estrada ManausCaracarí, km 355, 00'0’S 60³8'45'W, 18.XI.1977, fl., W.C. Steward et al. 98 (INPA); estrada Manaus/Caracaraí (BR-174), 05'S 6040’W, 14.VI.1985, fl., I. Cordeiro et al. 04 (INPA); São Luiz do Anauá, estrada ManausCaracaraí (BR 174), 00’N 6045’W, 21.VIII.1987, fl., 


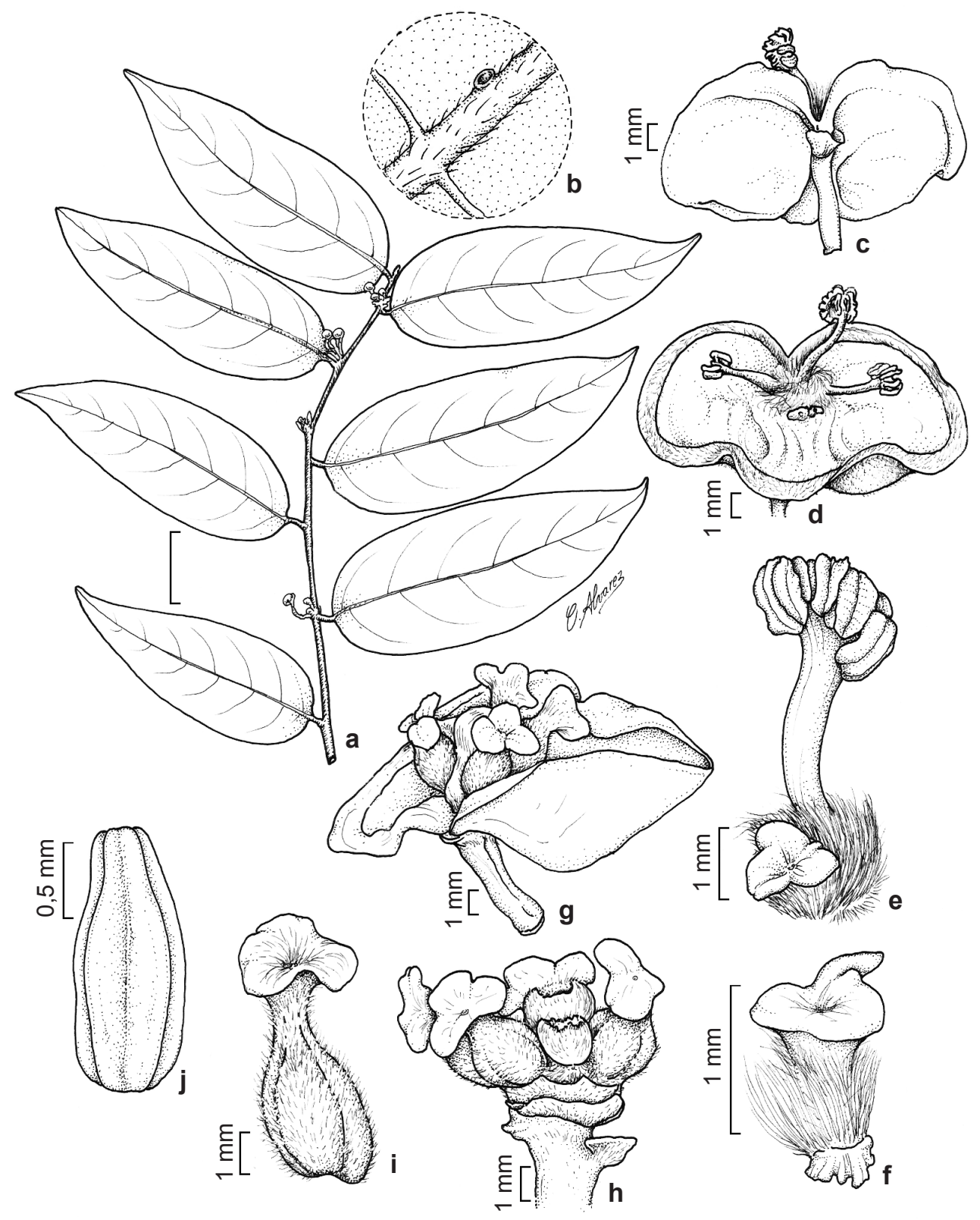

Figura 14 - Pera distichophylla (Mart.) Baill. - a. ramo com inflorescências; b. detalhe da face abaxial da folha, esparso-serícea na nervura principal; c. inflorescência evidenciando a única bráctea na base do invólucro; d. inflorescência com as flores estaminadas férteis; e. flor estaminada mostrando a coluna estaminal; cálice denso-seríceo na base e flor pistilada imatura; $f$. detalhe da flor pistilada imatura com indumento barbado; g. inflorescência com as flores pistiladas férteis; h. conjunto de quatro flores pistiladas, mostrando dois dos três cálices das flores estaminadas; i. flor pistilada com indumento denso híspido no ovário, evidenciando o estigma trífido; j. fruto clavado. (a-b D.G. Campbell et al. 22022; c-f L. Sonkin 220; g-h J: S.R. Hill et al. 12947; i A.P. Duarte 7095).

Figure 14 - Pera distichophylla (Mart.) Baill. - a. stem with inflorescences; b. leaf detail of sparse-sericeous lower surface on midrib; c. inflorescence showing the single bract at the base of the involucre; d. staminate inflorescences with fertile flowers; e. staminate flower showing the staminal column; sericeuos calyx and immature pistillate flower at the base; f. detail of immature pistillate flowers with barbate indumentum; g. pistillate inflorescences with fertile flowers; h. set of four pistillate flowers, showing two of the three calyx of staminate flowers; i. pistillate flowers with dense hispid indumentum on the ovary, showing the stigma trifid; j. fruit clavate. (a-b D.G. Campbell et al. 22022; c-f L. Sonkin 220; g-h J: S.R. Hill et al. 12947; i A.P. Duarte 7095). 
C.A. Cid Ferreira 9060 (INPA); AMAZONAS: Tefé, rio Tefé, 20.X.1975, fl., D.F. Coelho et al. s/n (INPA 53329); rio Negro, Ponto de Pagodão, Paraná de Anavilhanas, 2。45'S 6055'W, 9.VI.1990, fl., S. Mori et al.21257 (INPA); Ponta Negra, rio Negro, 16.II.1961, fl., W.A. Rodrigues et al. 2146 (INPA); Borba do rio Canumã, lugar Niterói, 2.IV.1960, fl., W. Rodrigues 1606 (INPA); Manaus, estrada BR 174, km 19, 6.X.1959, fl., W.A. Rodrigues et al. 1336 (INPA); Manaus, margem do Igarapé de água preta, s/data, fl., A.P. Duarte 7095 (RB, MG); Presidente Figueiredo, igarapé das lages, 17.IX.1997, fl., M.G.G. Vieira 1282 (INPA); rio Cuieras, $50 \mathrm{~km}$ upstream, farm of Sr. Nemerio, 2.IV.1974, fl., J.C. Ongley et al. P21802 (MG); rio Negro, margem esquerda, igapó do rio Branco, próximo ao "Paraná do Maçuera", 1²3'42"S, 6141'45”W, 6.VII.1999, fl., L. G. Lohmann 331 (INPA); Santa Isabel do rio Negro, Igarapé, 31.VII.1991, fl., G. Martinelli et al. 14621 (RB, MG); Itacoatiara, Seringal, km 21, mata alta terra firme, 7.XI.1963, fl., E. Oliveira 2879 (MG, IAN); Nova Olinda, rio Mari Mari, entre o rio Pará 1.VII.1989, fl., C. Todzia et al. 2289 (MG, UB); Maués, rio Maués-assu, $3^{\circ} 23^{\prime}$ S $57^{\circ} 45^{\prime} \mathrm{W}, 23$.VII.1983, fl., C.A. Cid 4233 (MG, RB); São Gabriel da Cachoeira, em direção a Camanaus, catinga, 07'S 6703'W, 13.XI.1987, fl., $W$. A. Rodrigues 10691(MG); São Miguel da Cachoeira, rio Negro, 8.III.1975, fl., J.M. Pires 15748 (IAN); Alvarães, igarapé Aruã, 28.XI.1982, fl., C.A.Cid et al. 3807 (MG, $\mathrm{RB})$; rio Solimões, igarapé Caiambé $3^{\circ} 33^{\prime} \mathrm{S} 64^{\circ} 24^{\prime} \mathrm{W}$, 20.X.1982, fl., C.A. Cid et al. 3329 (MG, RB); Ubavatá, rio Negro, 11.II.1959 (fl), J. S. Rodrigues 62 (IAN); rio Urubu, São Francisco, 24.VIII.1949, fl., R.L. Froés 24809 (IAN); rio Içana, Massarico, 21.X.1947, fl., J.M. Pires 691 (IAN); Uaupés, rodovia Perimetral Norte, 2.04.1975, fl., O.C. Nascimento et al. 37 (IAN); Muguentaua, rio Tefé, 15.VI.1950, fr., R.L. Froés 26279 (IAN); rio Negro, Eunixy, Matozinho, 18.V.1947, fl., R.L. Froés 22341 (IAN); rio Negro, rio Preto, Galoruca, 22.VI.1957, fl., R.L. Froés 33840 (IAN); rio Aracá, rio Negro, 29.X.1952, fl., R.L. Froés et al. 29146 (IAN); Parintins, Lago do Juruti, 18.I.1957, fl., R.L. Froés 33077 (IAN); rio Curuquetê, cachoeira Santo Antônio, 14.VII.1971, fl., G.T. Prance et al. 14186 (INPA, MG); Lábrea, igarapé Cuiatitú, 1.XI.1963, fl., G.T. Prance et al. 8165 (MG); Banks of rio Puciari tributary of rio Ituxi, 2.VII.1971, fl., G.T. Prance et al. 13784 (MG); rio Negro, arquipélago das Anavilhanas, 2.III.1976, fl., P. Cavalcante 3272 (MG); Urucara, São Sebastião, 6.IX.1968, fl., M. Silva 1855 (MG); rio Negro, rio Jauapari, Estirão do Lasca, 13.II.1977, fl., M.R. Santos 15 (MG); Baía de Buiaçu, lower rio Negro, 28.I.1971, fl., G.T. Prance et al. 11496 (MG); rio Negro, Tapuruquaramirim, rio Maril, 16.X.1978, fl., O.C. Nascimento 660 (MG); Maués dentro da plantação de Guaraná 20.IV.1974, fl., D.G. Campbell 22022 (UFMT). PARÁ: rio Mapuéra, Cachoeira do Tabuleiro e do Tabuleirinho, 17.11.1985, fl., L.S. Coelho et al. 171 (INPA); Santarém, Cachoeira do Aruã, Cantagalo, IX.1984, fl., L. Sonkin 220 (RB); rio Jamundá, Lago da Terra Santa, 17.I.1965, fl., M. Silva 1194 (MG, RB); Missão Cururu, elev. ca. 140m; 7³5'S 57³1'W, 6.II.1974, fl., W.R. Anderson 10501 (IAN); Boa
Esperança, cachoeira, Capoeira, 29.III.1951, fl., J.M.Pires 3645 (IAN); Lago Preto de Juruti, 18.I.1957, fl., E. Manoel de Oliveira 7 (IAN); Mojú, rio Moju, 1.VI.1954, fl., G.A. Black 54-16277 (IAN); rio Negro, Tanacoera, 26.IV.1911, fl., A. Ducke 11548 (MG); rio Trombetas, Oriximiná, 26.VIII.1968, fl., M. Silva 1772 (MG); Oriximiná 4²2’S 5840'W, Rio Abacaxis, 4.VII.1983, fl., S.R. Hill et al. 12947 (MG); Itaitala, 19.VIII.1902, fl., A. Ducke 2935 (MG); rio Jamundá, 14.VIII.1902, fl., A. Ducke 3734 (MG). RONDÔNIA: Vicinity of Mutumparaná, 1.VII.1968, fl., G.T. Prance et al. 5415 (INPA); Porto Velho, Granja do Palheta a $2 \mathrm{~km}$ de Guajará-Mirim, 3.V.1976, fl., O.C.Nascimento 283 (IAN); North bank of rio Abunã, $10 \mathrm{~km}$, above Fortaleza, 17.XI.1963, fl., G.T. Prance et al. 8539 (INPA, MG).

Material adicional examinado: COLOMBIA. GUAINIA: Maimachi, Serrania del Naquén, Maimachi, 29'S 68¹4'W, 11.III.1993, fl., S. Madriñan et al. 1004 (MG). VENEZUELA. AMAZONAS: Caño San Miguel between Limoncito and Caño Ikebenie, 29.VI.1959, fl. J.J. Wurdack 43255 (UB, MG).

Distribuição geográfica: Peru (Gillespie \& Armbruster 1997), Venezuela, Colômbia. No Brasil, nos estados Roraima, Rondônia, Amazonas, Pará e Ceará.

Jablonski (1967) sugeriu que $P$. heterodoxa fosse um sinônimo de $P$. distichophylla, porém não confirmou a sinonimização, deixando isso como uma dúvida. Baseando-se na descrição de Müller (1874), verificou-se que essas duas espécies diferenciam-se somente pela presença de inflorescências monoclinas em $P$. heterodoxa. A foto do tipo (depositada no IAN) também revelou que essas duas espécies são, morfologicamente, bastante semelhantes.

É realmente difícil saber se essas espécies são monóicas ou dióicas, pois os pistilódios das flores estaminadas são muito semelhantes a uma flor pistilada. Isso só poderia ser verificado com um estudo da biologia floral desta espécie. O que pode ocorrer é que as flores pistiladas, ao receberem pólen da mesma planta, abortem. Isso explicaria a dificuldade de se encontrar plantas com frutos. Em apenas um material foi encontrado um invólucro com flor pistilada desenvolvida conjuntamente com a flor estaminada. Pelo exposto, acredita-se que $P$. heterodoxa seja um sinônimo de $P$. distichophylla, e que essa espécie seja mesmo monóica.

Pera distichophylla deve ser mantida isoladamente na secção Schismatopera, por ser a única espécie com invólucro unibracteolado, estames soldados em uma coluna estaminal e fruto clavado. Isto a diferencia das demais espécies do gênero. Por apresentar o invólucro completamente aberto na antese e as flores estaminadas estarem 
envoltas por flores pistiladas, parece ser próxima das espécies de Pera sect. Spixia. Entretanto, na citada seção os táxons possuem invólucros com duas brácteas e os estames parcialmente unidos.

Pera distichophyllla apresenta distribuição mais concentrada no estado do Amazonas. A espécie ocorre em locais inundáveis (igapó), mata de terra firme, principalmente em regiões com solo arenoso, podendo ocorrer também em capoeiras ou matas preservadas. Tem distribuição disjunta, pois ocorre também no Ceará, conforme a coleção Gardner 918, citada por Müller (1874).

\section{Agradecimentos}

Ao CNPq, as bolsas de Mestrado e Produtividade em Pesquisa, concedidas ao autor e ao co-autor, respectivamente, para estudo das Euphorbiaceae da Amazônia; à Dra. Anna Luiza Ilkiu-Borges, chefe da CBO/MPEG, a leitura do manuscrito e sugestões; aos curadores dos herbários citados o empréstimo das coleções aqui analisadas e envio de fotografias; ao doutorando Alessandro Rosário o auxílio na formatação do texto; ao ilustrador Carlos Alvares as pranchas, e ao Dr. Hans-Joachim Esser, do Botanische Staatssammlung Muenchen, Munique, as sugestões feitas ao manuscrito durante a primeira avaliação do texto pela Coordenação de Editoração do Museu Paraense Emilio Goeldi.

\section{Referências}

Airy Shaw, H.K. In: Willis, J.C. 1973. A dictionary of the flowering plants and ferns. $8^{a}$ ed. Cambridge University Press, Cambridge. Pp. 871-872.

APG II. 2003. An update of the Angiosperm Phylogeny Group classification for the orders and families of flowering plants: APG II. Botanical Journal of the Linnean Society 141: 399-436.

APG III. 2009. An update of the Angiosperm Phylogeny Group classification for the orders and families of floweringplants: APG III. Botanical Journal of the Linnean Society 161: 105-121.

Baillon, H. 1858. Étude générale du groupe des Euphorbiacées. Masson, Paris. Pp. 433-435.

Baillon, H. 1865. Euphorbiacées Americaines. Adansonia 5: 223- 225.

Barroso, G.M.; Morim, M.P.; Peixoto, A.L. \& Ichaso, C.L.F. 1999. Frutos e sementes - morfologia aplicada à sistemática de dicotiledôneas. Universidade Federal de Viçosa, Viçosa. 443p.

Bentham, G. 1850. Report on the dried plants collected by Mr. Spruce in the neighbourhood of Pará in the months of july, august, and september, 1849. Hooker's Journal of Botany and Kew Garden Miscellany 2: 233-244.
Bentham, G. 1854. On the North Brazilian Euphorbiaceae in the collections of Mr. Spruce. Hooker's Journal of Botany and Kew Garden Miscellany 6: 321-377.

Bigio, N.C. \& Secco, R.S. 2010. Uma nova espécie de Pera (Peraceae) endêmica de Manaus, Amazonas, Brasil. Rodriguésia 61: 77-81.

Bigio, N.C. \& Secco, R.S. 2011. A new species of Pera (Euphorbiaceae) from Amazonia Brazil. Novon 21: 169-173.

Cardiel, J.M.S. 1991. Una nueva especie de Pera (Euphorbiaceae) de Colombia. Caldasia 16:311-316.

Croizat, L. 1942. Euphorbiaceae. In: Woodson, R.E. \& Schery, R.W. (eds.). Flora of Panamá VI. Annals of Missouri Botanical Garden 29: 353-357.

Ducke, A. 1937. New forest trees of the Brazilian Amazon, Euphorbiaceae. Tropical woods 50: 36-37.

Erdtman, G. 1952. Pollen morphology and plant taxonomy. Angiosperms. Almquist \& Wiksell, Stockholm. 538p.

Font Quer, P. 1953. Dicionario de botánica. Península, Barcelona. 1244p.

Fournet, A.; Angelo, A.; Munoz, V.; Roblot, F.; Hocquemil sler, R. \& Cave, A. 1992. Biological and chemical studies of Pera benensis, a Bolivian plant used in folk medicine as a treatment of cutaneous leishmaniosis. Journal of Ethnopharmacology 37: 159-164.

Francisco, M.R.; Lunardi, V.O. \& GalettI, M. 2007. Bird attributes, plant characteristics, and seed dispersal of Pera glabrata (Schott) Baill, (Euphorbiaceae) in a disturbed cerrado area. Brazilian Journal of Biology 67: 627-634.

Gilbert, M.G. 1994. The relationships of the Euphorbieae (Euphorbiaceae). Annals of Missouri Botanical Garden 81:283-288.

Gillespie, L.J. 1999. Pera. In: Webster, G.L.; Berry, P.E.; Levin, G.A.; Esser, H.J.; Gillespie, L.J.; Hayden, J.; Armbruster, W.S.; Secco, R.S. \& Heald, S. 1999. Euphorbiaceae. In: Steyermark, J.A.; Berry , P.E. \& Holst, B.K. (eds.). Flora of the Venezuela Guayana. Vol. 5, Euriocaulaceae-Lentibulariaceae. Missouri Botanical Gardens Press, St. Louis. Pp. 187-191

Gillespie, L.J. 1993. Euphorbiaceae of the Guianas. Annotated species checklist and key to the genera. Brittonia 45: 56-94.

Gillespie, L.J. \& Armbruster, W.S. 1997. A contribution to the Guianan flora: Dalechampia, Haematostemon, Omphalea, Pera, Plukenetia and Tragia (Euphorbiaceae) with notes on subfamily Acalyphoideae. Smithsonian Contributions to Botany 86: 1-48.

Glaziou, A.F.M. 1912. Liste des plantes du Brésil central recuilles. Bulletin de la Societé Botanique de France, v. 59. Memoirs 3g : 585-661.

Gordillo, M.M. \& Morrone, J.J. 2005. Patrones de Endemismo y disyunción de los Géneros de Euphorbiaceae sensu lato: una análisis panbiogeográfico. Boletín de la Sociedad Botánica de México 77: 21-33.

Govaerts, R.; Frodin, D.G. \& Radcliffe-Smith, A. 2000. World checklist of Euphorbiaceae (and Pandaceae) 
Euphorbiaceae: Pera. Vol. 4. Royal Botanic Gardens, Kew. Pp.1247-1252.

Grisebach, A. 1865. Diagnosen neuer Euphorbiaceen aus Cuba. Nachrichten von der Königliche Gesellschaft der Wissenschaften un der G.A. Universität zu Göttingen 7: 180-181.

Hayden, W.J. \& Hayden, S.M. 2000. Wood anatomy of Acalyphoideae (Euphorbiaceae). International Association of Wood Anatomists Journal 21: 213-235.

Hernandez Alba, G. 1957-1958. Diario de observaciones de José Celestino Mutis (1760-1790). 2 vols. Instituto Colombiano de Cultura Hispánica, Bogotá.

Hernandez Alba, G. 1893. Archivo epistolar del sábio José Celestiono Mutis. Ed. Presencia. Bogotá, v. 1.

Holmgren, P.K.; Holmgren, N.H. \& Barnett, N.H. 1990. Index herbariorum. Part I: the herbaria of the world. $8^{\circ}$ ed. New York Botanical Garden, New York, 693p.

Hutchinson, J. 1969. Tribalism in the family Euphorbiaceae. American Journal of Botany 56: 738-758.

Inamdar J.A. \& Gangadhara, M. 1977. Studies on the trichomes of some Euphorbiaceae. Feddes repertorium specierum novarum regni vegetabilis 88: 103-111.

Jablonski, E. 1967. Euphorbiaceae - Tribo Pereae. In: Maguire, B. (ed.). The Botany of the Guayana Highland, VI. Memoirs of The New York Botanical Garden 17: 147-151.

Johnston, I.M. 1923. Diagnoses and notes relating to the Spermatophytes chiefly of North America. Contributions from the Gray Herbarium of Harvard University 68: 90-91.

Klotzsch, J.F. 1841. Neue und weniger gekannte südamerikanische Euphorbiaceen - Gattungen. Archiv fur Naturgeschichte 7: 175-204.

Klotzsch, J.F. 1843. Euphorbiaceae. In: Bentham, G. XIV. Contributions towards a flora of South America, enumeration of plants "Collected by $\mathrm{Mr}$. Schomburgk, in British Guiana". London Journal of Botany 2: 42-52.

Klotzsch, J.F. 1859. Linne's natürliche Pflanzenklasse Tricoccae des Berliner Herbarium's im Allgemeinen und die natürlich Ordnung Euphorbiaceae insbesondere. Denkschriften der Königlichen Academie der Wissenschaften zu München. Pp. 236-254.

Lanjouw, J. 1931. The Euphorbiaceae of Surinam. 195f. Doctor's Thesis. Universiteit te Utrecht. Amsterdam.

Lanjouw, J. 1939. Euphorbiaceae-Pera. In: Pulle, A. (ed.). Flora of Suriname. Vol. 2. Koninklijke Vereeniging Koloniaal Instituut, Amsterdam. Pp. 61-64.

Leal, C.G. 1951. Contribuição ao estudo da família Euphorbiaceae. Archivos do Jardim Botânico do Rio de Janeiro 11: 63-71.

Lorenzi, H. 1992. Árvores brasileiras: manual de identificação e cultivo de plantas arbóreas e nativas do Brasil. Vol. 1. Plantarum, Nova Odessa. 109p.
Macbride, J.F. 1951. Flora of Peru, Euphorbiaceae. Botanical Series - Field Museum of Natural History 13(3A, n. 1): 106-108.

Mansfeld, R. 1925. Euphorbiaceae. In: Mildbraed, J. (ed.). Plantae Tessmannianae peruvianae II Notizblatt Botanischen Gartens Museums Berlin 9: 264-265.

Martius, C.F.P. 1841. Herbarium Florae Brasiliensis. Flora 24 (Beibl. 2): 30-31.

Müller, J. 1865. Euphorbiaceae, Tribo VII: Acalypheae, Subtribo XIII. Pereae. Linnaea 34: 200-201.

Müller, J. 1866. Euphorbiaceae, Tribo III: Acalypheae, Subtribo XIII. Pereae. In: De Candolle, A.P. (ed.). Prodromus systematis naturalis regni vegetabilis. Masson, Paris. 15(2), p. 1025-1031.

Müller, J. 1874. Euphorbiaceae, Tribo III: Acalypheae, Subtribo X Pereae. In: Martius, C.F.P. \& Eichler, A.G. (eds.). Flora brasiliensis. Masson \& Filii, Paris. V. 11(2), p. 422-432.

Mutis, J.C. 1784. Pera arborea, et nytt Orte-flagte ifran America. Kongliga Svenska Vetenskaps Academien 5: 299-301.

Nelson, B.W.; Ferreira, C.A.C.; da Silva, M.F.; Kawasaki, M.L. 1990. Endemism centers, refugia and botanical collection in Brazilian Amazonia. Nature 845: 714-716.

Nowicke, J.W.; Takahashi, M. \& Webster, G.L. 1998. Pollen morpholgy, exine structure and systematics of Acalyphoideae (Euphorbiaceae) Part. 1 Tribes Clutieae (Clutia), Pogonophoreae (Pogonophora), Chaetocarpeae (Chaetocarpus, Trigonopleura), Pereae (Pera), Cheiloseae (Cheilosa, Neoscortecchinia), Erismantheae pro parte (Erismanthus, Moultonianthus), Dicoelieae (Dicoelia), Galearieae (Galearia, Microdesmis, Panda) and Ampereae (Amperea, Monotaxis). Review of Paleobotany and Palynology 102: 115-152.

Nowicke, J.W. \& Takahashi, M. 2002. Pollen morphology, exine structure and systematics of Acalyphoideae (Euphorbiaceae), Part 41 Tribes Acalypheae pro parte (Erythrococca, Claoxylon, Claoxylopsis, Mareya, Mareyopsis, Discoclaoxylon, Micrococca, Amyrea, Lobanilia, Mallotus, Deuteromallotus, Cordemoya, Cococceras, Trewia, Neotrewia, Rockinghamia, Octospermum, Acalypha, Lasiococca, Spathiostemon, Homonoia), Plukenetieae (Haematostemon, Astrococcus, Angostyles, Romanoa, Eleutherostigma, Plukenetia, Vigia, Cnesmone, Megistostigma, Sphaerostylis, Tragiella, Platygyna, Tragia, Acidoton, Pachystylidium, Dalechampia), Omphaleae (Omphalea), and discussion and summary of the complete subfamily. Review of Paleobotany and Palynology 121: 231-336.

Pax, F.A. \& Hoffmann, K. 1919. Euphorbiaceae-Pereae. In: Engler, A. (ed.). Das Pflanzenreich. Leipzig: Engelmann, IV.147.XIII: 1-14. 
Pax, F.A. \& Hoffmann, K. 1931. Euphorbiaceae. In: Engler, A. \& Prantl, K. (eds.). Die Naturlichen Pflanzenfamilien. Engelmann, Leipzig. 19c, p.11-233.

Pena, E.L. 1989. Estudo taxionômico e morfológico de Pera glabrata (Schott) Baill. (Euphorbiaceae). Dissertação de Mestrado. Universidade Federal do Rio de Janeiro, Rio de Janeiro.

Prance, G.T. 1994. The use of phytogeographic data for conservation planning. In: Forey, P.L.; Humphries, C.J. \& Vane-Wright, R.I. (eds.). Systematics and conservation evaluation. Systematics Association. Vol. 50. Clarendon Press, Oxford. Pp.145-163.

Prance, G.T. 1996. Islands in Amazonia. Philosophical Transactions of the Royal Society on London B 351: 823-833.

Punt, W. 1962. Pollen morphology of the Euphorbiaceae with special reference to taxonomy. Wentia 7: 1-116.

Radcliffe-Smith, A. 1987. Segregate families from the Euphorbiaceae. Botanical Journal of the Linnean Society 94: 47-66.

Radford, A.E.; Dickson, W.C.; Massey, J.R. \& Bell, C.R. 1974. Vascular plant systematic. Harper \& Row, New York. 891p.

Rizzini, C.T. 1977. Sistematização terminológica da folha. Rodriguésia 42: 103-125.

Rusby, H.H. 1920. Descriptions of three hundred new species of South American plants, with an index to previously published South American species by the same author. Published by the author, New York. 49p.

Sacramento, P.L. 1821. Nova plantarum genera en Brasilia. Denkschriften der Königlichen Academie der Wissenschaften zu München 7: 229-244.

Schreber J.C.D. 1791. Perula. Genera plantarum. Vol. 2. Pp.703-704.

Schomburgk, R. 1848. Versuch einer Fauna und Flora von Britisch - Guiana. Weber, Liepzig. 1260p.

Schott, H. 1827. Peridium. In: Sprengel, K.P.J. Systema Vegetabilium. $16^{\circ}$ ed. Vol. 24(2). Librariae Dieterichianae, Gottingae. P. 410.

Schranck, P. 1821. Observationes in P. Leandri de Sacramento. Nova genera plantarum. Denkschriften der Königlichen Academie der Wissenschaften zu München 7: 41-64.

Silva Alves, V. 1993. Notas sobre o gênero Pera Mutis (Euphorbiaceae). Anales del Jardín Botánico de Madrid 51: 151-153.

Souza, V.C. \& Lorenzi, H. 2008. Botânica sistemática: Guia ilustrado para identificação das famílias de
Angiospermas da flora brasileira, baseado em APG II. $2^{\mathrm{a}}$ ed. Instituto Plantarum, Nova Odessa.

Standley, P.C. 1930. Studies of American Plants. Field Museum of Natural History, Botanical Series 8: 3-73.

Standley, P.C. \& Steyermark, J.A. 1946. Euphorbiaceae - Pera. Flora of Guatemala. Fieldiana: Botany 24: 143-144.

Stevens, P. F. 2001, and onwards. Angiosperm Phylogeny Website. Version 9, June 2008. Disponível em $<$ http://www.mobot.org/MOBOT/research/ APweb/> Acesso em 15 Out 2008.

Tokuoka, T. \& Tobe, H. 2003. Ovules and seeds in Acalyphoideae (Euphorbiaceae): structure and systematic implications. Journal of Plant Research 116: 355-380.

Ule, E. 1908. Beiträge zur Flora von Bahia I. In: Engler, A. (ed.). Botanische Jahrbürcher fur Systematik, Pflanzengeschichte und Pflanzengeographie. 42: 191-238.

Urban, I. 1912. Nova genera et species V. In: Urban, I. (ed.). Fundamenta Florae Indiae Occidentalis. Symbolae Antillanae. Vol. 7. Fratres Borntraeger, Lipsiae. Pp. 151-432.

Webster, G.L. 1975. Conspectus of a new classification of the Euphorbiaceae. Taxon 24: 593-601.

Webster, G.L. 1987. The saga of the spurges: a review of classification and relationships in the Euphorbiales. Botanical Journal of the Linnean Society 94: 3-46.

Webster, G.L. 1994. Synopsis of the genera and suprageneric taxa of Euphorbiaceae. Annals of Missouri Botanical Garden 81: 33-144.

Webster, G.L.; Del-Arco-Aguilar, M.J. \& Smith, B.A. 1996. Systematic distribution of foliar trichomes types in Croton (Euphorbiaceae). Journal of Linnean Society of London 121: 41-57.

Weberling, F. 1992. Morphology of flowers and inflorescences. University Press, Cambridge. 405p.

Wurdack, K.J.; Hoffmann, P. \& Chase, M.W. 2005. Molecular phylogenetic analysis of uniovulate Euphorbiaceae (Euphorbiaceae sensu stricto) using plastid $r b c \mathrm{~L}$ and $t r n \mathrm{~L}-\mathrm{F}$ DNA sequences. American Journal of Botany 92: 1397-1420.

Wurdack, K.J. \& Davis, C.C. 2009. Malpighiales phylogenetics: gaining ground on one of the most recalcitrant clades in the Angiosperm tree of life. American Journal of Botany 96: 1551-1570. 